\title{
THE WORK OF GERHARD ROTH
}

\subsection{INTRODUCTION}

In the previous section the Graz literary phenomenon has been defined largely on the basis of practical literary activities at 'Forum Stadtpark' and the critical reception of works by leading participants in the Graz Group. The Graz Group itself has been shown to be an informal literary group or circle with a clearly delineated inner circle of relatively long standing. It has been argued that 'Grazer Literatur' exhibits a number of distinguishing characteristics which give it a special place in post-war German literature in general and Austrian literary tradition in particular. If the preceding discussion is to be of real literary-historical worth as an approach to Austrian literature of the past three decades, it must yield genuine insights into the development of individual Graz authors. The model established in Section One is applied here to an examination of the work of Gerhard Roth, a participant in the second wave of the 'Grazer Gruppe' in terms of his literary production, who also had early associations with the 'Studio der Jungen', establishing personal contacts with Bauer, the Graz painter Peter Pongratz, Handke, and Kolleritsch, before achieving his own literary breakthrough in 1972. The early development of Roth's literary career demonstrates the importance of the stimulus, and the critical receptiveness in West Germany, generated by 'Forum Stadtpark', manuskripte, and the initial critical breakthrough of the first wave of young Graz authors. From the publication of his first novel in 1972, he was identified by critics as one of the 'Grazer'. ${ }^{101}$ His acceptance in the early 1970 s by established participants in the Graz Group confirms the open and informal nature of this literary group formation. As an instance of 'Grazer Literatur', Roth's work exhibits a number of distinctive features. It also shares many of the general characteristics of 'Grazer Literatur' outlined in Section One. Roth's early work is genuinely avant-garde and experimental, displaying clear links to earlier Austrian and international literary experimentalism as well as to works by other Graz authors. A high level of linguistic self-consciousness is evident in his first published works which are quite literally 'Sprachspiele'. A critical attitude towards positivism, and therefore towards the objectivity of science, is an important departure point, which leads Roth to explore connections between science and aesthetics, a characteristic which also appears markedly in the work of Eisendle, albeit in a different guise. Roth's later work shows a desire to create positive links between avant-garde experimentalism and older narrative traditions. He gives more attention to the external social world, first

${ }^{101}$ See p. 49. 
in his two 'American' novels, Der große Horizont (1974) and Ein neuer Morgen (1976), then in Winterreise (1978), manifesting a desire to break with prevailing conditions in the Austria of the Second Republic. Later, in Der stille Ozean (1980), he redirects the focus towards Austria through a form of 'AntiHeimatliteratur'. Amongst the Graz authors, Roth shares with Handke the fascination with America and the eventual return to confront his feelings about Austria. ${ }^{102}$ The writing of 'Anti-Heimatliteratur' as a means of countering the persistence of negative German-national myth and ideology in the Second Republic is a distinctive oppositional feature of 'Grazer Literatur'. As the 'Anti-Heimatroman' it has served as a vehicle to explore and confront facts about society and culture in post-war Austria which many Austrians would rather forget or ignore. Roth's novel, Der stille Ozean, invites comparison with the contributions of other 'Grazer' to this genre including Jonke, Geometrischer Heimatroman; Handke, Wunschloses Unglück; and Gruber, Aus dem Leben Hödlmosers.

\subsection{ROTH'S EARLY LITERARY EXPERIMENTS IN GRAZ: 'EINE GESCHICHTSLOSE FORMALE LITERATUR'}

Gerhard Roth was born on 24 June 1942. He is a native of Graz and the son of a Graz physician. He attended the Lichtenfels Gymnasium. At nineteen he was already married and the father of a small daughter. Roth's first contact with the literary activities of 'Forum Stadtpark' occurred in 1962 when he was a young medical student at Carl Franzens University in Graz. He developed an early interest in writing and by 1962 had written a good deal of poetry and a number of prose sketches. ${ }^{103}$ At the Gymnasium he had gained some acting experience. Hearing from a friend that actors were urgently required by Forum Stadtpark's 'Studio der Jungen' for the first production of an experimental drama by Wolfgang Bauer, Roth volunteered his services. He played in two of Bauer's earliest one-act dramas, Der Schweinetransport and Maler und Farbe, both of which were strongly influenced by the Theater of the Absurd, and by the plays of Ionesco in particular. ${ }^{104}$ This was Roth's first meeting with Bauer. It was not

${ }^{102} \mathrm{~A}$ topic examined in the present writer's M. A. thesis, Three American Journeys - The Influence and Image of America in the Novels of Peter Handke and Gerhard Roth, University of Auckland, 1980.

${ }^{103}$ A poem of 1962 , Das Zimmer, introduces the Roth anthology, Menschen Bilder Marionetten: Prosa Kurzromane Stücke, (Frankfurt/M, 1979), pp. 11-12.

${ }^{104}$ In 1961 Bauer had seen a German production of Ionesco's Rhinoceros in Graz's Rittersaal which stimulated him to start writing for the theatre. See Gerhard Melzer, Wolfgang Bauer, (Königstein/Ts., 1981), p. 20. 
until the early 1970s that a close friendship developed between them. Roth felt confident during the rehearsals but on the opening night he suffered an acute attack of nerves. The production itself proved successful and Bauer's career as a dramatist was launched. Roth, however, discovered that he had no real interest in becoming an actor.

Roth is an exact contemporary of Bauer and Handke. In view of his early interest in writing and literature, it is all the more surprising to learn that during the nine years between his appearance in Bauer's first one-acters and the publication of Roth's 'Kurzroman' Künstel in manuskripte in 1971, he took no part in literary activities at 'Forum Stadtpark'. Indeed, he hardly ever attended its literary productions. As a husband and father with a strong sense of responsibility to his wife and family - by 1964 there were three children - Roth could ill-afford to adopt the carefree literary bohemianism practised in Graz at the time by Bauer, Falk, and Hengstler in particular. Until 1966, when increasing financial difficulties and an unwillingness to remain dependent any longer on help from his father compelled him to leave university, he continued as a full-time medical student. He then took a position as a computer programmer at the Graz medical data centre where he remained for the next ten years, first as a programmer and later as a head of department. It was only in 1976, at the age of thirty-four, that a firm contract with the Suhrkamp Verlag and a moderate income from his first two full-length novels, Der große Horizont and Ein neuer Morgen, finally enabled him to live as a full-time professional writer. Handke and Bauer, on the other hand, progressed directly from their university studies to professional literary careers.

In the early 1970s, Roth's literary career rapidly caught up with that of firstwave Graz authors like Handke and Bauer. In the 1960s, however, his literary development proceeded more slowly than that of his contemporaries. Despite his lack of contact with literary activities at 'Forum Stadtpark', Roth kept himself well-informed of the increasing tempo of cultural events in Graz, directly through friends and acquaintances like the painter, Peter Pongratz, and indirectly through his reading of manuskripte and reports appearing in the media. In 1965, while visiting Pongratz, he met Handke for the first time. Intellectually he felt greatly stimulated by the sense of energetic cultural renewal occurring in Graz. The ambience created by the unleashing of intense artistic activity in the city encouraged him to pursue his own literary efforts under circumstances which were often difficult and discouraging. In the pages of manuskripte he was exposed to work published by already more established contemporaries like Bauer, Frischmuth, Handke, Hoffer, and Hengstler, as well as to the work of other, somewhat older Austrian literary avant-gardists including Jandl, Mayröcker, Okopenko and the 'Wiener Gruppe'. As a source of general literary encouragement and of formal ideas for his early work, Roth's reading of this publication was important 'insofern als eben verschie- 
denste Romane und Erzählungen in verschiedenen Stilarten in den manuskripten immer vorabgedruckt waren und weil eben der Mut zur Moderne durch die Zeitschrift ins Haus gekommen ist. Das ist, man ist animiert worden, den Stil zu überprüfen und sich beim Schreiben weiterzuentwickeln' (Interview 2). It is precisely this 'Mut zur Moderne' which characterises this crucial phase in the literary development of the Second Republic. The courage to accept the challenge of the new, to find ways of tapping into avant-garde impulses as a means of overcoming oppressive cultural conservatism is a keynote of 'Grazer Literatur'. Particularly after 1965 , Roth began to read widely within the various avant-garde movements of this century - Expressionism, Futurism, Dada, Surrealism - including works by Aragon, Schwitters, Hülsenbeck, Peret, Klebnikov, Mayakowski, and the mysterious Daniel Charms. Roth complains that some of his critics seize on the association of members of the 'Wiener Gruppe' with the early years of 'Forum Stadtpark' and manuskripte as the major source of his links with avant-garde traditions in literature. This erroneous conclusion is based on a narrow, linear view of literary cause-and-effect and leads to misunderstandings in the placement and interpretation of Roth's early work. $\mathrm{He}$ had already discovered the work of a number of avant-garde authors quite independently of productions at 'Forum Stadtpark' and his reading of manuskripte. A large number of avant-garde texts became available in the $1960 \mathrm{~s}$ through West German publishing houses, whereas much of the work of the 'Wiener Gruppe' was published only towards the end of the decade. Roth certainly does not deny the stimulus which the particular synthesis of experimental ideas in the work of the 'Wiener Gruppe' brought to his own literary explorations. His reading of Konrad Bayer, for example, contributed towards the shaping of some of his later 'Kurzromane'. Overall, however, Roth's reception of works by the 'Wiener Gruppe' is only one of several links he made with experimental literature and should not be allowed to overshadow his independent interest in some of the same Modernist and avant-garde authors who had inspired the 'Wiener Gruppe' in the 1950s. Artists like Arp, Schwitters, Stramm, or Gertrude Stein were not the exclusive 'discoveries' of the 'Wiener Gruppe', even if they were the first Austrian authors in the immediate post-war years to take an interest in the work of such pioneering avantgarde writers.

Roth's protracted involvement with his medical studies, with the ordinary world of work and family concerns during the 1960s, made considerable demands on his time and attention and undoubtedly delayed the purely technical development of his literary work. In the long run, what he learned during these years proved to be of great benefit to his development as an author. In addition to a wealth of personal experience, Roth gained a broad knowledge of the natural sciences, of the new information technology, and insights into the society of the Austrian Second Republic at a level of greater 
personal involvement than contemporaries who had already attained the status of 'freier Schriftsteller'. This period contributed much to the formation of recurrent thematic interests which distinguish his literary work from that of other Graz authors. A portrait of Roth penned by Greiner in 1976 reflects this distinctive aspect of Roth's character and experience:

Damals in Graz ... fiel er mir dadurch auf, daß er nicht auffiel: Während alle anderen Schriftsteller wie Schriftsteller aussahen, sich durch irgendein hervorstechendes Merkmal, durch lange Haare oder rauschenden Bart, durch besonders bequeme Kleidung oder ungezwungenes Benehmen bewußt oder unbewußt von jenem Durchschnittstyp abhoben, der die Straßen und Büros bevölkert, schien Gerhard Roth auf solche Unterscheidung keinen Wert zu legen. Im Gegenteil: sein gepflegtes und zugleich unauffälliges Äußere, sein selbstsicheres und zugleich zurückhaltendes Auftreten ließen eher an einen höheren Bankangestellten denken als an jenen Schriftsteller, der mit experimentellen Romanen ... beängstigende Protokolle pathologischer Geisteszustände geschrieben hatte. ${ }^{105}$

Roth himself takes a certain pride in the fact that, unlike many of his contemporaries, he spent many years working as an ordinary employee in the community: 'Ich glaube nicht, daß ich außerhalb der Gesellschaft stehe. Im Gegenteil glaube ich, daß ich sehr intensiv an der Welt teilnehme. Ich habe zehn Jahre im Rechenzentrum gearbeitet. Ich war zuerst Operator und habe am Schluß eine Abteilung mit dreißig Leuten gehabt' (Interview 1). The work habits which Roth acquired during this time - precise observation and careful organisation of complex materials, regularity and efficiency of effort - proved invaluable for his later literary production. More important, especially for the later novels, was the fact that he was able to be at ease in the company of ordinary people and was as capable of entering into their concerns with a sympathy based on personal understanding, as he was of understanding the particular problems and dilemmas he and other authors faced as members of a more specialised literary community.

A strong interest in imaginative writing emerged early in Roth's life and remained a constant factor throughout the 1960 s, even when circumstances forced him to engage in other activities:

Ich glaube, ich war immer ein Schriftsteller ohne es zu wissen, zunächst, in der Kindheit. Zum Beispiel, habe ich nach dem Krieg Bücher gemacht als Kind - selbst gezeichnet. Meine Großmutter hat sie zusammengenäht. Ich habe mir eine kleine Bibliothek gemacht, habe Geschichten geschrieben und

${ }^{105}$ Der Tod des Nachsommers, p. 158. 
es ist eigentlich so fortgegangen bis zu meinem zwölften Lebensjahr. Dann habe ich viele Jahre Tagebuch geführt. Ich habe auch natürlich Gedichte gemacht: damals hatte ich ein ganz dickes Heft davon (Interview 1).

At the computer centre Roth often worked on the night-shift. He spent much of his free time writing. In this way he produced all his literary and journalistic work up to 1976, including Ein neuer Morgen. As a child, writing stories had been more important to him than reading them. Reading was a pastime which he initially regarded as difficult and not especially interesting: 'Aber ich las nicht oft. Einige Jahre später erst packte mich so etwas wie eine Leidenschaft: Es waren bunte Comic-Hefte: Tarzan, Akim, Prinz Eisenherz, Micky Maus und Donald Duck, die damals bei vielen Eltern verpönt waren und darum noch mit dem Ruch des Verbotenen behaftet, doppeltes Interesse hervorriefen'. ${ }^{106}$ It was only towards the end of the 1950s that Roth's interest in reading literature emerged in earnest:.

Zwei, drei Jahre später verfiel ich tatsächlich dem Lesen, das seither zu einer Art Droge für mich geworden ist: Ich las so viele Schriftsteller, die mich beeindruckten, daß ich immer schwerer meine eigene Sprache fand ... Ich wollte schreiben wie Rilke und Trakl, wie Hemingway, wie Dostojewski und Hamsun, dann wie Borchert und Benn, Mann und Kafka ... ich lief tatsächlich Gefahr, mich mit dem Lesen selbst zu zerstören ... Ich las alle 'Jugendbücher' im Nachhinein, zum Teil als ich schon über 20 war: Moby Dick und Robinson Crusoe, Tom Sawyer und Huckleberry Finn, den Lederstrumpf und den Seewolf, und ich lese diese Bücher auch heute gerne ... ${ }^{107}$

Roth's early reading embraced what Heißenbüttel referred to somewhat disparagingly in connection with Handke's formative reading as the literature of 'Bildungskonventionen' - a representative sampling of the canon of recent Western literary tradition. His reading of the 'Stammväter und -mütter der Moderne' followed later. ${ }^{108}$ Writers like Knut Hamsun, Gottfried Benn, and Henry Miller left distinct traces on some of Roth's earliest published poems and stories.

Two factors which were decisive in the development of Roth's interest in literature, both as a writer and as a reader, were the frequent bouts of illness he suffered from early childhood onwards and the acute sense of being somehow different which has accompanied him as far back as he can remember. In spite

${ }^{106}$ Erste Lese-Erlebnisse, edited by Siegfried Unseld, (Frankfurt/M, 1975), 'Gerhard Roth' pp. 119-121 (p. 120).

${ }^{107}$ Unseld, p. 120.

${ }^{108}$ See Heißenbüttel, 'Peter Handke', Text + Kritik. No. 24 (Munich, 1969) pp. 14-20 (p. 19). 
of a strong desire for acceptance, Roth found himself repeatedly unable to conform. Although outwardly an apt pupil, at school he experienced recurrent misery at being 'abandoned' to a system of instruction which he experienced as alien and repressive. The accounts of other Graz authors of their schooldays reinforce the impression of the unnecessarily severe and narrow education many of their generation received from a strict Roman Catholic school system. ${ }^{109}$ In the essay 'Die Schule brennt' (1975), Roth recalls that his strongest memory of school is fear: 'Man wurde bei diesem und jenem ERTAPPT, irgend etwas wurde einem NACHGEWIESEN, man wurde BEURTEILT, GEPRÜFT, AUSGEFRAGT es gab KARZER, und Schul-HAFT ( $M B M$, pp. 100-102, (p. 101). See Key). He elaborates on this and his feeling of 'Andersartigkeit' in an interview:

Ich sehe mich nicht anders dadurch, weil ich ein Schriftsteller bin, sondern ich wäre auch als Operator im Rechenzentrum, wenn ich geblieben wäre, eben anders gewesen. Und diese Andersartigkeit habe ich immer gelitten. Ich bin mir von der ersten Stunde in der Schule dumm vorgekommen und ausgeliefert. In der Schule bin ich mit dreizehn oder vierzehn Jahren von der Klasse gequält worden: es ist über Monate gegangen. Mir tun die Kinder leid, die in die Schule gehen müssen. Es geht nicht anders - das sehe ich ein - aber ich bedaure sie zutiefst und ich verstehe jedes Kind, das Selbstmord gemacht hat in der Schule (Interview 1).

Roth frequently came into conflict with his father, who was deeply conservative and a disciplinarian. In the later stages of his adolescence reading came to provide Roth with an important source of solace and escape: 'das Lesen half mir zugleich über Krankheiten und Depressionen hinweg, über Phasen der Kontaktlosigkeit und manchmal auch der Einsamkeit' ${ }^{110}$

\subsubsection{The Sense of Displacement}

The sense of displacement, the feeling of being somehow not entirely at home in society and the world at large, provides the guiding impulse for much of Roth's work. He shares with other participants in the Graz Group a distrust of

\footnotetext{
${ }^{109}$ See, for example, Barbara Frischmuth's largely autobiographical novel Die Klosterschule (1968), Handke's observations in 'Ein autobiographischer Essay' (Ich bin ein Bewohner des Elfenbeinturms pp. 11-16) and 'Persönliche Bemerkungen zum Jubiläum der Republik' (Das Ende des Flanierens, pp. 56-59), Kolleritsch's novel Die grüne Seite (1974), and, satirically reflected, Gruber's Im Namen des Vaters (1979).

${ }^{110}$ Unseld, p. 120.
} 
all ideological approaches to the human condition and an aversion to intellectual system-building of any kind. This attitude makes him unwilling to describe his sense of displacement using such terms as 'Verfremdung' (alienation) or 'Entfremdung' (estrangement) which suggest stereotyped concepts strongly linked to particular philosophical systems. For Roth, as for Handke, 'das Wahre ist das Feine': ${ }^{111}$ precise observation and description of experience must take precedence over pre-existing systems of interpretation. Avoiding the use of ideologically loaded terms, Roth defines the disturbing sense of difference, of not belonging, by means of a play on the German word 'Verrücktheit' (madness/craziness). He draws on the root-meaning of the adjective 'verrückt' (mad/crazy) which signifies that the subject is somehow 'ver-rüickt' (displaced):

Unter 'Verrücktheit' verstehe ich keinen physiologischen Zustand sondern, daß ich eben 'ver-rückt' bin innerhalb der Gesellschaft, nicht an einem Platz, wo jemand hingehört. Und dieses Gefühl, das habe ich schon eigentlich immer gehabt, ein Gefühl der Fremdheit, nur weil ich lange Zeit eher bewußt Gefühle darüber gehabt, eher Schuldgefühle, daß das so ist (Interview 1).

In a parallel context elsewhere, Roth uses the term 'Verschobenheit' which as 'displacement' in English carries the least association with any philosophical school. His thematic preoccupation with what might be termed 'the psychopathology of displacement' cannot be dismissed as the product of a lateadolescent self-identification as a romantic 'outsider' figure. It cannot be categorised as a merely fashionable embrace of the 'existential alienation' which, through the reception of Camus and Sartre, became popular amongst intellectuals and artists in the 1950s and early 1960s, although Roth was familiar with their work. Nor is it a 'phase' through which he passed before moving on to consider themes of 'more immediate social and political relevance'. Rather this sense of displacement is the fundamental experiential premise from which he has repeatedly set out to explore and express the human condition. In such instances we see the effects of the effort of Roth and other 'Grazer' to put into practice some of the implications of the 'Sprachkritik'. The entertainment of doubts about language and our ability to 'know' can, of course, be seen as an 'anti-system' as Bauer reminds us, but it is more productive to see this resistance to classification as part of the oppositional character of 'Grazer Literatur' and, in effect, as a plea for open-mindedness.

All of Roth's protagonists from the schizophrenic, einstein, to Ascher, the doctor seeking to escape from the consequences of a malpractice suit in Der

"'Roth used this phrase when describing to the present writer Handke's approach to the links between language and reality. Notes to Interview 1, October 1980. 
stille Ozean, are 'displaced persons' whose behaviour is symptomatic of the sense of being displaced 'innerhalb der Gesellschaft'. A definition of 'Verrückter' given by Eisendle as 'einer, der von der Stelle der Norm entrückt ist' ${ }^{112}$ helps to clarify the social assumption behind this notion. In a repressive cultural climate, any departure from the norm constitutes displacement and is frequently accompanied by guilt and recrimination. At the same time, Roth accepts that there is no way of breaking out of society: there is only the hope of a shift of values, attacking petrified forms of normality and opening the way for a re-evaluation of what is blindly categorised as 'ver-rückt'.

\subsubsection{Science and Aesthetics}

In the course of his medical studies, Roth was exposed to a number of ideas and experiences which were later to become part of his literary aesthetics. Contemplation of life as it is revealed through the analytical models of the physical and biological sciences augmented rather than diminished his growing private sense of the strangeness and mystery just below the conventional surface of everyday existence. A comparable suspicion of surface appearances - an element of the general scepticism about consensus reality evident in 'Grazer Literatur' - was induced in Handke in the course of his legal studies and in Eisendle through his work as an experimental psychologist. Kolleritsch, who wrote his doctoral dissertation on 'Eigentlichkeit und Uneigentlichkeit' in Heidegger's philosophy, arrived there via epistemology and ontology. Roth gained a precise and detailed understanding of the ways in which 'normal' states of consciousness depend upon countless minute energy exchanges which the slightest chemical or electrical imbalance can throw into disarray. Like Hans Castorp in the 'Research' chapter of Mann's Der Zauberberg, he began to appreciate the subtle and delicate interrelationship between chaos and order in the intricate cellular processes which regulate life and death in the human organism. In the dissecting room and operating theatre, he experienced the often bizarre and sometimes grim realities unmasked by the probings of science into natural organic processes. He felt a sense of repulsion at the practices of surgery and pathology which soon turned his interest away from physical medicine to psychiatry. On the moral side, he conceived an intense dislike of the coldly impersonal attitude to patients fostered by institutionalised medicine and witnessed the social inequality practiced within the state hospital system where the well-off were favoured while the poor were often humiliated. Roth's earliest published prose piece, a short, realistically narrated sketch

\footnotetext{
${ }^{112}$ Exil oder der braune Salon, (Salzburg, 1977). This quotation from the Rowohlt edition, (Reinbek, 1979), p. 36.
} 
entitled 'Das Rendezvous' 113 , depicts the emotional suffering of a young woman who has undergone a mastectomy. She flees in panic from a lover when she cannot bring herself to admit this fact: 'sie sah die vielen Ärzte ihres Lebens vor sich, die nickelblitzenden, weißen Röntgenapparate, unter denen ihr ausgemergelter, brustloser Körper gelegen war'. Already, in this short story it is clear that Roth's sympathies are on the side of the patient as an instance of suffering humanity and are directed against unfeeling forms of 'objectivity and detachment' created by the egotistical assertion of professionalism and expertise. Criticism of Austrian medical and psychiatric institutional practices is a recurrent theme in Roth's literary and journalistic work. ${ }^{114}$

While still a medical student and some time before he examined the earlier German literary sources on the subject, Roth began to explore some of the links between the world of science and the realm of aesthetics. In an early essay written for a student magazine on the work of the American novelist, Henry Miller, Roth quotes with approval a remark made by Chekov, who was also a physician, on the objectivity necessary to an author who desires to approach life in a realistic fashion. ${ }^{115}$ Such a writer, says Chekov, must regard the world like an analytical chemist and describe, without moral queasiness or prurience, everything which presents itself to his attention. Roth found such courageous openness of mind exemplified in Miller's unstinting, taboo-breaking quest for truth. In the work of Büchner, Roth found much that helped to shape his approach in this connection. Given the general revival of interest in Büchner which was taking place at the time, it is not in itself surprising that a writer of Roth's generation should have read his work. But for Roth with his scientific background and interest in pursuing a related aesthetic, Büchner's work held a particular fascination. Late in 1973, Roth made clear the relevance of Büchner to his early work:

Sehen Sie, ich bin bei meinen Arbeiten bisher von Büchner beeinflußt gewesen. Auch bei Büchner, zum Beispiel im Woyzek, gibt es eine Ästhetik, die aus der Kombination eines Sprech- oder Erzählstils mit Ausdrücken aus dem naturwissenschaftlichen Sprachbereich entsteht. Dadurch, daß ich mich

${ }^{113}$ 'Das Rendezvous', Impuls - kritische Zeitschrift für Studenten (Graz), April/May/June Issue 1966, p. 10.

${ }^{114}$ See, for example, 'langsam scheiden: Ein Besuch bei Alexander', Frankfurter Allgemeine Zeitung 30 October 1976, an article which no Austrian newspaper would publish (reproduced in $M B M$, pp. 126-134); 'Wenn es Politikern so ginge...: Rückblick auf einige Spitalzustände', Kleine Zeitung (Graz), 19 March 1978; 'Eismeer des Schweigens: Ernst Herbeck - "Alexander" - Ausgewählte Texte 1961-1981', Die Zeit, 14 January 1983, p. 36. The essay, 'langsam scheiden', was included in Alexanders poetische Texte, edited by Leo Navratil, (Munich, 1977), pp. 193-199.

115،Über Henry Miller', Impuls - kritische Zeitschrift für Studenten (Graz), October/November/December Issue 1966, pp. 16-19. 
mit Naturwissenschaften beschäftigt habe, konnte ich meine Vorstellungen erst überhaupt verwirklichen. ${ }^{116}$

From Dostoyevsky, and more particularly, from his intensive reading of Hamsun, Roth learned that borderline and decidedly pathological states of mind contained a wealth of fascinating and potentially aesthetic moments. A little later, in the work of Gottfried Benn he came across similar ideas from a German Modernist perspective.

Of particular significance for the development of the three early 'Kurzromane', die autobiographie des albert einstein, Künstel, and Der Wille zur Krankheit, was his discovery through his university reading of standard texts on mental illness, of the literature and art of schizophrenia. In the autumn of 1965 , Roth became acquainted with the young Graz painter and graphic artist, Peter Pongratz (b. 1940). Pongratz was deriving much inspiration for his work from schizophrenic art. Roth provided him with psychiatric texts on the illness. Through Pongratz Roth in turn discovered the work of Prinzhorn and other specialists on the visual manifestations of schizophrenia, including Lange-Eichbaum. Inevitably Roth came to read the studies of the Austrian psychiatrist, Leo Navratil, whose two volumes Schizophrenie und Sprache and Schizophrenie und Kunst, reached a surprisingly varied public in West Germany and Austria in the 1960s and 1970s. ${ }^{117}$ Through Navratil, Roth later came to meet the schizophrenic poet, Ernst Herbeck, in 1976, about whom he wrote the essay, 'langsam scheiden: Ein Besuch bei Alexander'. (See Note 114). Reading Navratil and others, Roth began to realise that both the rational techniques of science and the irrational distortions of the world which occurred in certain types of mental illness could present images of a world so strange that they tended to subvert the 'rules' of consensus reality.

In later interviews and articles, Roth discussed the effects of his scientific training on the formation of his initial literary strategy. The subversive appropriation of descriptive techniques and analytic models from science will be examined in detail in the context of the 'Kurzromane' themselves. A general summary of his aesthetic position with regard to the rift which positivist science has opened up in our experience of the relationship between nature and

${ }^{116}$ Jürg Laederach, 'Laederach mit Roth über Roth', Basler Nachrichten, 24 November 1973.

${ }^{117}$ Navratil, a professor of psychiatric medicine and chief consultant at the 'Niederösterreichische Landeskrankenhaus für Psychiatrie and Neurologie' in Klosterneuburg, is also a member of the 'Grazer Autorenversammlung'. He has edited a number of collections of writings by schizophrenics, including Weltbilder, (Salzburg, 1970) with Gert Jonke, and Ernst Herbeck: "Alexander" - Ausgewählte Texte 19611981, (Salzburg, 1982). Roth reviewed this volume in Die Zeit, 14 January 1983 - see Note 114. 
culture is given in an essay of 1973, 'Technik des Naturempfindens gegen Kunst der Technik' ( $M B M$, pp. 49-51). Roth argues that the growth of technological societies has made it increasingly difficult for us to experience directly the sublime harmony between man and nature advocated in the nineteenth century by Stifter, or even the disquieting ambivalence of a natural order which in the darker strain of European romanticism exemplified by Büchner, infuses moments of calm and tranquility with the threat of terror and destruction. On the positive side, science has increased enormously our ability to experience nature optically and acoustically through the many technological extensions of our vision and hearing. Despite the often extraordinary beauty and complexity of the images yielded, for example, by the techniques of deepspace photography or electron-microscopy, Roth observes that the longing of humankind for direct experience of 'original nature' ('die Sehnsucht des Menschen nach der "ursprünglichen” Natur’) persists undiminished:

Auch wenn sich diese Natur in der Wissenschaft als ein nahezu okkultes Spiel von winzigen Teilchen, von Regelprozessen und chemischen Reaktionen darstellt, will sich der Mensch offensichtlich das ganzheitliche Gefühl der Naturerfahrung bewahren, indem er die Natur zu einem feindlichen Gegenpol idealisiert. Die moderne Kunst kann diesen Zwiespalt jedoch nicht in dieser Form überwinden, sondern muß die neuen Informationen integrieren ( $M B M$, p. 51).

As one example of the way in which art can integrate scientific findings into an aesthetic system, Roth cites Anton von Webern's musical celebration in certain of his string quartets of the miniature worlds revealed by the microscope. Significantly for Austrian literary tradition, he concludes the essay with a quotation from Stifter's novel Der Nachsommer (1857):

Der Mensch stört leider durch zu starke Einwirkungen, die er auf die Nerven macht, das feine Leben derselben, und sie sprechen $\mathrm{zu}$ ihm nicht mehr so deutlich, als sie sonst wohl könnten. Auch hat ihm die Natur etwas viel Höheres zum Ersatz gegeben, den Verstand und die Vernunft, wodurch er sich zu helfen und sich seine Stellung zu geben vermag ( $M B M$, p. 51).

From his twentieth-century vantage point, Roth shows himself fully aware of the limitations of Stifter's 'gentle law' and 'harmonious concord' as a means of restoring the lost unity of nature and culture. It is characteristic of 'Grazer Literatur' that Roth should break with regressive aspects of Austrian tradition as they are manifested in Stifter's work. Stifter's personal philosophy of a quasi-religious reconciliation between man and nature is largely unacceptable to him. He views it as 'Der verzweifelte Versuch eines im Innern chaotischen 
Menschen, sich an der Ordnung, an der Naturgesetzlichkeit, der Schönheit festzuklammern' ( $M B M$, p. 49). But in Stifter's aesthetic programme as it is expressed in Nachsommer and the 'Vorrede' to Bunte Steine, Roth recognised the workings of a mind which, like his own, was grappling with ways of integrating science with the nexus of art and the need for aesthetic experience.

Roth's earliest experimental texts constitute, in part, a realisation of one set of ideas first put forward in Austrian literature by Stifter in 1852:

Wenn wir, so wie wir für das Licht die Augen haben, auch für die Elektrizität und den aus ihr kommenden Magnetismus ein Sinneswerkzeug hätten, welche große Welt, welche Fülle von unermeßlichen Erscheinungen würde uns da aufgetan sein. Wenn wir aber auch dieses leibliche Auge nicht haben, so haben wir dafür das geistige der Wissenschaft, und diese lehrt uns, daß die elektrische und magnetische Kraft auf einem ungeheueren Schauplatz wirke, daß sie auf der ganzen Erde und durch den ganzen Himmel verbreitet sei... ${ }^{118}$

The astonishingly rapid advance of science and technology in the century since Stifter made these observations has added a vast optical dimension to the 'intellectual eye of science'. The range of the physical eye has been artificially extended to the point where light, electricity, and magnetism have in a very real sense become 'visible'. Roth became interested not just in the dazzling play of such physical phenomena in themselves, but in the effects of this new scientific consciousness on the sense of personal identity and the perception of reality.

Roth describes the work which he produced between 1966 and the beginning of 1973 - the five 'Kurzromane': die autobiographie des albert einstein, Künstel, Der Ausbruch des Ersten Weltkriegs, How to be a detective, and the drama, Lichtenberg - as the products of his subjektive Phase: 'Am Anfang war die Sprache für mich ein sehr subjektiv betrachtetes Instrument und ich habe sie angewandt, um meine inneren Schwierigkeiten darzustellen' (Interview 1). He regarded these early experiments as 'mehr oder weniger Erprobungen meiner Verrücktheit' - literary explorations of his sense of displacement.

${ }^{118 ، V o r r e d e ' ~ t o ~ ' B u n t e ~ S t e i n e ' ~ i n ~ G r a n i t, ~(S t u t t g a r t, ~ 1966), ~ p p . ~ 5-6 . ~}$ 


\subsubsection{From Aufzeichnungen eines überflüssigen Menschen to die autobio- graphie des albert einstein}

In terms of literary technique - the evolution of a complex narrative perspective, descriptive skill, and sheer verbal sophistication - Roth travelled a relatively long way from the chapter of his uncompleted first novel, Aufzeichnungen eines überflüssigen Menschen, which appeared in impuls, the Graz University student magazine, in 1967, to the publication of the work which grew out of it, the 'Kurzroman', die autobiographie des albert einstein, in 1972. In tracing the development of einstein, a work both formally and thematically much more avant-garde than the project from which it sprang, much can be learned about Roth's reactions to experimental tendencies in the evolving literature of Graz and its associated 'Mut zur Moderne'. Much is also revealed about the thematic preoccupations which render distinctive the literary production of this participant in the Graz literary circle. einstein is therefore examined here in greater detail than the remaining early 'Kurzromane'. In the chapter of Aufzeichnungen published in 1967, a young Austrian bearing an unmistakable resemblance to the delirious and defiantly eccentric protagonist of Knut Hamsun's first novel, Hunger (1890), is mysteriously pursued through the streets of a modern Stockholm by an equally eccentric, trembling, and in the confused mind of the hero, decidedly malevolent dog. Several attempts to elude his canine pursuer lead to a final confrontation in a crowded city park. The chapter ends with a triumphant, but the reader suspects, temporary victory of man over dog. In these eighteen pages the phantasmagoric world of Roth's early work is captured in miniature. Links to the style of later works from Circus Saluti (1981) onwards are also apparent. In this first-person narrative written within the conventions of nineteenth-century realism, Roth displays a growing sense of literary craftsmanship - his already considerable ability to control narrative pace and flow and to handle dialogue and inner monologue. Certain characteristic thematic elements expanded in einstein and the later 'Kurzromane', are already essentially present in this novel fragment. The narrator is estranged from his fellow citizens, an outsider figure, somewhat neurotic, compulsive in speech and behaviour. He has a feverish, at times violent imagination. He shows little ability to respond openly to the needs and feelings of others and lives instead in a private inner world remote from ordinary concerns. Delivered up to the flux of his own immediate experience, he makes connections between events which indicate that for him society and the universe do not function according to any known pattern or system of belief. The sense of normality has been drained from the familiar everyday world with the result that each moment becomes a new venture into the unknown territory of contingent events. The narrator's morbid fear that the dog might prove rabid carries with it Roth's incipient fascination with the idea that 
the world in which we live, the world of nature, of society, the human organism itself, is one in which life is as capable of chaos and destruction as it is of order. Here a theme is introduced which Roth builds on in later novels, as, for example, in Der stille Ozean (1980), where it occurs as the fear of an outbreak of rabies which besets the local farmers resulting in the irrational slaughter of foxes and other animals even remotely suspected of harbouring the disease. Roth freely admits that the style of Aufzeichnungen owed much to Hamsun whose works he was reading avidly at the time. During the summer vacation of 1965, Roth had visited Sweden. In Aufzeichnungen, his experiences in Stockholm are filtered through this reading and reveal a strong identification with the moods and attitudes of the Norwegian author's solitary heroes and their psycho-spiritual adventures. As is the case with many young writers searching for their own literary voice, Roth was highly susceptible to such influences.

Roth had begun work on Aufzeichnungen in 1965. By 1967, the draft filled three large notebooks in somewhat cramped handwriting. Convinced that he had written something of worth, Roth typed up a dozen sides of the manuscript and submitted them to Kolleritsch for publication in manuskripte. The chapter was rejected. The editorial policy of manuskripte was governed by Kolleritsch's highly strategic efforts to foster an alternative Austrian literary tradition. Although the magazine's approach to literature was essentially pluralistic and desired to represent 'die Vielfalt der möglichen neuen Schreibformen' ( $m$ 12/1964, 'marginalie'), Kolleritsch tended to prefer texts which reflected the growth of a linguistically self-conscious literature. Aufzeichnungen was stylistically within the conventions of nineteenth-century realism: it was not the language of the text which was unconventional but the thoughts and attitudes it conveyed. The three issues of manuskripte published in 1967 include contributions from Artmann, Bauer, Bense, Falk, Handke, and Wiener, as well as texts by Hans Arp, Raoul Hausmann, and Kurt Schwitters. There is a clear preference for works of a more avant-garde experimentalism than the more-or-less realistic portrayal of bizarre events offered in Roth's narrative. In 1964 Kolleritsch had specifically excluded from publication in manuskripte works representing a 'Realismus, der eine so naiv wie möglich gefaßte Realität so naiv wie möglich zur Sprache bringt' (m 12/1964, 'marginalie'). Roth's immediate reaction to Kolleritsch's rejection slip was to be overcome by shame at the image he had entertained of himself as a writer. After 1970 Kolleritsch would alter his approach to the question of realism although the emphasis on linguistic self-consciousness remained in force. For Roth in the meantime, all was not lost. The chapter of Aufzeichnungen was accepted for publication in impuls and appeared with illustrations by Pongratz. Roth had made initial contact with Kolleritsch and eventually in 1971 his first contribution to manuskripte would appear. After his first experimental phase, when in 1973 Roth 
adopted forms of narration closer to realist conventions, he realised that he had gained much from this early apprenticeship to a more traditional narrative form.

The event which set in motion the process of re-thinking and re-writing the materials he had embodied in Aufzeichnungen, transforming them between 1967 and 1970 into what became einstein, has about it the character of a lucky accident. One night in 1967, a water pipe burst in Roth's apartment, flooding his writing-desk and saturating his notebooks so that, after drying out, only parts of the manuscript remained legible. At first, he attempted to reconstruct the text, but the fragmentary nature of what had survived led him to see new connections in the material and forced on him a new and deliberate method of narrative construction which had nothing to do with any theorising about the novel form. Typing, rather than hand-copying the remaining fragments, he also found that he gained a more objective view of the work. In Aufzeichnungen, Roth had set out to confront his own sense of 'Andersartigkeit', 'das Gefühl der Fremdheit', and to examine feelings of guilt induced by this condition. In the anarchic-poetic impulse of Hamsun's prose he thought he had found a model for this exploration, but he was now made to see that it was a literary mould which set a limiting and unwanted historical stamp on his writing. He sought instead to develop a narrative strategy and a form of language which would enable him to explore the ramifications of a radical sense of displacement unhindered by the compulsion to classify and interpret experience in terms of the repressive cultural norms maintained by Graz's conservative 'Kulturbürger', or the unexamined rationality of the positivist sciences in which he had been trained. In his professional studies Roth had already encountered studies of disturbed perception. Stimulated by his discussions with Pongratz, Roth began to examine texts on the art and writings of schizophrenics with intense interest. In them he glimpsed the seeds of a narrative strategy which would allow him to explore and express borderline states of consciousness as literary representations of his sense of 'Ver-rücktheit'. In spite of Susan Sontag's protest on behalf of the afflicted that 'illness is not a metaphor, and that the most truthful way of regarding illness - and the healthiest way of being ill - is one most purified of and resistant to metaphorical thinking', ${ }^{119}$ the psychopathology of schizophrenia, along with tuberculosis, cancer, and, most recently, Aids, has acted as a primary source for metaphor hunters in the twentieth century. It provided Roth with a complex and intriguingly ambiguous metaphorical structure for his first concerted attempt to spring the linguistic boundaries of his own cultural repression. The idea of the psyche divided into ceaselessly warring camps of apparently irreconcilable desires and irresistible impulses and the often bizarre symptoms of this disease

${ }^{119}$ S. S., Illness as Metaphor, (New York, 1977), p. 3. 
- the collapsing sense of personal identity, the loss of reality resulting from a radical displacement of feelings, the dulling of affect reactions, the accompanying auditory and visual hallucinations and other perceptual disturbances have suggested to artists and intellectuals a host of parallels illustrative of the predicament of Western civilisation. The attractiveness of mental illness in general, and of schizophrenia in particular, as a metaphor among artists and critics of culture in this century, was much in evidence in the 1960s, when disenchantment with existing cultural and political values came to an explosive peak in many Western societies. The feeling that we live in a culture which shows many signs of being divided against itself was widespread. This is evidenced by the popularity of the critiques advanced by such thinkers as Michel Foucault, Gilles Deleuze, Félix Guattari and R. D. Laing. As Botho Strauß observed in an essay written for Theater Heute in 1970:

Zur Zeit ist das Irresein, so scheint es, eine gewöhnliche Metapher für das Befinden des Individuums überhaupt, für die internierten Kräfte seiner Fantasie, inmitten einer Gesellschaft, welche nur zur Raison bringen versteht, welche im Namen der Vernunft eine perverse Unterdrückungsherrschaft ausuibt. ${ }^{120}$

A rising interest in the 'Vorzugsthema Wahnsinn' is a characteristic of much new German literature of the 1970s. Referring to Foucault's comment on this renewed literary interest in the theme of madness - 'Ce n'est pas le vieux thème platonicien du délire inspire. C'est la marque d'une nouvelle expérience du langage et des choses' ${ }^{121}$ - the Swiss author and psychiatrist, Walter Vogt, opposes the notion that this represents a merely fashionable revival of the romantic cliché of the inspired madness of the creative artist. For Foucault, Vogt and Strauß, amongst others, the madness has become part of a social environment in which the writing of literature, earlier regarded as one of the peaks of cultural achievement, has become caught up in a shift of values such that it is frequently regarded not only as economically unproductive but as an aberration from social norms. Given this situation, Vogt concludes that anyone setting out to produce serious works of literature in such a society is by definition to some extent 'verrückt'. He notes also that as scientific medicine loses its certainty about the concept of schizophrenia, the popular journalistic notion of the disease triumphs: "eben, gerade weil er die ursprüngliche "Be-

\footnotetext{
${ }^{120}$ 'Versuch ästhetische und politische Ereignisse zusammenzudenken', Theater Heute, October 1970, pp. 61-68 (p. 68).

${ }^{121}$ W. V., 'Die Schizophrenie der Kunst: Eine Rede' in Literatur und Schizophrenie: Theorie und Interpretationen eines Grenzgebiets, edited by Winifred Kudzus, (Munich, 1977), pp. 164-175 (p. 165). The quotation is from Foucault's Les mots et les choses, p. 63.
} 
wußtseinsspaltung" ganz naiv meint und damit eben doch Wesentliches aussagt zu unserer Situation. Man darf vermuten, daß so wie das 19. Jahrhundert schließlich sein Herz in der Neurose wiederfand, unsere Epoche die Strukturen ihres Denkens und Handelns, ihre Visionen und Ängste wiederfinden wird in der Großen Schizophrenie (Navratil)' ${ }^{122}$

What Roth required as a narrator was an outsider figure who would enable him to explore in a highly subjective and imaginative way the effects of letting go the conceptual sheet-anchors which in the external world served to stabilize the intellectual, social, and cultural norms of the Austrian Second Republic. Roth shared with other young 'Grazer' the feeling that this new post-war Austrian state was becoming increasingly bureaucratic, technocratic, and obsessed with consumerism. What attracted him to the idea of a schizophrenic narrative figure was not a matter of accident or fashion. He realised in a manner symptomatic of the intellectual climate of the late 1960 s, that the world of the schizophrenic can be read as a distorted mirror-image of a more general social and psychological predicament. In the anarchic and wildly productive verbal and visual creations of schizophrenia with its blatant disregard for the logic and rationality which bind together the conventional world, Roth saw a fictional base for an attack on the values of 'die verwaltete Welt'. The schizophrenic is considered mad and is isolated forcibly from the rest of society because of a radical alteration in his perception of himself and the world. Roth now posed the intriguing question as to whether the experiences of a citizen who internalised and literally lived out abstruse gleanings from the wealth of information about ourselves and the universe which science has accumulated, might not in many ways resemble those of a schizophrenic:

In meinem Fall hat sich z. B. der Einbruch der Wissenschaft in das alltägliche Leben in der Form ausgewirkt, daß ich in meinem ersten Roman, die autobiographie des albert einstein, die Hauptfigur den Raster des naturwissenschaftlichen Denkens auf alle Wahrnehmungen und Gedanken legen lasse, wodurch - zunächst rein sprachlich - künstliche, zerebrale 'Paradiese' entstehen. D. h. also, daß die Sprache mit dem veränderten Wahrnehmungsprozeß konform geht, ein Vorgang, der im Fall von Schizophrenie $\mathrm{zu}$ beobachten ist. ${ }^{123}$

Writing and re-writing some of the original fragments of Aufzeichnungen as many as a dozen times and adding much new material, Roth proceeded to transform its first-person narrator into the figure of the schizophrenic, albert einstein, who lives in the illusion that he is the great scientist of the same name.

\footnotetext{
${ }^{122}$ W. V., 'Die Schizophrenie der Kunst', pp. 167-168.

${ }^{123}$ Roth in Gegenwartsliteratur - Mittel und Bedingungen ihrer Produktion: Eine Dokumentation, edited by Peter Bloch, (Bern, 1975), pp. 334-336 (p. 334).
} 
By the end of 1970, after four years of part-time work on einstein, Roth had almost completed the manuscript of the novel. A friend, Dr Königshofer, a teaching assistant at the 'Technische Hochschule' in Graz, insisted that he be allowed to read it. He borrowed the manuscript to read at home. Acting on his own initiative, Königshofer made two copies and sent one directly to Suhrkamp for evaluation. The second he gave to Roth, who, after he had heard nothing from Suhrkamp, sent it to Hanser Verlag. Shortly afterwards, Hanser sent Roth a rejection-slip. While waiting for a reply from Suhrkamp, Roth wrote the 'Kurzroman', How to be a detective. This, together with the third section of einstein, he submitted to manuskripte. Kolleritsch rejected them both. It is not clear whether he would not or could not publish either text for reasons of style or simply because the issue was already over-subscribed. He was, however, interested by what he read and invited Roth to visit him in Brunsee where he was spending his summer vacation. It was already mid-1971. Suhrkamp returned the manuscript of einstein. The editor concerned was Thomas Beckermann who was to become Roth's editor at Suhrkamp, and later, as the result of a dispute with Suhrkamp, at S. Fischer Verlag. Beckermann had experienced difficulty deciphering the text and, moreover, was not yet sure what to make of it. Roth sent Beckermann the manuscripts of his detective story and Künstel, another 'Kurzroman' which he had written after laying aside einstein in 1970. Roth then went on a business trip to Copenhagen and on that journey wrote a further 'micro-novel', Der Ausbruch des Ersten Weltkriegs. On his return to Graz, he travelled to Frankfurt to meet Beckermann. Beckermann expressed considerable interest in einstein and asked Roth to prepare a full typescript. Roth declined because he lacked both the time and money necessary to do so. He sent the manuscript back to Suhrkamp as it was: 'Ein paar Wochen später erhielt ich einen Brief, daß man die autobiographie des albert einstein im Frühjahr 1972 herausbringen wolle. Es war ein Sommertag und ich legte mich in einem Schwimmbad in den Schatten und schlief bis zum Abend. ${ }^{124}$

Before the year was out, Kolleritsch accepted Künstel for publication in manuskripte (33/1971). Although Künstel appeared in manuskripte a few months before einstein was released by Suhrkamp, Roth's early publishing history nonetheless reverses the pattern established by other authors of the Graz Group. In keeping with Kolleritsch's observation in his 'marginalie' to the 25th anniversary issue of the magazine - 'Viele Autoren sind von den manuskripten weg ihren Weg zu den Verlagen gegangen' ( $m$ 89-90/1985) Handke, Frischmuth, and Jonke, for example, had come to the attention of Suhrkamp through the appearance of their work in manuskripte. Roth, in contrast, as a result of Königshofers's intervention, had gone directly to Suhrkamp. It must be added, however, that by 1971 the growing reputation of

${ }^{124} \mathrm{G}$. R., 'Über seine "autobiographie des albert einstein"', Die Presse, 1/2 December 1979 (Beilage). 
Graz in the publishing trade as a 'Genie-Ecke' was sufficient to ensure that out of the hundreds of literary manuscripts received annually by Suhrkamp, Roth's would at least be read. The prior appearance of Künstel in manuskripte led a number of reviewers to assume that he had come to Suhrkamp as one of the 'manuskripte-autoren' when, in fact, the reverse was true.

Under the editorship of Beckermann, die autobiographie des albert einstein and the remaining works of Roth's 'subjective phase' were published by Suhrkamp in three relatively expensive ('broschierte') paperback editions between the Spring of 1972 and the Spring of 1973. The second volume entitled Der Ausbruch des Ersten Weltkriegs, contained, in addition to the title story, Künstel: ein Fragment and How to be a detective: Ein Kriminalroman. The third, with a gouache by Peter Pongratz on the front cover, contained Der Wille zur Krankheit.

\subsection{4 die autobiographie des albert einstein}

In einstein, Roth is not interested in presenting a literary version of a case of schizophrenia any more than Handke is in Die Angst des Tormanns beim Elfmeter. Rather he is concerned to probe the fictional nature of the consensus reality we employ as members of a rational technological society to define the boundaries of 'normal' or 'sane' experience. We act mostly in the firm belief that our judgements about reality have as their foundation the incontestable evidence of science. The literary gesture of defiance of the conventions of normality displayed by the protagonist of Aufzeichnungen, as Roth's interest in Hamsun indicates, had its roots in the nineteenth-century type of the bohemian 'flaneur'. This gesture is now brought up-to-date in einstein's aesthetic attack on the misplaced confidence of scientific man. Roth had rapidly come to understand that bohemian forms of literary protest were historically outmoded. He could learn a great deal more about the origins of his sense of disorientation and disenchantment with conventional interpretations of the world by turning away from earlier models of the alienated outsider figure. In einstein, he concentrates instead on what he had himself learned, as an initiate of the natural sciences and therefore as an 'insider', about the ways in which the experience of so-called everyday reality is constituted:

... wenn wir uns vorstellen, daß unsere Wahrnehmungsapparate nur Ausschnitte von einem riesigen Spektrum an Wellenlängen sehen, von Schallwellen hören usw., so stellt sich die Frage, was Realität überhaupt anderes ist als Fiktion. Realität ist das, was unsere Wahrnehmungsapparate uns ver- 
mitteln. Aber das ist bereits äußerst fragmentarisch und auch unterschiedlich (siehe bei Geisteskranken). ${ }^{125}$

The intensity and sensitivity of Roth's own perception of the world around him, his natural ability as an observer of fine and significant detail, has exercised a definite influence on the direction and style of his writing: 'Ich glaube, daß ich sehr empfindlich wahrnehme. Insofern beeinflussen meine Wahrnehmungen der Außenwelt auch meine schriftstellerischen Arbeiten'. ${ }^{126}$ In einstein, the doors of perception are thrust open. Roth sets out to explore the realms of experience which become manifest when the rigid categories of logic and scientific rationality are exploded. Consciousness, freed from the habitual restrictions which tend to reduce the world to repetitive banality, is laid open to the transforming effects of untrammeled acts of imagination. The theoretical constructs, the descriptive and analytic methods of science are brought to focus on the teeming life of the senses and the perceptual minutiae of the prereflective consciousness. From the resulting collision between rationality and the moment-to-moment flux of events occurring at disparate levels of existence, there emerges the wildly colourful, intriguingly intricate, often bizarre, sometimes scurrilous, and even perverse world of the schizophrenic, einstein. In the original Suhrkamp edition, the text of einstein runs to some 116 pages and is divided into five sections. This playfully impossible 'autobiography' ${ }^{27}$ well exemplifies the 'Sprachspiel' element in the literature of Graz. The narrative opens with a two-page description of the growth of einstein's embryo. It is written in the style of a biological outline, highlighting the unusual development of the brain, and is accompanied by a rough diagram. From the outset the reader is made aware of the author's easy familiarity with the terminology of medical science. Appended to this brief introduction is a reproduction of the well-known photograph which shows the historical Albert Einstein poking his tongue out at the camera and presumably the whole serious-minded world as well. Underneath the reproduction of this photograph is a short physical description of einstein after the manner of a 'wanted' poster, based on facts pertaining to the real Einstein who was, as he is here, classified as a 'technischer experte III. klasse' while employed at the patent office in

\footnotetext{
${ }^{125}$ Bloch, p. 334.

${ }^{126}$ Bloch, p. 334.

${ }^{127}$ Roth's ironic use of the autobiographical genre has some precedent in the literature of schizophrenia. In its gesture of fictional omnipotence, it resembles at times the type of fantasy autobiography sometimes produced by schizophrenics. See for example Adolf Wöfli, Von der Wiege bis zum Graab. Oder, durch Arbeiten und Schwitzen, Leiden, und Drangsal, bettend zum Fluch. Schriften 1908-1912.[sic] Band 1. Band 2. Bearbeitet von Dieter Schwarz und Elka Spoerri. Hg. von der Adolf-Wölfi Stiftung, Kunstmuseum Bern, (Frankfurt/M., 1985). Extracts appear in English translation in Another World: Wölfli, Aloise, Müller, (Glasgow, 1981).
} 
Zurich and also spoke 'korrekt französisch mit einem leicht fremdländischen akzent'. (In keeping with the typographical convention favoured by practitioners of 'experimentelle Literatur', lower case lettering is used throughout the text of einstein). Following the introduction, which the reader is free to interpret as the work of the schizophrenic, einstein, or as the addition of some later editor, are the three major divisions of the narrative: 'der voyeur', 'spaziergänge durchs cerebrum', and 'der observateur (eine skizze)'. The narrative is rounded off by a reproduction of an autopsy report on which the name of the patient and the name of the pathology institute have been roughly blacked out. ${ }^{128}$

The sections, 'der voyeur' and 'spaziergänge durchs cerebrum', take the form of a first-person interior monologue. Shortly after the beginning of the 'observateur' section, the monologue changes abruptly in mid-paragraph from einstein's first-person 'ich' to a third-person-schizophrenic 'er':

schon hatte sich die naturerscheinung verflüchtigt und ließ mich, den aufzeichnenden betrachter mit meinem selbstgespräch zurück. nichts außergewöhnliches war mehr festzustellen. so vergingen die tage. eines morgens nahm der betrachter einen stiefmütterchen ähnlichen geruch wahr. der himmel bog sich vom firmament herab. die straßen waren merkwürdig gebogen. er vermochte in der sprache der vögel zu denken. (MBM, p. 230. Emphasis added by SCR).

From this point on, einstein's 'Ich' is grammatically suppressed, present only by implication as the logically necessary precondition of the Observer's further experiences. The effect on the reader of this sudden change of narrative key is to become disturbingly aware of einstein's suppressed 'Ich' as a ghostly presence behind the pathological objectivity of the grammatically and otherwise 'ver-rückt', third-person persona of the 'Betrachter'. The parallel between this division of einstein's psyche and the situation of Roth, or indeed of any author, in relation to his fictional projections through the first-, second-, and third-person voices possible in the text, although inherent from earliest times in the craft of fiction, is nonetheless part of the fascination of this work. As Vogt has succinctly observed of the relationship between the self-projections of the artist and those of the psychologically disturbed: 'Einiges entdeckt man schon, wenn man schreibt ... wenn man sonst nichts erfährt, erfährt man etwas über sich selbst. Alle Personen, die man erfindet (tatsächlich sind sie ja weniger erfunden als erfahren), sind Personages, ... bald mehr im Sinne von Joan Miro, bald mehr im Sinne der jungen Schizophrenen der

${ }^{128}$ This document was very likely a souvenir of Roth's studies at the 'Pathologisches Institut der Universität Graz'. 
Madame Sechahaye' ${ }^{129}$ einstein is not a fully rounded character in terms of realist conventions, mainly because his identity is fragmented and has no substantial links to an external social world. For Roth, the figure of einstein is a narrative device - 'AE, eine Formel' - whose primary function is as a vehicle for his own explorations. This does not, however, detract from the intensity and substance of the 'world' einstein inhabits.

In this early, 'subjective phase', Roth scarcely conceived of the work as part of a personal literary programme, and yet as Jörg Drews later commented, einstein is an extraordinarily ambitious project, 'ein ehrgeiziger Wahnsinn,, 130 and it is not surprising that at times the text aims at goals which lay beyond the reach of a young author in one relatively short book.

Ein Fall von Schizophrenie soll dargestellt werden, der aber zugleich für etwas viel Umfassenderes, nämlich den Zusammenbruch eines ganzen Weltbildes stehen soll; Erzählmuster sollen parodiert sein, Sprachphilosophie, Kritik des wissenschaftlichen Denkens, generell des Rationalismus sind auch vorgetragen darin, und Aufrufe zur Anarchie aus dem Buch herauszulesen ist wohl ebenfalls nicht verfehlt. ... Also wird sein Wahn (einsteins) als kritische Instanz, als Medium möglicher Einsichten ernstgenommen. ${ }^{131}$

In einstein and the 'Kurzromane' which follow, Roth presents the reader with a literary text which consciously disavows the traditional pretence of the novel to universality. The implausibilty of einstein as mimetic art is immediately apparent in Roth's treatment of the autobiographical genre. The withdrawal of traditional literary gestures of plausibility tends, as Christine Brooke-Rose observes, to dramatise 'the theme of the world's non-interpretability'. ${ }^{132}$ einstein willingly acknowledges its eccentricity and the partiality of its vision of the world: 'ich kitzle ja nur meine eigenen kunststücke aus meinem introvertierten kopf!' (MBM, p. 202). einstein is an anti-novel. On an international scale it can be seen as an example of non-traditional or postmodern fiction. In its 'willingness to allow the compositional act a self-conscious prominence and to invest that act with love, a sense of game, invention for its own sake, joy', einstein is an instance of what Philip Stevick in his study of the 'New Fiction' of the 1970s characterises as 'fabulation' ${ }^{133}$ In German literature, this tendency

${ }^{129}$ 'Die Schizophrenie der Kunst', p. 170.

${ }^{130}$ Jörg Drews, “'Haid setzte die Brille wieder auf...': über Gerhard Roths Bücher”, in Laemmle and Drews, p. 29.

${ }^{131}$ Drews, ibid, p. 29.

132 'Where do we go from here?', Granta, 3 (1980), pp. 161-188 (p. 162).

${ }^{133}$ P. S., Alternative Pleasures: Post-Realist Fiction \& the Tradition, (Chicago, 1981), p.

25. Stevick echoes the earlier observations of Robert Scholes: 'Of all narrative 
is represented from the early 1960 s by the appearance of works in which the traditional novel is dissolved into what Heinrich Vormweg, borrowing a term from the aesthetics of music, describes as 'Literatur als Etüde': 'Die Etuide berichtet nicht von einem Geschehen, sondern nur von seinem Vorhandensein. Sie zeichnet eine Linie, eine Nahtstelle nach, alles andere läßt sie offen. Ein technisches Motiv ist insofern angedeutet, als sie die Linie genau und nachdrücklich begrenzt. Das, worum es geht, bleibt unbekannt' ${ }^{134}$ In Austria, 'Literatur als Etuide' appears initially in the work of the 'Wiener Gruppe'. The earliest and perhaps most extreme example of this tendency amongst the 'Grazer' is Handke's Die Hornissen which forces the reader either to enter actively into a demanding process of interpretation or abandon the narrative as unreadable in the conventional sense. Handke's second novel, Der Hausierer, makes similar demands. In Die Angst des Tormanns beim Elfmeter, some concession is made to realism but the narrative is still far removed from the illusionist tradition. Parallels can be found in the narrative construction of Kolleritsch's novels, Die Pfirsichtöter and Die grüne Seite. Eisendle and Hoffer also set up an obstacle-course which keeps the reader from any glib assumptions about the supposed content of their narratives. Eisendle employs a deliberately mannered form of the Socratic dialogue while Hoffer makes extensive use of carefully embedded quotes from literature and philosophy. The term 'Etüde' is also appropriate to Jonke's work, much of which pivots on the argument that what we perceive as reality is an illusion analogous to the illusion created by music and the visual arts. The structure of Geometrischer Heimatroman and later novels like Schule der Geläufigkeit and Der ferne Klang resembles that of formal musical compositions. In all these novels the reader is struck by the recurrence of the 'Sprachspiel' element, especially by the now sceptical, now despairing, now hopeful literary play with the relativism and sense of unreality expressed in Wittgenstein's proposition: 'Alles, was wir sehen, könnte auch anders sein. Alles, was wir überhaupt beschreiben können, könnte auch anders sein' (Tractatus, 5.634). Strong connections also exist in this respect to the work of other Austrian authors outside the Graz circle, including Thomas Bernhard, Ingeborg Bachmann, and Peter Rosei. ${ }^{135}$

Roth's einstein rages against an over-organised world: 'alles auslöschen, begriffssysteme abstoßen, assoziationen vernichten, zwänge zerstören, neu wahrnehmen, exzessiv aufsaugen, traditionelle inhalte aufgelöst, aufgelöst, aufgelöst, neue relationen schaffen, ich selbst als zusammenfügender, ord-

forms, fabulation puts the highest premium on art and joy': R. S., The Fabulators, (New York, 1967), p. 10.

${ }^{134}$ H. V., 'Literatur als Etüde', Jahresring, '64/'65, pp. 248-261 (p. 51).

${ }^{135}$ For a broader survey of recent Austrian literature in this connection, see the essay 'Der Tod des Nachsommers. Über das "Österreichische" in der österreichischen Literatur', in Ulrich Greiner, Der Tod des Nachsommers, pp. 11-57. 
nungszahlen vergebender! wie ich zusammenhänge hasse!!' ( $M B M$, p. 195). What is occurring in einstein and is repeated with variations in the other 'Kurzromane', is a willed defamiliarisation, a further manifestation of the perennial revolution of art which the Russian Formalist artist and critic, Victor Shklovsky, summed up in 1914 as: 'The death of things ... the resurrection of things - the return to man of sensation of the world'.$^{136}$

The rediscovery of the sensation of the world through language is at the heart of 'Grazer Literatur'. The absence of the element of surprise in the 'Beschreibungsliteratur' with which Handke took issue in Princeton in 1966 is part of what motivated the Graz authors to experiment with new literary modes. Through an act of revolt against habits and conventions which have rendered the mind dull and insensitive to the many vital experiences, which in einstein Roth locates in the unrealised aesthetic potential of science, the author sets about poeticising what lies concealed behind the veil of our everydayness. In the process, the seemingly familiar may be rendered strange and even threatening, but the result is that the world as the unknown totality of experience is left essentially open to interpretations other than the closed views the author is attacking - here the reductionist, utilitarian values of consumerism and technocracy: 'ich ziehe das wirre durcheinander aus erfundenem und konvulsivisch beobachtetem den systematischen klosettspülungen menschlicher kommunikation vor, ich scheiße auf eure sprache, die gedanken determiniert!!!' ( $M B M$, p. 204). For an author to be in revolt against what Leslie Fiedler terms the 'platitude of meaning', is not necessarily to be against the possiblity of meaning altogether. It is an important strategic move in the efforts of the Graz Group to create an open-minded attitude to aesthetic experience. What makes einstein characteristic of the approach to meaning found in numerous examples of 'Grazer Literatur' is Roth's self-conscious withdrawal from habitual acts of interpretation. The two decades from 1960, in which 'Grazer Literatur' was in the process of formation, represent a period of minimal interpretation in relation to the dominant ideologies of the period. This is one sense in which the 'Grazer' have been described by their critics as 'Verweigerer', but there is a certain historical necessity in their recognition of the value of a radical reduction in the ascribing of 'meanings' to experience to avoid the suffocation of the psyche which occurs when the life of a society becomes dominated by a plethora of reductionist over-interpretations. It is the one-way system of meaning which terminates in the self-satisfied, decidedly 'spießbürgerliche' existence of Austrian urban-industrial man to which 'Grazer Literatur' is uncompromisingly opposed.

The discovery of the relative, conditioned nature of what was once taken to be the indisputable identity of the individual had already provided a rich field

${ }^{136}$ From the essay 'The Resurrection of the Word', quoted in Russian Formalism, edited by S. Bann and J. Bowlt, (Edinburgh, 1973), pp. 41-47 (p. 41). 
of ideas for earlier, 'classical' Modernist authors. Moreover, works such as Musil's Der Mann ohne Eigenschaften are permeated with regret for the loss of a previously possible order. For Roth and other 'Grazer' - Handke's later work diverges in this respect - writing some two and a half decades after Auschwitz and Hiroshima, the longing for this previously possible order proved irreconcilable with their very different experience of life in the Second Republic. The relativism of human knowledge and therefore of individual identity was already an established fact. Like many of his contemporaries, Roth could look back on a childhood which contained memories of the last, destructive days of World War Two and the immediate chaotic aftermath of life under the Allied occupation. He saw no reason why the novel form should continue to lend a fictional coherence to events which belied experience. In einstein, the traditional pretence of the coherent narrator as the relatively stable controlling instance and syntactically fixed locus ('ich' or 'er') of the narrative is undermined by einstein's susceptibility to adopting depersonalised perspectives on himself. He has experiences and sensations which confuse and confound his sense of identity, leaving his ego amorphous, a random assemblage of fragments: 'du gehst weiter und siehst von jeglichem ding nur'n bruchteil: nicht mehr er selbst, sondern sich als eine möglichkeit empfindend, ausgelöscht, ein physiologisches luftgebilde, ein etikettierter wahrnehmungsmechanismus' ( $M B M$, p. 235). einstein enjoys the licence of the insane to wander blithely backwards and forwards across the conventional lines of demarcation between the rational and the irrational, obliterating the compulsion to distinguish between fact and fancy. In accordance with the linguistic definition of schizophrenia, he is entitled to wander without a trace of bad conscience between first-, second-, and third-person versions of himself: Each of these grammatical masks can seem as personal or as impersonal as the others in relation to his fluid sense of identity. At no point is einstein obliged, as is the narrator in a conventionally realistic novel, to come 'back to himself' and render a narrative 'account' of his experience. Roth is thus freed from the necessity of contriving a linear plot and is able to portray all manner of events without having to draw them into a closed interpretive scheme. einstein is essentially plotless. The narrative energy of the text is centrifugal. Roth moves away from what he felt to be the temptation to subordinate events to preconceived patterns which in many, conventionally realistic novels compel the reader to link events to an a priori source of signification from which, as in the detective genre or in a work of socialist realism, they alone derive meaning.

The relativism Roth expresses here owes more to the real Einstein and the vein of epistemological doubt which runs through the philosophy of science in this century, than it does directly to Wittgenstein. Roth is less concerned with the doubts about language and the possibility of genuine human communication which amongst the 'Wiener Gruppe' preoccupied Bayer and Wie- 
ner in particular. What engages his attention are doubts about our perception of reality - the product of the second branch of the 'Sprachkritik' which springs from the reflections of physicists like Mach, Boltzmann, and Brentano on the nature of science. The two strands are of course interwoven: it is the emphasis which is different. While working on einstein, Roth steeped himself in 'wissenschaftliches Material über Mathematik und Physik, unter anderem, um den Stil, in dem dieses Material abgefaßt ist, zu analysieren' (Bloch, p. 335). Late in the nineteenth century, it was the findings of positivist science which had begun to dissolve the identity of the classical or romantic individual: art as Naturalism and Impressionism bowed to accommodate the new world-view. Now in the later 1960s, it was the turn of science to confess the relativity of its truth to art: scientific method was not a guarantee of unfailing objectivity, but was being demonstrated by disciplines as varied as philosophy, linguistics, and the sociology of knowledge to be dependent on other quite subjective human values. ${ }^{137}$ Roth's first-hand experience of the medical establishment and largescale data processing left him in no doubt that scientific knowledge is intimately related to power. To question the ultimately rational nature of science, to equate its findings with fiction, subjecting them to aesthetic processes which reveal the colourful organic chaos behind the mask of the sober, discursive statements of scientists as Roth does in einstein, is, by implication, to cast doubts on the legitimacy of the many social institutions which derive their authority from public acceptance of the notion that the scientific enterprise is always a rational one. Roth summed up his attitude to the relationship between science and reality in 1975 with a reference to einstein:

Die Fiktion ist für mich eine Form der Realität. Schreiben heißt fiktive Wahrheit erzeugen. Insofern ist die Fiktion nur eine andere Form der Realität und die Realität eine andere Form der Fiktion. In diesem Zusammen-

${ }^{137}$ Since the early 1960 s, a number of studies have served to progressively undermine the notion of the unity of science as a coherent set of rational activities which foster the steady accretion of knowledge. Kuhn's study, The Structure of Scientific Revolutions (1962), has already been referred to in another context. Kuhn demonstrated conclusively that science is a human activity and, as such, is as likely to manifest irrational behaviour as any other human activity. Herbert Marcuse, Max Horkheimer, Theodor W. Adorno, and Jürgen Habermas of the 'Frankfurter Schule' have contributed a great deal to the study of positivist ideology in advanced industrial society. Marcuse's One-Dimensional Man, (London, 1964), Habermas's Erkenntnis und Interesse, (Frankfurt a.M., 1968), and Horkheimer's Kritische Theorie, (Frankfurt a.M., 1968), all involve a critique of 'scientism'. Stephen Toulmin's work in the 1970 s on the philosophy of science in this century is also of note. Roth was familiar with some of Horkheimer's work and refers to his ideas in Der große Horizont, pp. 31-32. Marcuse's critical ideas were widely disseminated through counter-cultural publications during the late 1960 s and Roth would certainly have been aware of them. 
hang möchte ich wieder die autobiographie des albert einstein erwähnen. Was ist Realität? "die wirklichkeit der naturwissenschaften ist nicht wirklich! sie ist rauschhafter und entfremdeter als die eines wahnsinnigen."138

The passage from einstein referred to here continues: 'ihr gedankengebäude ist ein willkürliches, anthropomorphes, axiomatisches! menschliche intelligenz schließt aufgrund selbstgebastelter, selbst lizensierter, selbst als objektiv bestätigter apparaturen!' ( $M B M$, p. 228). The critical stance which Roth adopts towards science in einstein is not aimed at entirely demolishing its validity, but satirically plays up the limitations of the scientific viewpoint: '(anmerkung des autors: ich halte den wissenschaftlichen versuch, die eigenartigkeit der menschlichen befindlichkeit in der welt auf das kategoriensystem der biologie oder auch der chemie oder physik zu reduzieren, für an sich legitim, jedoch für nur begrenzt fruchtbar und für prinzipiell unzulänglich.)' (MBM, p. 214). In his 'optimierung 1' (p. 228), einstein asserts that nature herself is contradictory and asks why this should be so upsetting when we, after all, are part of nature. The photograph of the historical Einstein at the beginning of the text, provides an emblematic key to Roth's treatment of the paradoxical nature of scientific reasoning. Einstein's tongue-poking gesture encapsulates his own merry defiance of the narrow-minded and arrogant seriousness he so strongly opposed in his writings, as well as the satirical attitude of Roth's narrative to those scientists and others who, in the positivist tradition of Comte, Mill and their intellectual descendants, still persist in the assumption that the rationality of science (as opposed to its rationale) is anchored in a set of atemporal logical criteria. The popular view of the historical Einstein is that of the playfully eccentric, absent-minded professor whose 'madness' is benevolent. In the figure of the schizophrenic, einstein, whose insanity rests on the delusion that he is the great scientist himself, the repressed irrationality of the supposedly rational scientific world-view is allowed to burst forth: 'in meinem kopf klappern die relais ... traumtänzerische phase! ich rase durch die kräuselungen des gehirns, ich blicke durch die gläserne kugel der augen ... köstliche wortbläschen platzen in meinem gehirn, bekleckern meine wahrnehmung, triefen von mobiliar. in wortplunder kondensierter wahrnehmungsnebel!' $(M B M$, p. 163).

einstein proceeds from a gesture of extreme subjectivism. In technological societies, social and economic pressures to conform to the dictates of scientism coerce the individual into surrendering vital areas of the creative imagination to the imagined total objectivity of science. Roth sets out to reappropriate these cognitive territories aesthetically. By revealing the irrational, aesthetic potential of the emotionally neutral, object-language of science, Roth moves to rescue his subjectivity from the sterility which results when analysis and classification

${ }^{138}$ Bloch, p. 334. 
serve no longer as means, but as ends in themselves. einstein asserts that the individual subject is the only possible experiencer of the world(s) created through the propositions of science. In this satirical reconnection of knowledge as scientific information with knowledge as personal aesthetic experience, Roth discovers that his sense of displacement is linked to the fragmentariness and relative unreality of the numerous models of man and nature created by science. In contradiction to what many apologists for the 'Institution of Science' would have us believe, the images generated by the many branches of science do not necessarily tend towards a unified and rational whole, but amount to a dizzying maze of competing, contrary, and even contradictory perspectives on our existence made possible by the sheer productive power of language: 'die wirklichkeit war unauffindbar. ich fand keine wirklichkeit. der baum ist schließlich und endlich ein vokabel. die sprache absorbiert meine wirklichkeit' ( $M B M$, p. 221).

einstein leads the reader into unexplored territories of the imagination, 'zerebrale Paradiese' which Roth portrays with the skill and precision appropriate to his scientific training, but also with the unpredictable and obsessive enthusiasm of his schizophrenic narrator:

er empfand mit einemmale das flimmern seiner millionen sehzäpfchen als kitzel in seinem gehirn. er tastete die farbigen gegenstände an wie wunderwerke. das licht durchraste mit einer wellenlänge von 670 millimü seine lippen. erschrocken zog er seine finger zurück. unter seinen füßen das gelb, auf den töpfen das violett, auf seinem stuhl das blau, auf dem vogel das grün, auf dem tisch das schwarz, auf seinen knöpfen das messing, auf seinen händen das weiß, in seinen augen das braun, auf den blättern das lila ... er zwang sich, die chemischen umsetzungen, die das licht in seinen rezeptoren erzeugte, als temperaturschwankungen zu empfinden. der observateur war ein meßinstrument! ( $M B M$, p. 245).

Of all the rhetorical devices which Roth avails himself of in einstein in his attempts to persuade the reader to see the world anew, perhaps the most successful in its ability to deconstruct discursive, reductively objective discourse 'die sprache, die gedanken determiniert' - is his use of the metaphorical mode of expression in the form of a benevolent surrealism. Working from Roman Jakobson's notion of the binary opposition between metaphor and metonomy as a fundamental mechanism operating within all language behaviour, the British critic, David Lodge, has distinguished two modes of language or discourse - the metaphoric mode and the metonymic mode. All literary forms tend towards the metaphoric, while referential forms of writing and speaking, such as are found in scientific prose, are predominantly metonymic. In practice, the metaphoric and metonymic modes operate simultaneously as inter- 
dependent poles in the force field of language, but, as Lodge demonstrates, particular forms of expression tend more towards one pole than the other. ${ }^{139}$ The metaphorical language which provides the surrealistic element in einstein is largely benevolent and playful. It is sharply juxtaposed to the metonymic, scientific statements which Roth deconstructs. The connections einstein makes between normally disparate levels of existence are presented in a noninterpretive manner as open-ended possibilities. There is an undercurrent of humour which runs at times in a black vein, but nonetheless rescues einstein's insights from the scathing misanthropism which contemplation of the organic processes of living and dying produced, for example, in the work of Gottfried Benn. Although einstein experiences moments of repulsion and anxiety at the thought of being engulfed by the teeming life around him, the similes and metaphors he uses reveal overall a sense of wonder and fascination with the macrocosms amd microcosms revealed by his extraordinary sensory apparatus:

auf den schwarzen regenschirmen kleben gelbe, von den bäumen abgefallene blätter. ich stelle mir die muster der blätter vor, das filigrane geäder, die seltsam geformten ränder. ich sammle diese momente von klarheit wie insekten oder wie ich buchstaben sammle, die ich in gedanken förmlich auf mein gehirn spieße und in imaginären glaskästen einordne ( $M B M$, p. 164).

... worte wie regentropfen kitzelten meine hirnhaut (MBM, p. 168).

jedes wörtchen wird zu einem opiat, das ein flimmern von bildern, eine sturzflut von neuen worten auslöst. das tapetenmuster aus violetten gasflämmchen wirkte wie ein narkotikum ( $M B M$, p. 204).

He reserves his scorn for the limitations of his own being - 'mein amorphes scheiß-ich!!' (p. 208) - and the more repellent aspects of his fellow citizens 'sehe ich in einiger entfernung eine schwangere, fette frau außer sich vor zorn über ein kind herfallen und es mit heftigen schlägen züchtigen. jaja, madam, schlagen sie nur zu, ich kann ihnen nur beipflichten' (p. 201).

einstein's sense of isolation is intensified by his acute perception: 'ich litt an meinen wahrnehmungen wie an einer krankheit' $(M B M$, p. 172). There are moments in the text when Roth's authorial presence manifests itself almost too directly. Roth's own feeling of isolation is barely concealed in comments like the following taken from the 'observateur' section: 'sein wissen vereinsamte ihn nur noch mehr. was ihm blieb waren seine präzisen, klaren aufzeichnungen,

${ }^{139}$ David Lodge, The Modes of Modern Writing: Metaphor, Metonomy, and the Typology of Modern Literature, (London, 1977). See Part Two, 'Metaphor and Metonomy', pp. 73-124. 
die die nachwelt erqwicken (sic) würden' ( $M B M$, p. 238). Isolation induced by sensitivity, acute perception, and intelligence which does not conform to normally accepted patterns, is a recurrent theme in Roth's work. The above sentiment is echoed in the later 'Kurzroman', Der Wille zur Krankheit: 'Durch das Fernrohr seiner Isoliertheit, beobachtete er ...' (MBM, p. 340. Emphasis SCR). Roth's interest in the Austrian schizophrenic poet, Alexander (Ernst Herbeck), is motivated in part by a sympathetic appreciation of Herbeck's situation. He notes that Herbeck speaks to us: 'Nicht aus einer Welt der Verrücktheit, sondern der Isolation, nicht aus einer Welt der 'Normalität' (womit stillschweigend auch alle Lügen gemeint sind, die für die Aufrechterhaltung der bestehenden Ordnung notwendig sind), sondern aus einer der geschärften, aber verletzten Sinne, ${ }^{140}$ Such isolation is a thematic preoccupation Roth shares with other Graz authors. While reflection on the isolation of the individual subject is nothing new when considered in terms of international literary history over the past one hundred years, in Austria and in Graz in particular, it becomes a problem of language and perception: 'ich verkrieche mich unter meiner schädeldecke ... ich lebe in meine gedanken eingesponnen, wie ein kokon. ... nur noch hirnreisen. das gehirn, das auge, die wahrnehmung. ... andere menschen sind schatten, skurrile erscheinungen, flüchtiger hirnreiz' ( $M B M$, p. 199) - 'ich, der voyeur ... ich selbst bleibe jedoch unberührt' ( $M B M$, p. 203). In the figure of Joseph Bloch in Die Angst des Tormanns beim Elfmeter, Handke presents a study of the isolation of an individual who experiences a disturbing breakdown in the relationship between language and his consciousness of the external world. The protagonist of Kolleritsch's second novel, Die grüne Seite, struggles to liberate himself from a world of ossified word-images which threaten to trap him in the negative mentality of his father's generation. Eisendle grapples with the all-encompassing nature of language and the problem of solipsism in Jenseits der Vernunft oder Gespräche über den menschlichen Verstand: 'Alles ist erfunden, gefunden in meinem Gedächtnis, ein Teil von mir ... Der andere Pol, es ist kein Pol, der andere bin ich selbst, verschwommen, eine unsichere Beschreibung ... (p. 7)'. On the one hand, Eisendle expresses the melancholy of this insight, while on the other he experiences new delight in the aesthetic play with language - 'der Spaß am Sinnlosen' (p. 9): 'Ich spiele mit dem Geist der Erinnerung, ich experimentiere mit dem Bewußtsein, dem Gedächtnis, mit dem unfähigen Mittel Sprache' (p. 9. Emphasis SCR). In his two 'Bieresch' novels, Hoffer creates a complex analogue to the epistemological doubts which plague contemporary 'Sprachphilosophie' and undermine the identity of Hoffer's firstperson narrator. The Bieresch inhabit an apparently closed and meaningless (although not unpleasant) world and yet language tantalises them at every turn

${ }^{140} \mathrm{G}$. R., 'Eismeer des Schweigens: Ernst Herbeck: Alexander - Ausgewählte Texte 1961-1981', Die Zeit, 14 January 1983, p. 36. Emphasis SCR. 
with the possibility of meanings to which they have lost the key: 'Sinnruinen glotzen uns aus der Sprache an ... Die Überlieferung funktioniert nicht. - Die Schriften hat man uns überlassen, nicht aber die Anleitung, wie sie zu lesen sind. Lösungen haben wir, aber der Lösungsweg fehlt' ${ }^{141}$

In Die Verbesserung von Mitteleuropa, the most radical anti-novel to emerge from Austria since 1945, Oswald Wiener concludes that the almost universal assumption that a reality exists outside language has revealed itself as an illusion. He regards the act of comparing linguistic representations with reality as a ludicrous misunderstanding of the nature of language: 'einen satz sagen, und ihn dann mit der wirklichkeit vergleichen, ihn gegen die wirklichkeit verteidigen ... den satz zurechtfeilen bis er paßt, der schlüssel des einbrechers, der die wahrheit stehlen will, ein tropf, die wahrheit eines andern, sesam'. ${ }^{142}$ Taken literally, Wiener's work points towards silence and the certain 'death' of 'literature'. Hoffer's narratives offer perhaps the most philosophically consistent exploration of the territory opened up in Die Verbesserung von Mitteleuropa. Roth's position is somewhat more traditional. He takes a more literary than philosophical view of Wiener's ideas on language. Wiener insists that all human reality, whether at the level of society and politics, or personal perception, is absolutely determined by language. He argues for a solipsism so complete that the only path left to effect change is through an attack on language: 'die organisation der wirklichkeit durch die sprache ist unerträglich', ${ }^{143}$ 'ein aufstand gegen die sprache ist ein aufstand gegen die gesellschaft'. ${ }^{144}$

Wiener sees no further use for the practice of literature: 'eine sprache deren gebilde zugeschnitten sind zur klösterei' ${ }^{145}$ and he has since produced no writing which falls easily into the category of literature. Die Verbesserung von Mitteleuropa is an encyclopaedic assemblage taken from an enormous range of different modes of discourse. They combine to form a text which is in no sense readable as a narrative in the epic tradition. The revolt against conventional literary and philosophical manifestations of this organisation is not only stated by Wiener, but enacted as he undermines and contradicts discursive statements by setting them within ironic contexts. Roth, in contrast, does not take issue with language itself as a determiner of reality, but concentrates his attack on reductive systems of classification which function within language and society to divide interested forms of rationality from the operations of the aesthetic imagination in the name of a spurious concept of scientific objectivity and the public good. Roth's form of subversion operates within language by knocking

\footnotetext{
${ }^{141}$ Halbwegs: Bei den Bieresch 1, (Frankfurt a. M., 1979), p. 148.

${ }^{142}$ O. W., Die Verbesserung von Mitteleuropa, (Hamburg, 1969), p. XIII.

${ }^{143}$ Die Verbesserung von Mitteleuropa, p. LII.

${ }^{144}$ ibid, p. CXLIV.

${ }^{145}$ ibid, p. XXXVIII.
} 
out the keystone 'objectivity' from the gateway of rational discourse. By removing the artificial barrier between language and experience demanded by the act of objectivising, Roth restores to language some of its lost magic. Consensus reality can be subverted by taking so-called objective descriptions literally, turning them back into the stuff of experience:

... wie die erde sich dreht,
was auf der erde während der
nächsten 10 schritte geschieht,
was in den weltmeeren geschieht,
die bewegung der erde um die
sonne, der einfluß des mondes,
aus welchen chemischen elementen
die luft besteht, was licht ist,
wie sich die galaxie dreht, wie
das weltall auseinanderstiebt
DIE GLEICHZEITIGKEIT ALL DIESER
PROZESSE, BEDINGUNGEN UND FAKTEN

\section{DAS RATIONALE LEBEN ALS FORM DER MYSTIK, ALS ETWAS TRAUMHAFTES (MBM, p. 211).}

Roth may share with Wiener a determined opposition to the 'organisation of reality' but nowhere in einstein does he ultimately despair of the power of language in a literary form to embody and communicate to others an altered experience of the world. His commitment to language remains literary and primarily logocentric. He retains a romantic and at times poetic longing to discover forms of language which will reverse the tendency of habitual discourse to induce a state of inertia. He seeks to liberate the imaginative, potentially transformative energy of the self and society from the daily rehearsal of ideas which no longer animate or activate the creative element in man: 'o münder, der mensch ist auf der suche nach einer neuen sprache, an der kein grammatiker irgendeiner nationalsprache etwas tadeln darf' ( $M B M$, p. 213).

A belief in the transforming power of language is also an essential element in Handke's work. Handke self-consciously establishes links to classical and romantic traditions in an effort to re-establish the vital link between language and experience which he hopes will rescue the human spirit from the degradation of excessive materialism: "Nach innen gehen" (Empedokles), hieße ja: ganz ins Innere der Sprache gehen; und im Innersten der Sprache wären Welt 
und Ich eins in der Sprache ("und freuten sich der ringsum herrschenden Einsamkeit": des sphairos)'. ${ }^{146}$

The first indications of a comparable interest in 'Sprachmagie' in Roth's work appear in einstein in the form of number and alphabet magic of a kind not uncommon amongst schizophrenics. einstein is obsessed with letters, numbers, and statistics: 'dann kam der herbst, es regnete allerlei buchstaben, hauptsächlich I und $\mathrm{U}$, ab und zu nur ein $\mathrm{Y}$ oder gar ein $\mathrm{W}^{\prime}$ ( $M B M$, p. 233). einstein recites lists of facts in the hope that their repetition will assuage his sense of anxiety. Like Handke's Joseph Bloch, whom he precedes, einstein experiences words, forms, and objects not as representations of something else, but as 'Dinge an sich'. The removal of the usual barriers between self and world, produces both 'zerebrale Paradiese' and moments of anxiety when einstein's identity dissolves and he loses himself completely in the flux of experience: '... urstoff und URzuStand D naaA? lungengeräusche gliedmaßen deliria undsoweiter. chromatische reize usf. ufff! wasserboiler siemens spiegelkliRR, stuhl knaCKs, strick zaCK, glühbirne blaFF, aaaaaaaAAAAAH!' ( $M B M$, p. 240).

Shortly after this expression of perceptual overload, einstein quotes the preSocratic philosopher, Heraclitus: 'aber heraklit sprach vormals: wie ein hingeschütteter misthaufen ist die schönste, vollkommenste welt' ( $M B M, \mathrm{p}$. 240). One possible meaning of this statement in the context of Roth's attack on society's misplaced confidence in the rationality of 'scientism', is that all lifeprocesses, including human cognitive functions, are caught up in a ceaseless ferment, in the never-ending cycle of regeneration and decay where the only constant thing is change. For Roth's narrator, as for Heraclitus, the endless flux of organic life is not a matter for despair only: it is also an occasion for wonder and contemplation of the mysterious, on-going nature of existence:

ich stehe hier vor meinem fensterbrett und lasse, wie ein stück draht den elektrischen strom, die abbildungen durch mich fließen (MBM, p. 165).

er apperzipierte mit genüßlichen äuglein. wurden nicht die blätter auf den bäumen von einem lufthauch auf das winzigste bewegt? sein cerebrospinales nervensystem reagierte ordnungsgemäß, seine gehirnteile erfüllten pflichtgetreu die ihnen zugewiesenen funktionen. selbst das licht fiel in form von zahllosen teilchen hell und durchsichtig zwischen den zitternden blatträndern vor die füße des beobachters. alsbald schritt er inmitten wiegenden gelben kornes durch die landschaft $(M B M$, p. 235).

${ }^{146}$ Die Geschichte des Bleistifts, (Salzburg, 1982), p. 182. This aspect of Handke's works is already extensively documented. See, for example, Rita Felski, 'Peter Handke's Langsame Heimkehr', AUMLA, 62 (1984), 208-225. 


\subsubsection{Künstel}

Roth's second experimental work, Künstel, was published by Kolleritsch in manuskripte some three months before einstein appeared in book form in the Spring of 1972. From the point of view of theme and narrative structure, this comparatively short text forms the bridge between einstein and the longer 'Kurzroman', Der Wille zur Krankheit. Roth conceives of certain of his works as complementary pairs in which he consciously experiments with the effects of a shift in narrative perspective. Treating Künstel and Wille as a unit, he regards them as forming a complement to einstein. Later he came to view Der große Horizont and Ein neuer Morgen similarly. The name 'Künstel' was taken by Roth from a text by Jonke, Künstel oder Horror der Idylle (1969). The major link between the two is the emphasis on the transformation of everyday experiences from the familiar to the unknown. Drews has noted with approval that in terms of narrative technique, Künstel represents a continuation of the method Roth developed in the third section of einstein, 'der observateur'. In the preceding sections of einstein, Roth had sometimes permitted einstein to comment directly on aspects of society, language, and the perception of reality. Although it is possible, as Drews has pointed out, to read many of einstein's 'insights' 'als kritische Instanz, als Erkenntnismöglichkeit, als Medium möglicher Einsichten', ${ }^{147}$ in the first two sections they occasionally represent an authorial voice which is intrusive and 'literary' in the negative sense of the word: An incongruous element is introduced in such statements as 'eine immer stärkere idiosynkrasie gegen alles hat sich in mir gebildet' $(M B M$, p. 204), or, 'dem ganzen literatenpack einen tritt in den arsch!' (MBM, p. 229). The first is a superfluous description of a state of affairs which has already taken the direct shape of einstein's actual experiences. The second represents a brief lapse into an immature literary posturing. Such instances are, however, remarkably few in what is, after all, the first work of a young author. In Künstel and Der Wille zur Krankheit, Roth eliminates this form of intervention in the text. By allowing himself to shift between first- and third-person perspectives in einstein, Roth portrayed einstein's dislocated universe from a narrative standpoint which was essentially external to einstein's psychological condition. In the third section, he succeeded in creating a fictional impression of einstein's schizophrenia from within through einstein's schizophrenic use of the third-person 'er'. In the preceding sections the boundaries between sanity and madness had been preserved to some extent. In Künstel, Roth experiments with the narrative effects which arise when events are consistently observed 'als ob Wirklichkeit und Wahnsinn eine einzige Ebene sind' (Interview 1):

147 “'Haid setzt die Brille wieder auf...": Über Gerhard Roths Bücher', in Laemmle and

Drews, revised edition, pp. 29-51, (p. 31). 
Im Kurzroman Künstel wollte ich den umgekehrten Weg gehen, nämlich $\mathrm{da} ß$ gespeicherte innere Bilder die Wahrnehmung der Außenwelt verändern, wodurch eine surreale Metaphorik entsteht. In diesem Fall konnte ich auf Literatur von Geisteskranken zurückgreifen. $\mathrm{Da}$ ich darauf zurückgreifen konnte, ist ein Resultat dessen, daß ich eben in einer Zeit schreibe, die bereits im Besitz dieser Information ist. ${ }^{148}$

In the 48 'Chapters' of Künstel, each of which is no more than a paragraph introduced by a laconic heading, the pathological elements present in einstein are isolated and intensified. The surrealistic humour of some of Künstel's perceptions distract the reader temporarily, but do not lessen the mounting sense of dread which runs through this series of dissociated images. The extremity of Künstel's situation and the general theme of the narrative is indicated in Roth's brief foreword to this perceptual adventure: 'Die Welt quoll durch seine Pupillen und prallte gegen das Gehirn. Wie durch eine zum Platzen gefüllte Ader pulsierte Außenwelt durch seinen Corpus' ( $M B M$, p. 252). When the narrative opens, the collapse of Künstel's identity is already well under way. After the manner of the true paranoid schizophrenic, Künstel is helplessly delivered up to the flux of ideas and sensations. Like his literary brother, Kalb, the central figure in Der Wille zur Krankheit, he 'hallucinates reality' in such an intense fashion that it threatens to engulf him. One of the most dramatic instances of the dissociation which besets Kalb occurs fittingly almost exactly at the centre of the text when he sees the earth open up to present him with the spectacle of her brightly shining magnetic currents. An attempt to show this 'Erdspalt' to his friend, Lotschak, fails and their friendship is impaired as a result. The fissure in the earth is an outward manifestation of the massive rift in Kalb's consciousness.

Künstel is an experiment with the technique of bringing to experiences approaching the extra-linguistic condition of 'direct perception', the minimum degree of literary form necessary to make them communicable to others. Even more than einstein, which still conducts an open dialogue between the condition of normality and the potential insights of a cultivated madness, Künstel attempts to escape altogether the subordination of experience to given modes of interpretation. Earlier, einstein had remarked: 'ich nehme bilder zu mir, wie drogen' ... 'ich spaziere durch meine gehirnkammern' $(M B M$, p. 177 and p. 181). In an interview with Jürg Laederach, Roth explains what he means by this:

Wenn man bewußt wahrnimmt, ohne sich dem Raster einer bestimmten Denkweise zu unterwerfen, wenn also das Sehen kein Erwartungssehen ist

${ }^{148}$ Bloch, p. 334-335. 
in dem Sinne, daß man nur darauf wartet, das Wahrgenommene in Klassifizierungskategorien einzuordnen, dann können Bilder wie Drogen wirken. ... Schauen Sie doch die Dinge an und versuchen Sie sie aus ihren Zusammenhängen zu lösen. ... Wer kann Ihnen das verbieten? ${ }^{149}$

Instead of merely talking, as he tended to do in einstein, about the existence of social and cultural repressions which work to diminish the quality and intensity of these perceptions, Roth now concentrates on presenting perceptions as directly as possible: 'Mit einem Schlag fielen die Äpfel von den Apfelbäumen. Lotschak lachte. Die Luft war zum Erbrechen mit Veilchenduft angereichert. Jedes Wort ließ einen Honiggeschmack im Munde zurück. Künstel betastete seine Schläfen. Ein scharfer Schmerz pflanzte sich in das Innere seines Kopfes fort. Konnte Lotschak durch Mauern gehen?' (MBM, p. 259).

Using the 'er'-form to narrate events from an imaginary focus entirely within the mind of Künstel, Roth simulates the disturbing effects of a consciousness registering its own workings like a fully automatic cybernetic device - 'eine chemische maschine'. Künstel's brain functions as an intelligent terminal in that it can put to itself the question: 'Welche Bedeutung hat das alles für mich? ... Diese Bilder hier und diese Sätze?' (MBM, p. 267), but the dissociation caused by the falling away of the usual logical connections between events is so complete that the quest for meaning loses its referential value and is swallowed by a sea of phenomena. The overwhelming immediacy of Künstel's thoughts, sensations, and perceptions renders him incapable of any systematic interpretation.

The presentation of a series of momentary impressions in the text functions in a manner similar to the montage units employed in early surrealist films. Like that of einstein, the narrative is plotless, yet the overall effect of the juxtaposed images is such that the reader's exposure to them in a linear sequence induces a distinct sense of narrative flow, a curious inner coherence, resembling the not unfamiliar and often fascinating 'logic' of a vivid, but inexplicable dream. The moments of cerebral irritation around which surrealistic experiences form in Künstel's imagination are recognisable fragments of everyday life in Graz: the appearance of a Jehovah's Witness at his frontdoor, a dangling fox's head on a young woman's fur-coat, the odour of camphor emanating from overcoats at the onset of winter inhaled in a tram while passing the city cemetery, a feather floating in the air at the level of an

${ }^{149}$ 'Laederach mit Roth über Roth', Basler Nachrichten, No. 277 - 24 November 1973. It is interesting to compare Roth's observation here with a comment made by the San Francisco poet, Michael McClure, in Roth's novel, Der große Horizont, which appeared in 1974: 'Van Gogh war nicht schizophren. Er hat die Dinge nur zu lange angestarrt. Die Farben, wie merkwürdig, daß es Farben gibt. Die Farben waren heilige Tinkturen für ihn' (Horizont, p. 56). 
upper-storey window, odd trains of thought arising in the mind while drinking with friends in a Graz café - such are the mundane starting-points for Künstel's perceptual adventures. The suspension of the usual rational judgements and habitual explanations which otherwise anchor such events firmly in the context of a familiar social reality, is achieved through the interaction of logically unrelated fragments.

Künstel's icy detachment from himself and his environment produces sentences expressive of a tranquility which appears artificial because it conflicts with the reader's growing sense of Künstel's illness. Although repeatedly mesmerised by the accumulation of intriguing and often poetic fragments, the reader also feels disturbed. Through the darker images of the text, there arises a sensation of claustrophobia and growing menace. A violent eruption threatens to occur. The sight of Lotschak's brain bursting open, the pain in Künstel's head, his rage with Lotschak, the appearance of the gentleman with the raspberry-coloured cape and the impeccable yellow teeth, the storm that blows into the room, the opening up of the 'Erdspalt' - these and related incidents explode at the close of the narrative into Künstel's sudden, murderous knife-attack on his landlady.

\subsubsection{Der Wille zur Krankheit}

In retrospect, Künstel reads like a preliminary exercise for the longer narrative, Der Wille zur Krankheit. In Wille the theme of an incipient schizophrenic breakdown is treated more extensively and with greater descriptive care and precision. While Künstel has about it the quality of an elaborate surrealist joke, Wille enters somewhat more seriously into the question of the relationship between illness and an increased sensitivity of perception. In the fragment 'Philosophische Gespräche', Künstel had asked himself the question: 'War nicht alles so, wie es war, weil er wollte, daß es so sei?' ( $M B M$, p. 259). Asked by Laederach to comment on this suggestion that such bizarre experiences could be interpreted as the product of a deliberate act of will, a notion which Roth's critics could conceivably use to undermine the view that valid aesthetic insights can be won from irrational states, Roth replied: 'Ich habe diesen Satz als Frage formuliert. Schon Wilhelm Waiblinger läßt in seinem Buch Friedrich Hölderlins Leben: Dichtung und Wahnsinn, die Frage aufkommen, wie weit der Zustand Hölderlins nicht mit einem Willensakt verbunden war. Diese Frage scheint mir nicht unbegründet. Im Willen zur Krankheit bin ich ja genauer auf diese Frage eingegangen'. ${ }^{150}$ In Wille, Roth allows the irrational to intrude

${ }^{150}$ 'Laederach mit Roth über Roth'. 
steadily, without obvious drama, into the framework of Kalb's otherwise ordinary existence until, finally, the accretion of the pathological in his life is such that he surrenders gladly to the feeling that he is in fact ill: "Als er das Gefühl des Krankseins in sich zu erkennen glaubte, empfand er eine eigenartige Genugtuung' ( $M B M$, p. 341).

An answer to the question as to whether Kalb's illness is the result of circumstances beyond his control or the product of a conscious 'Wille zur Krankheit' is not clearly indicated in the text. Symptoms of his illness are already apparent in the opening section, 'Was bisher geschah', before Kalb himself notes: 'Die Symptome von Krankheiten ... müssen als Kunstwerke betrachtet werden' (MBM, p. 313). By putting this statement which encapsulates the aesthetic programme of Wille into the mouth of a figure who is already showing signs of a schizophrenic breakdown, Roth avails himself of an ironic form of literary self-defence against the predictable objection of realistorientated critics that such an attitude to the pathological is itself mad. At the same time, he reveals that his real concern here is not, as it is elsewhere, with the social isolation and unsympathetic treatment suffered by victims of this crippling mental illness, but lies rather in harnessing the aesthetic potential latent in certain forms of schizophrenic experience as a means of attaining and expressing new literary insights into altered states of consciousness. Out of his knowledge of the aetiology of the disease, Roth constructed for himself a linguistic probe:

Sie ist die Basis für literarische Inventionen, die sich nicht mehr an die herkömmliche Sehweise halten müssen. Schizophrenie bedeutet für ihre Beschreibung die Notwendigkeit, oder, literarisch gesehen, die Lizenz, von verstandesmäßig glatt einsehbaren Sätzen abzuweichen, Bilder, Metaphern, Verknüpfungen zu suchen, deren Außerordentlichkeit dem ungewöhnlichen Geisteszustand Kalbs entsprechen. ${ }^{151}$

Although critics would repeatedly overinterpret the degree of social comment present in einstein, Künstel, and Wille, in his own mind Roth was clear that he wished initially to proceed 'ohne auf soziale Bezüge einzugehen': 'Das sind doch alles Klassifizierungsidioten, dachte sich Kalb, als er aus dem Fenster über die Dächer der Stadt schaute' (MBM, p. 316).

${ }^{151}$ Drews, 'Haid setzte die Brille wieder auf ...', Laemmle and Drews, p. 37. 


\subsubsection{Der Ausbruch des Ersten Weltkriegs: ein Spionageroman and How to be a detective: Ein Kriminalroman}

The predominant motive force behind the two remaining 'Kurzromane' of the early period is Roth's interest in exploring for himself the aesthetic possibilities latent in such avant-garde literary techniques as montage, permutation, and the parody of popular genres, with only minimal reference to everyday life. Der Ausbruch des Ersten Weltkriegs: Ein Spionageroman and How to be a detective: Ein Kriminalroman were written in the early months of 1972 while einstein was being prepared for release. They represent little more than accomplished finger exercises in Roth's literary development. This fact was not overlooked by critics but, as many reviews also confirm, these two eminently playful texts exercise a certain charm and fascination which succeed in holding the reader's attention. They also provide evidence of the way Roth received ideas and techniques used by the 'Wiener Gruppe' and earlier avantgarde experimentalists.

The method of narrative organisation is the same as that which Roth employed in Künstel. Both texts consist of a series of fragmentary scenes conveyed in short paragraphs and expressed in language of the utmost grammatical simplicity. The usual reader expectations of the spy-story and the detective novel, the two genres whose logic Roth is subverting here, anticipate a suspenseful progression from initial disorder - the threat of chaos or an actual crime - to a denouement of some kind and the subsequent restoration of order. In both instances, Roth frustrates this expectation. The threads of his spy-story are from the outset inextricably entangled in a phantasmagoric vision of Austrian society in chaos on the eve of the First World War. His miniature detective novel explodes the time-honoured notion of the signifieant clue, goes rapidly nowhere, and ends with the murder of the detective.

The montage units which Roth uses in the construction of Ausbruch are literary quotations. From Joseph Roth's story, Der stumme Prophet, and Giuseppe Tomasi di Lampedusa's novel, Der Leopard, he takes a series of sentences and figures which provide the basis for his own text. Combining and recombining these narrative elements in groups of half-a-dozen or more paragraphs, he creates 56 vignettes which span the period from 1908-1914. In a light-hearted and ironic postscript in which he quotes (or pretends to quote) from a letter written to his friend, Königshofer, the author describes the narrative effect at which he is aiming: 'Der Text soll wie eine Folge von Farbbildern wirken, die man durch ein Schlüsselloch erspäht. Infolge der starren Perspektive sieht man immer nur einen Teil des Geschehens'. In fact, events are viewed not just through one, but through a series of such keyholes. The assemblage of quoted fragments creates in the mind of the reader flickering images of life in pre-1914 Imperial Austria, a literary effect 
analogous to the screen-images produced by the hand-operated cameras of the early silent-film era. One-dimensional personages oddly detached from $\mathrm{Der}$ stumme Prophet - Herr Parthagener, Herr Kapranek, Dr. Derschatta, and Frau Tarka - mysteriously appear and disappear together with the distinctive paraphenalia of the period: pinz-nez, top-hats, canes, pocket-watches, spats, drawing-rooms, bathing-cabins, and luxurious train compartments.

Roth's use of montage in Ausbruch was stimulated in part by his interest in the montage experiments conducted by members of the 'Wiener Gruppe'. Of particular interest to Roth was the work of Konrad Bayer. The prose text Der Kopf des Vitus Bering, ${ }^{152}$ perhaps the most intriguing and accomplished of Bayer's experiments with montage techniques, had been published posthumously in 1965. This complex narrative centres on the historical figure of the arctic explorer, Vitus Bering (1680-1741). Bayer constructed the text principally out of quotations taken from documents relating to Bering's explorations and studies of shamanism. The result is a trance-like vision of Bering's arctic voyage and eventual death from scurvy after a shipwreck. Roth was familiar with Der Kopf des Vitus Bering and other Bayer texts when he wrote Ausbruch. Whereas his previous experimental works had derived their literary form largely from writings on and by the mentally ill, Roth now turned his attention to specifically literary sources. His use of pre-existing material in Ausbruch does not aspire to the thematic depth of Bayer's text which is attained through the use of subtle semantic feed-back between the montage elements. By repeating and varying his montage units and linking them through a minimal plot to the central figure of Bering, Bayer produced a textual unity which does much to consolidate his efforts to articulate shadowy and atavistic areas of the collective unconscious. Der Kopf des Vitus Bering was constructed with painstaking attention to detail and it took Bayer several years to bring it to completion. In contrast to the brooding twilight depths of Bayer's montage, Ausbruch is an entertainment, a mercurial literary curiosity. In this kaleidescopic period piece, it is clear that Roth is interested above all in trying out for himself the narrative perspective offered by a cut-up style of montage.

The title, 'Der Ausbruch des Ersten Weltkriegs' is deliberately misleading as is the subtitle, 'Ein Spionageroman'. The title leads the reader to assume that the well-known events leading up to the First World War are occuring in the background. In the text, however, they receive no mention. The motives of some of the suspicious figures who flit in and out of view may or may not be espionage. Any possible continuity of action is anarchically disrupted by the rapid shift to a further, logically unrelated series of events. As in all of his early work, Roth delights in exploiting grotesque and surreal possibilities. Here they are latent in the elaborately wrought material trappings of Imperial Austria. As

${ }^{152}$ K. B., Der Kopf des Vitus Bering, (Olten and Freiburg, 1965). 
the beloved flea-market 'objets trouvés' of classical surrealism, these characteristic and status-laden possessions of the well-to-do automatically suggest a surreal atmosphere to many readers in the later twentieth century. As the basic material culture on which early surrealist art and literature was erected, they now appear to us as familar and yet still encrusted with some of the strangeness which Max Ernst, André Breton, and other surrealists attributed to them. Transported from their natural historical and literary setting, in the context of sentences appropriated from Joseph Roth and Lampedusa these objects become larger than life: 'Zwischen zwei Fingern hielt T. den Zwicker, der an einem breiten schwarzen Band festgeknüpft war, drohte mit ihm, zeichnete mit ihm verschlungene Ornamente in die Luft $(M B M, \mathrm{p} .273) \ldots$ Kapranek trug einen sandgelben Überzieher, rötliche Handschuhe, eine hellbraune Hose, auf dem Kopf eine braune Melone. In der Hand hielt er ein Köfferchen mit kleinen Fläschchen Kölnischwasser, mit der anderen zog er energisch an der Glockenstange' ( $M B M$, p. 279).

The swift progression of images, accelerated by the staccato effect of parataxis, reduces the characters of the original narrative to comic-grotesque caricatures. The key-hole perspective and the dropping away of the internal and external logical and textual connections usually conveyed through qualifying subordinate clauses, serve to uproot these short scenes from their historical social context. Freed from subordination to a realistic or even logical narrative scheme, they float disembodied and linguistically effervescent through the text to burst as tantalising semantic bubbles in the reader's imagination. Without entering deeply into the phenomenology of the act of reading, it would appear that the readability of Ausbruch must be attributed in part to the visual sophistication of readers in the second half of the twentieth century. Familiarity with the image-manipulative techniques of cartoon animation and experimental film, pop-art and advertising is an indispensible facet of general literacy amongst Roth's generation. Daily exposure to images of realistically 'impossible' events through the media, helps to bring a sense of readability to Roth's otherwise illogical anti-narrative. Readers who are not innately hostile to the idea of actively participating in the opportunities for aesthetic play provided here by Roth's variations on the well-known game-rules of the spy-story, can reconstruct for themselves from the information provided, the moving coloured pictures Roth had in mind. Approached in this way, Ausbruch can be seen to offer a narrative which flows according to the visual logic made familiar to us by film and video animation. Roth does not employ in Ausbruch any technique which is not already an established convention of some other medium. On a closer reading, it becomes apparent that the pleasure of the text lies not so much in its wilful deformation of the everyday, as in the subversion of the conventions of a popular literary genre. 
In How to be a detective, the strict deductive logic of the detective novel is dissolved in the fantasy world of Inspector Potter. Potter pursues whimsical notions and stray perceptions with a detached curiosity and throws out the window objects which any conventional detective figure would regard as vital clues. Potter's observations are bizarre and illogical. The normal process of narrowing down the evidence is reversed. Details accumulate and overwhelm the search for a rational thread: 'Der Wäschekasten stand weit offen. Der Kommissar entfernte eine Parkette aus dem Fußboden und warf sie aus dem Fenster. Er entdeckte den toten Nachtfalter und versteckte ihn unter dem Hutband. Wo aber befand sich der Schlüssel? Erschöpft öffnete er die Fensterläden. Eine Wolke gelber Schmetterlinge strömte in das Zimmer' (MBM, p. 290). Like the key referred to in this passage, the key needed to unlock the meaning of the mysterious events Potter encounters and initiates, is never found. Corpses continue to accumulate and the Inspector feels that he himself is being pursued: 'Potter beschleunigte seine Schritte. Wer folgte ihm? Er konnte keinen Verfolger ausmachen' ( $M B M$, p. 295). In the sixty-ninth and final short episode, subtitled NACH VIELEN JAHREN, the Inspector is shot dead in the street. Whether it was the proprietor of the pet shop or the man with the lemonyellow face or a complete stranger, is of no consequence.

Manipulation of genre conventions to achieve new and sometimes startling narrative perspectives is not uncommon in the work of the Graz authors. Handke, for example, had already experimented with the game-rules of the detective novel in Der Hausierer. In Die Angst des Tormanns beim Elfmeter, he draws on the narrative model of the thriller. Bauer's dramas frequently involve a subversive parody of established conventions with comic-grotesque results. In Die Klosterschule, Frischmuth produces a narrative which is based on a deconstruction of the autobiographical girls' school story. Jonke's treatment of the 'Heimatroman' in Geometrischer Heimatroman has some parallels with Handke's Der Hausierer. In Ausbruch and How to be a detective, Roth exploits the same genre as Handke but with very different results. The effect of Roth's texts is closer to Bauer's riotous one-acters than to Handke's serious and contemplative narratives. Handke withholds the causal connections between events in Der Hausierer as Roth does in How to be a detective. Their purpose is, however, very different. Handke is interested in regaining the genuine emotional impact of the original human experiences of fear, anxiety, paranoia, dread, and oppression which the unreflective repetition of the detective-genre formula has obscured in the course of time. In Der Hausierer, he patiently dismantles the linguistic framework of the genre in the hope of using the descriptive techniques he isolates in the process to once again depict the real experiences the genre itself has lost sight of. Roth, on the other hand, atomises the detective story to produce a hallucinatory effect. His aim is to liberate its inherently surreal and fantastical elements by parodying the realistic 
intentions of the detective story and turning its long-established conventions upside down. For Roth the surprises are aesthetic - the discovery of bizarre and delightful moments where no such such surprises were normally permitted to enter:

Prächtig wölbte sich das Firmament in Form einer Parabel herab. Der Kommissar betastete, während er eilends dahinschritt, den falschen Bart. $\mathrm{cm}^{2}$ um $\mathrm{cm}^{2}$ verschlangen die langsam dahinkriechenden Ziegelhäuser das Trottoir. Der Tierhändler ölte den 38er Trommelrevolver. Die Brillanten an den Fingern glitzerten. Er vernahm unmittelbar hinter der Diele ein verdächtiges Geräusch. Jemand lauerte hinter dem Polsterstuhl. Er hatte ja Zeit (MBM, p. 304).

What links the work of both these authors on the detective form to the genre experiments of other 'Grazer' is the attention they give to the way the genre and by implication our experience of its 'reality' - is constructed. Each in his own way dismantles the genre's component linguistic elements to reveal unexpected connections between language and experience.

In post-war Austrian literature, the attack on the naive realist mode begins in earnest with the 'Wiener Gruppe'. In the case of Roth, his reception of Bayer's work played an important but not exclusive role in helping him to become aware of the aesthetic and epistemological potential released through the unlocking of hitherto rigid genre rules. The already published genre variations of other young Graz authors undoubtedly also encouraged him in this direction.

\subsubsection{Lichtenberg}

Before moving on to write his first full-length novel, Der große Horizont, Roth carried out one further experiment involving an anarchic reversal of normative concepts of sanity and madness, this time in a piece written for the stage. Roth's first drama, Lichtenberg, premiered on 19 October 1973 as a part of Graz's sixth 'Steirischer Herbst' avant-garde festival. Roth conceived of the play as a 'Modell einer Unterdrückung durch Sprache und Klassifizieren' ${ }^{153}$ The full title of the original stage production is 'Lichtenberg oder die Unmöglichkeit der Naturwissenschaft'. A certain Herr Wenzel presents to a Professor his cretinous son, referred to only as the Object, as a subject for experimentation and possible transformation into a normal human being. A widow is mysteriously murdered and the Professor does his utmost to heap

${ }^{153}$ Roth quoted in 'Schüsse aus dem Dunkel' (anon.), Der Spiegel No. 44, 29 October 1973, pp. 169-170 (p. 170). 
suspicion on the defenceless Object until he is himself finally unmasked as the murderer. Completely unhinged by the experiments the Professor has carried out on him, the Object shoots his tormentor. Roth's scurrilous Professor resembles the historical Göttingen Professor, Georg Christoph Lichtenberg, only in so far as he utters some 25 of Lichtenberg's aphorisms in the course of the play. Roth notes that 'Es ist ja kein historischer Lichtenberg, der da auftritt, sondern ein Sprachmächtiger' ${ }^{\text {154 }}$ The play's central theme is expressed in the aphorism which precedes the list of dramatis personae: 'Da der Mensch toll werden kann, so sehe ich nicht ein, warum es ein Weltensystem nicht auch werden kann'. Every production to date has presented Lichtenberg within the tradition of the Theater of the Absurd.

The Professor is a comic-grotesque figure who, like Fritz Lang's Dr. Mabuse, believes that he possesses enormous scientific power over life and death. The essential impetus for Lichtenberg stems from Roth's intense interest in Büchner's Woyzeck. The parallels between the long-suffering Woyzeck and Roth's Object are, however, too crudely drawn in this first play to be described as an adequate literary response to the moral complexity of Büchner's drama. Comparisons with Handke's 'Sprechstücke', Kaspar and Das Mündel will Vormund sein, also tend to place Lichtenberg in an unfavourable light. Lichtenberg reveals neither the depth of reflection nor the dramatic ingenuity of Handke's plays. The stage directions indicate that the comic-grotesque, absurdist elements are intended to predominate. The Object is a clown-figure who attempts to defend himself against the brutal 'rationality' of the Professor. Roth returns to this theme with greater success in the later 'Kurzroman', Circus Saluti. In deciding to incorporate the aphorisms, Roth was clearly attracted by Lichtenberg's genuine wit and strong instinct for the irrational elements at work in human thought and behaviour along with his suspicion of all grand schemes and heroic figures. The play's focus on language as an instrument of oppression can be seen as a response to the interest of other Graz authors, particularly Handke, in the power which language confers on the unscrupulous who use their linguistic mastery to exploit and control those whose command is limited. The Object's blind revolt against the Professor and his final resort to the language of pure violence (Roth: 'Auch Schießen ist eine Sprache') is intended to be seen as a desperate attempt to communicate his acute suffering to a world obsessed with mere labels and not the reality behind them. Unfortunately the play provides insufficient thematic depth and lacks the dramatic development to be received as a serious critique of the abuse of language. It is not lacking in humour but Roth relies too heavily on effects that are merely grotesque and farcical.

${ }^{154}$ Roth quoted by Gerd Jäger, 'Wird jungen deutschen Stückschreibern das Leben zu schwer gemacht?', Theater heute, 1 (1974), pp. 33-37 (p. 34). 


\subsection{THE LONGER NARRATIVES: 'ICH WILL EIN ERZÄHLER SEIN'}

The publication of the 'Kurzromane' established Roth's initial reputation as a young 'Grazer' of considerable talent whose further literary progress should be watched with interest. Their reception by the press and other media was largely positive. ${ }^{155}$ At the popular level a comment like the following on die autobiographie des albert einstein is representative: 'Das Buch bietet Krimi, Horror, Parodie, Sprachexerzizien zugleich. Es ist ein Lesegenuß für zwei schöne Stunden. Hier debütiert ein Talent. Irgendwie scheint der Name Roth für Qualität zu bürgen'. ${ }^{156}$ More academically orientated critics like Drews found greater originality in einstein and Wille and viewed the other texts more as accomplished diversions. Drews, for example, notes of Ausbruch that 'seine Begabung nicht so sehr beim spielerischen Aufgreifen von bekannten Erzählformen liegt. Vielmehr verlangt ihm offenbar die Herausforderung durch anormale, außerordentliche Geisteszustände sein Bestes ab' ${ }^{157}$ Ria Endres confirms this view in her later comments on Wille: 'Trotz des Grauenhaften, des Abstoßenden liegt der Hauptakzent ... auf dem Wort Ästhetik. Roth will nicht den Bürger schrecken, er will ihn aufmerksam machen und ihn zum Anschauen der künstlerischen Künstlichkeit verleiten'. ${ }^{158}$

Early in 1973, some months before the premiere of Lichtenberg, Roth experienced a period of crisis in relation to the future development of his work. He began to feel that he had written himself into a corner from which he did not immediately know how to extricate himself:

Ich bin mir vorgekommen wie in einer Blackbox, in einer schwarzen Schachtel mit einer winzigen Öffnung, durch die ich auf Gegenstände und meine Umwelt blicke, die ich ganz mikroskopisch betrachte, und ich habe einfach Sehnsucht gehabt, sozusagen die Fensterläden aufzumachen und größere Ausschnitte einzufangen. ${ }^{159}$

He realised that the nature of the works he had produced so far was essentially introverted. He had been rejoicing in the power of his own wilful subjectivity to fictionally subvert the ideas and experiences on which the conventionally ordered world based its sense of normality. As he later noted of his early

\footnotetext{
${ }^{155}$ See also pp. $72-73$ above.

${ }^{156}$ W. Christian Schmitt, Darmstädter Echo, 21 April 1972.

157 'Zur Ablenkung geht Künstel ins Kino', Süddeutsche Zeitung, 3/4 February 1973.

${ }^{158}$ 'Durch Bilder waten: Gerhard Roths Prosa und Stücke', Deutsche Zeitung, 18 May 1979.

${ }^{159}$ Sigrid Esslinger, 'Gerhard Roth: Ein neuer Morgen', Bayerischer Rundfunk (Television), broadcast 23 May 1976, transcript, pp. 4-5.
} 
'subjektive Phase', it had been 'ein Genuß schwer verständlich zu sein, weil ich mich auch nicht verstanden gefühlt habe' (Interview 1):

Was die frühen Arbeiten betrifft, bin ich bei diesen Arbeiten von meiner eigenen Subjektivität so stark gefangengenommen, daß ich sie als Ausdruck eben meiner Situation innerhalb der Gesellschaft, in der ich gelebt habe, und lebe, sehe, und auch meiner Beschränkung innerhalb der Gesellschaft, so daß ich mir sozusagen fast das Tarngewand des Schizophrenen angezogen habe, also, meine Ver-rücktheit, meine Verschobenheit, Ausdruck gefunden hat ... Auch das halte ich für eine Form von subjektiver Revolution, über die man geteilter Meinung sein kann, aber die mir in dieser Phase meiner Entwicklung als einzig mögliche Form mich auszudrücken zur Verfügung gestanden hat (Interview 1).

He had enjoyed a highly successful period of apprenticeship to language and avant-garde literary techniques. His skill in generating unusual narrative perspectives had won him the approval of a small group of 'literary fans'. It was the very technical expertise behind these works which now struck him as restrictive: 'Ich habe gemerkt, daß ich Bücher fabrizieren konnte. ... Ich wollte nicht länger reagieren wie ein Fotoapparat, der bloß registriert und abbildet' ${ }^{160}$ The creative sterility of trying to continue in this vein was obvious: 'Ich hätte in dieser Form weiterschreiben können, jeden Tag ein paar Zeilen, aber im Prinzip ist es mir in diesem Stil immer schwerer geworden, weil sich ein gewisser Wortrepetismus in mir gebildet hat: auf bestimmte Wortkonstellationen war ich schon fähig zu reagieren. Das war schon wie ein chemischer Prozeß' (Interview 1). The sophisticated avant-garde game-rules with which Roth had been experimenting imposed on his work a number of limitations. The specialisation and restricted communicative range of the early 'Kurzromane' stemmed not only from his initial insistence on the principle of extreme subjectivity: avant-garde works by definition communicate only with small, specialised, even elitist audiences. In reply to a question about the nature of his early readership, Roth commented:

Meine Leserschaft kenne ich besser als Zuhörer bei Lesungen. Dort sind es in erster Linie Schüler und Studenten. Ich schreibe natürlich nicht bewußt für Schüler und Studenten. Ich will auch sagen, daß meine Leser sicherlich "literarisch progressiv" sind. Es stellt sich mir aber die Frage, ob ich damit nicht eine Literatur produziere, die als elitär zu bezeichnen ist. Mein

${ }^{160}$ Ulrich Greiner, 'Ich will ein Erzähler sein: Porträt des Schriftstellers Gerhard Roth', Frankfurter Allgemeine Zeitung, 29 December 1976. Reprinted in Der Tod des Nachsommers, pp. 158-163. 
augenblickliches Bedürfnis nach Einfachheit ist zum Teil eine Folge dieser Überlegung. ${ }^{161}$

A fascination with the aesthetic machinery of all-too-literary forms of writing, coupled with the capacity of the immature ego to indulge endlessly in its monomaniacal power to fantasise, can lead to a purely narcissistic form of literary production. The link between imagination and the ground of experience stretches to breaking point.

Critics of the volume Der Ausbruch des Ersten Weltkriegs in particular, were not slow to point out the dangers of continuing in this direction: 'esoterisch ... Auch dieses Buch dürfte es schwer haben, einen breiten Leserkreis zu finden'; ${ }^{62}$ 'Auf die Dauer wird es Roths Lesern nicht genügen, daß er ihnen nur Brocken und Brösel hinwirft' ${ }^{163}$ Until now, the fictions Roth created had not connected in any vital way with the social nexus. Nor had these works touched on many vital areas of his (auto)biographical self. He now saw that they represented 'ein[en] Versteckprozeß vor mir selbst' (Interview 1). He had explored to his satisfaction the aesthetic possibilities which arise when events are viewed from the extreme edges of rationality and felt that in Wille he had taken the theme of schizophrenia as far as he profitably could. Roth now felt strongly the need to create characters and situations with which he and his readers could positively identify. In no sense of the word were einstein, Künstel, or Kalb substantial characters. As a means of establishing communication between Roth's inner consciousness and the external social sphere they were inadequate. Further, the narrative strategies he had developed were mainly suitable for shorter works. They could not provide the narrative coherence required of a sustained epic construction. At the same time, Roth did not wish to fall into the trap of conventional realism. He was searching, instead, for a way to maintain an experimental approach to literature:

Es wird vielleicht von Außenstehenden, von bestimmten Kritikern diese erste Phase von mir eher als 'experimentell' betrachtet, und die zweite Phase als 'konservativ', um zwei mögliche Ausdrücke zu nehmen, aber für mich ist jedes Buch experimentell. ... Ich könnte niemals sagen, so jetzt habe ich meinen Stil gefunden und jetzt mache ich zwanzig Bücher damit, sondern ich versuche immer neue Methoden anzuwenden, wenn sie vielleicht auch im ersten Augenblick nicht einsichtig sind (Interview 1).

Roth had passed through what he later came to regard as his own enactment of the process of the post-war Austrian 'Sprachreinigung'. Above all, he was now

\footnotetext{
${ }^{161}$ Bloch, p. 335.

${ }^{162}$ Hans Dieter Schmidt, 'Experimente aus Österreich', Maï Echo, 1 December 1972.

${ }^{163}$ Kurt Kahl, 'Nicht auf Dauer', Kurier(Vienna), 2 January 1973.
} 
anxious to arrive at a literary strategy which would enable him to engage in die Beschreibung meines Lebens in meiner Zeit (Interview 1).

Roth's literary development corresponds to the pattern followed by other Graz authors: a relatively short apprenticeship to the more extreme forms of avant-garde experimentalism gives way to works which endeavour to incorporate more of the surrounding social space: 'Das spezifisch Österreichische an meiner Literatur ist also dieser Entwicklungsprozeß, der von 1945 bis jetzt [1980] stattgefunden hat, d. h., die Beschäftigung mit sprachlichen Formen, wie in den früheren Arbeiten, Beschäftigung mit experimenteller Literatur meine Form der Sprachreinigung sozusagen - und die Zuwendung zur Beschreibung meines Lebens in meiner Zeit, nachdem ich mir die sprachlichen Mittel erarbeitet habe' (Interview 1). In this second phase, examples of 'Grazer Literatur' begin to take on a specifically Austrian social context. In Die Klosterschule, Frischmuth attacks repressive aspects of the Austrian Catholic school system. The narrow spiritual and ideological confines of the provinces are exposed by Jonke in Geometrischer Heimatroman. For the first time in his work, Handke includes much that is specifically Austrian in Die Angst des Tormanns beim Elfmeter. Bloch, the protagonist, is the goalkeeper of a professional football team. Vienna and a provincial village provide the setting and Handke includes considerable detail of lower middle- and working-class life in the Second Republic. In Wunschloses Unglück, a directly biographical text, Handke confronts the effects of the Nazi era and the suffering inflicted on his mother through the rigid adherence of her family and other villagers to a negative Austrian provincial mentality. Although allegorical in form, Kolleritsch's novel, Die Pfirsichtöter, is a critique of hierarchical processes of social conditioning in post-war Austria. In Die grüne Seite, Kolleritsch traces the conditioning process a generation further back, this time in a realistic and detailed social setting. Kolleritsch argues that we compulsively repeat that which has already been thought in the past. The grandfather, an 'Oberlehrer', attempts to save his son Gottfried from this destructive process by apprenticing him to Nature. As he explains to a school inspector: 'Die Erziehung ist die goldene Schnur, wir hängen an ihr, sie gibt uns, das ist nicht abzuleugnen, den Mut durchzuhalten, damit wir sein können, was wir sein müssen. Wir haben gelernt, die Macht anzuerkennen und mit unserem Ich zu repräsentieren, während wir draußen die Welt als tote Welt erleben oder als uns deformierendes Chaos. Doch alles da draußen, bedenken Sie das, Herr Inspektor, war einmal menschlich oder menschlicher' (pp. 53-54).

Unlike earlier works by Graz authors in which the existence of an everyday world behind the text can only be inferred, themes of clear contemporary social concern begin to be dealt with in an identifiable social context. These works can be construed as a burgeoning response to the virtual absence until the 1970 s of a literature prepared to confront issues arising from the experience of 
life in the new Austria of the Second Republic. The literary means employed are, however, far removed from the techniques of conventional realism. Parallels between developments in 'Grazer Literatur' in the early 1970s and the emergence of what has been labelled as a 'Neue Sensibilität' in German literature generally at the time are manifest. Examples of 'Grazer Literatur' like Handke's Die Angst des Tormanns beim Elfmeter, Wunschloses Unglück, and Der kurze Brief zum langen Abschied are as important as indicators of this 'Tendenzwende' as Peter Schneider's novel, Lenz, or Karin Struck's Klassenliebe, both of which appeared in 1973. The major difference is that whereas for many young West German or East German authors working predominantly in the realist mode, the associated 'Rückzug ins Private' involved the reaffirmation of subjectivity and personal experience as the necessary complement to abstract political theory, for the 'Grazer' it was largely a matter of forging workable links between avant-garde linguistic experimentation and their own historical situation by drawing on their experience of life in the Austrian Second Republic. Although both tend to produce the effect referred to by critics as 'Neue Subjektivität', the approach of the Graz authors to the dimension of 'das Erfahrene' is based on very different presuppositions about language and reality. Critics devoted to 'pure' political or experimental literature were quick to scorn the shift of emphasis: 'Sie erzählen doch wieder!' Certainly there were excesses - instances of excessive, merely sentimental, nostalgic or naively 'Wertherish' outpourings did occur in Austria as elsewhere. The standard of 'Grazer Literatur' during this second phase, however, remained remarkably high and the best works of the period represent a genuine shift in awareness both of the authors' self and the surrounding social space. The literary strategies created by Graz authors to achieve this end are many and varied.

For Roth in 1973, the process of shifting his attention outward from purely cerebral realms to consider his predicament in relation to the world in which he was living had only just begun. Firstly, he felt the need to create a central character with whom he and his readers could readily identify. Secondly, he had to produce a coherent narrative framework which would allow psychological depth and sustained character development without sacrificing to any predetermined interpretive scheme his 'neurotische Wahrheitsliebe' - his belief that good fiction must be based on precise and original observation. Above all, he was concerned to avoid the overinterpretation of events which he knew would inevitably result from the use of an established epic genre in the realist mode.

\subsubsection{Der große Horizont}

The external event which finally helped open the way to Roth's further development was an eleven-day trip to the United States of America. In 1972 
Roth was awarded a 'Literaturstipendium' by the Province of Styria and, early the following year, a state-funded 'Nachwuchsstipendium für Literatur'. In 1972 he drew on the 'Literaturstipendium' to travel for the first time to the U. S.A. with his fellow 'Grazer', Alfred Kolleritsch and Wolfgang Bauer. In March of 1973, he undertook a second visit to the U.S.A. with Bauer. The first of Roth's 'Amerika-Reisen' was necessarily brief. By now Roth held a responsible position at the medical computer centre. But, as is sometimes the case with such short journeys, the experience proved particularly intense. The trip marked the end of his first 'Schreibkrise'. The shock of the new and the unfamiliar in America awakened Roth's interest in the external social world. His attention was jolted out of its previous introversion and his unusually acute powers of observation and perception were focussed instead on the hard-edged realities of America's big cities, New York, Los Angeles, and Las Vegas. In less than two weeks, Roth filled several thick notebooks and took several hundred colour slides on a cumbersome Zenith camera. Although he later held a number of photo-exhibitions in Graz and elsewhere, Roth made no pretense at the time to being a professional photographer. He intended these exposures to be 'Fotonotizen', a visual complement to his copious written notes. The quality of many of these and later photographs provide substantial evidence of Roth's originality of mind and compositional ability. For almost a decade from 1973 up to his initial work on Landläufiger Tod, Roth continued to use the activity of photography as an aid to concentration. Photography helped him to become aware of what was actually there around him, to use what was immediate and not what was remote from his experience. The photographs themselves have played a significant role in Roth's method of narrative composition. ${ }^{164}$

Shortly before he travelled to America, Roth had already tried his hand at applying to the external world some of the descriptive techniques he had previously used to depict the world of the mind. In the context of his early journalistic activities, signs of a growing interest in the social dimension first appear in print towards the end of 1972. The carefully controlled use of the author's subjectivity is already perceptible in a number of articles written for Graz newspapers and Austrian literary journals. Actual events are described in sentences of remarkable clarity from the position of an observer who is detached and yet who remains intensely interested in what is occurring. Facts are related to subjective impressions in such a way that subtle distinguishing features otherwise flattened by conventional journalese, are able to emerge. In an article on the Viennese football coach, Leopold Stastny, for example, Roth begins by recording directly a number of Stastny's ideas and opinions. Remaining anchored in a laudable sense of fact but also heightening details to

${ }^{164}$ The effect of photography on Roth's two 'American' novels has been analysed by the present writer in his M.A. Thesis, pp. 81-82, pp. 87-88, and Appendix. See Note 102. 
an unusual degree, Roth proceeds to draw out those aspects of Stastny's character which make him the unusual personality suggested by the title, 'Eine Figur von Beckett'. ${ }^{165}$ Such instances provide early evidence of Roth's desire to facilitate the telling of the missing 'zweite Hälfte der Geschichte' ${ }^{166}$ which is left out of normative accounts. It is in the prose sketch, Italienischer Badeort, published in manuskripte early in 1973 ( $m$ 41, pp. 35-36) that there are indications of a significant change in Roth's approach to narrative form. As many of his fellow Graz authors had already done, Roth turned to a more traditional type of narration. The subjective, surrealistic elements are still present but the narrative perspective is consistent, events follow a linear sequence, there is a definite social setting and a narrator with whose impressions a wider audience can identify.

Even before he travelled to America, Roth had already attempted to plan a work which would enable him to reflect on 'die ihm fragwürdige Ordnung seines Lebens und die damit kontrastierende bizarre Verstörtheit seiner schriftstellerischen Versuche'. ${ }^{167}$ The sense of discrepancy between his orderly, largely conventional middle-class existence as a husband, father, and responsible employee, and the anarchic disorder of the psychological realms he had been exploring became acute. What he sought was a fictional vehicle which would help him to define and perhaps to break down some of the barriers between these apparently conflicting dimensions. His experiences in America now assisted greatly in the 'shaping of the outer world of action' which, in Roy Pascal's view of the German novel, helps to give the inner world its clarity and the protagonist's moral development its plasticity. ${ }^{168}$ In the summer of 1973, Roth set to work on the materials he had gathered in America.

Der große Horizont was published by Suhrkamp in the autumn of 1974. It is dedicated to Wolfgang Bauer. For copyright reasons Roth was obliged to drop the novel's original title, Kodachrome. The draft title reflects the strong visual bias of the narration and the fact that the story is constructed around a series of 'Momentaufnahmen' selected from the photographs he took on the journey. The published title better indicates the novel's theme - the protagonist's search in America for a new personal horizon. Handke's 'American' novel, Der kurze Brief zum langen Abschied, which offers interesting parallels and contrasts to Roth's novel, appeared in the Spring of 1972, over a year before Roth began work on Der große Horizont. A fascination with America in the late 1960s and early 1970 s is common to many of Roth's generation. Interest in American

\footnotetext{
${ }^{165}$ See $M B M$, pp. $46-48$.

166، Sehen Sie, es fehlt uns die zweite Hälfte der Geschichte, und diese zweite Hälfte ist meine Geschichte ..." Dalton to Weininger in Ein neuer Morgen, p. 155.

${ }^{167}$ Klaus Völker, 'Auf der Suche nach sich selbst: Gerhard Roths Roman Der große Horizont', Tages-Anzeiger (Zurich) 19 December 1974.

${ }^{168}$ R. P., The German Novel, (London, 1965), p. 303.
} 
detective fiction was also widespread. Stylistically the two novels are very different.

The central character in Der große Horizont is Daniel Haid, the thirty-eightyear-old proprietor of a Viennese bookshop. In the opening paragraph the reader is given a brief but comprehensive portrait of Haid. He is described as 'ein Mann mit poetischen und hypochondrischen Gefühlen'. He has scientific and literary interests and on the evening of his departure for America to visit Austrian friends there, he leafs through his notes 'über den botanischen Bau von Pflanzen, Anmerkungen zur Lektüre von NIELS LYHNE und zur Prosa der deutschen Romantiker, über den Sprung einer Katze aus einem Fenster und seine Gedanken über biologische Ernährung'. He is thus a man of some sensibility. His wife has recently left him for a lawyer with whom she had been having an affair. The separation has left him melancholy and suddenly aware that his youth has gone. He occasionally drinks too much and is uncertain in his feelings towards women: 'Er interessierte sich für sie, aber sobald er länger mit ihnen zusammen war, empfand er sie als Belastung'. The trip to America promises diversion and a break with the oppressive pattern of his daily existence. Getting up from his writing table, Haid experiences a moment of dizziness which foreshadows the confusion of the labyrinth into which he is about to descend.

The initial paragraphs of Horizont appear at first to be written firmly within the conventions of nineteenth-century realism. Roth's prose style is simple, precise, and capable at moments of disarming elegance. A sentence like the following might have been written by Fontane: 'Haid setzte die Brille wieder auf, wickelte die silberne Biedermeierzuckerzange, die er für Christine gekauft hatte, sorgfältig in Seidenpapier und steckte sie zwischen den Hemden in den Koffer' (p. 8). The references to Jakobsen's Niels Lyhne $(1880)^{169}$ and the prose of the German Romantics reinforce the appearance of a confident narrative realism. In the ensuing paragraphs which depict the flight to Zurich and Haid's arrival in New York, there is a curious passing resemblance to the opening pages of Frisch's Homo Faber (1957). Then, in the first reference to Philip Marlowe, the hero of Raymond Chandler's popular detective novels, Roth introduces a new and unexpected element: 'Während Haid zwischen den Backsteinbauten durch dichten Verkehr fuhr, hatte er den Eindruck sich selbst in einem Kriminalfilm zu sehen. Er dachte an Philipp Marlowe ...' (p. 9). ${ }^{170}$

In writing Horizont, Roth wanted to maintain an open-minded approach to the significance of the experiences undergone by his central character. He also wished to avoid losing sight of the outlines of his protagonist's individuality

${ }^{169}$ The Danish writer, J. P. Jakobsen (1847-1885), who translated Darwin's main works into Danish, was interested like Roth in both literature and natural science.

${ }^{170}$ Throughout Horizont Roth follows the German spelling of 'Philip' ending the name with a double 'pp' as it appears in the Ullstein edition of Chandler's novels. 
and of everyday reality amidst a welter of random perceptions as he had done in the 'Kurzromane'. He required a narrative strategy which would enable him to tread the fine line between a degree of formlessness unacceptable in a longer novel and the over-interpretation of the life-world to which he and others of the Graz Group were vehemently opposed. Both the personality and the environment of the central character had to be vehicles for further exploration and were to be interpreted as independently as possible of prevailing ideologies. In an interview given late in 1973 when he was working on Horizont, Roth remarked that he had recently become interested in the work of Raymond Chandler. His previous interest in the detective genre had confined itself to parodying the logic of the 'classical' type of detective story in How to be a detective. In Chandler's 'anti-classical' urban detective novels Roth found an important key to his structural dilemma.

At first glance, Der große Horizont might appear to be a variation on the type of the 'Entwicklungsroman' written in the realist mode. A critical stage in Haid's psychological development is portrayed against the background of a realistically presented America. Roth's adaptation of ideas derived from his reading of Chandler, however, introduces a complex series of reflections on the links between Chandler's fictional strategies and Roth's own views on the interrelatedness of reality and fiction. The presence of this reflective dimension makes itself felt in the opening section of the novel and undermines its apparent realism.

Haid's sense of identity has become so uncertain that he finds himself frequently at a loss as to how he should act or interpret what he experiences. At such moments he retreats into fantasies, imaginings, and self-projections, most of which are based on his exposure to literature or film. Central to Haid's intense inner life is the figure of Philip Marlowe. The references to Marlowe in Horizont fall into three categories: speculations about what Marlowe would have done or thought in Haid's situation, scenes in which Haid imagines himself acting out the role of Marlowe, and passages in which Haid reflects on the relationship between his own experience and the nature of the fictional world Chandler portrays through Marlowe's eyes. Recollections of Marlowe's thoughts and behaviour furnish Haid with a means of orientation in the unfamiliar and sometimes threatening world of America: 'Als Marlowe, ein Mann mit ebenso viel amerikanischer Erfahrung wie Skepsis, fühlt sich Haid für Augenblicke wenigstens etwas gesichert'. ${ }^{171}$ The concession which Roth makes to narrative realism is qualified and, in effect, subverted by the introduction of this series of links to another fictional character and his creator. In Haid's mind Marlowe also inhabits a world in which things are not necessarily what they seem. Part of Marlowe's role as a detective consists in challenging con-

${ }^{171}$ Claude R. Stange, 'Fremdes Labyrinth: Gerhard Roths Amerika-Roman', Basler Nachrichten, 28 November 1974. 
ventional interpretations of events. Thinking about Marlowe's perception of things helps Haid to come to terms with the strangeness of a world in which everything could, indeed, be other than it is:

Marlowe erlebte jeden Augenblick wie eine Neuentdeckung, als wüßte er von den Dingen nur das Aussehen und den Namen und nicht die Funktion, als müßte er sich jederzeit vorsehen, daß ein Stuhl kein Stuhl ist. Haid kannte diesen Zustand, in den ihn zeitweilig eine unberechenbare Stimmung brachte. Wie oft hatte er einen Kühlschrank, ein Klavier als etwas Fremdes empfunden, so als sagte ihm KLAVIER oder KÜHLSCHRANK nichts (p. 10).

Haid's experience here of a disturbing emptiness caused by momentary lapses in his ability to read the usual semiotics of the world around him is almost an exact opposite of the experience of Bloch in Handke's Die Angst des Tormanns beim Elfmeter. Bloch's incipient schizophrenia leads him to paranoid overinterpretations of the signs he encounters. He translates visual images into commands and prohibitions on which he feels compelled to act. Bloch's nausea is brought on by an overload of pre-conditioned symbolic meanings... In contrast, Haid experiences at times the strangeness of objects and events which temporarily elude the net of language and memory. He alternates between this state of perceptual and linguistic displacement and the feeling that everything is quite normal and familiar: 'An solchen Tagen erschien ihm alles vertraut und selbstverständlich' (p. 10).

Haid is struck by the resemblance between the actual America in which he finds himself and the image of American society he has absorbed from Chandler's novels. This leads him readily to associations between his experiences there and his ideas (not necessarily Chandler's) about Marlowe. Haid is predisposed towards anxiety and even paranoia and tends to interpret negatively much of what happens to him in America. Chandler's detective novels also express an essentially negative view of modern American society. Marlowe is a correspondingly anti-heroic figure, a man concerned with retaining what he can of his integrity while surviving in the same 'mean streets' Haid is now discovering for himself. Haid can readily identify with Marlowe but he also reveals that he is aware of the gap which exists between the historical author, Chandler, and his fictional creation. At one point he imagines that he sees Chandler himself standing in a crowd which has gathered around a man who has collapsed in the street:

Philipp Marlowe hätte diese Situation vielleicht anders erlebt, dachte Haid, aber Raymond Chandler, der ihn erfunden hatte, war Haid vermutlich ähnlicher gewesen als die selbst erfundene Figur. Diese Annahme kam ihm 
sogleich dumm vor. Was wußte er von Raymond Chandler? Der Gedanke ließ ihn sich Raymond Chandler als einen jener Menschen vorstellen, die den Epileptiker umringten, mit dem Gesicht eines versoffenen Archäologen und der schwarzen Hornbrille, interessiert und ruhig, den Epileptiker als neues Fundstück für Philipp Marlowe betrachtend. Haid hätte ihn gerne angesprochen, wenn er ihn unter den Menschen gewußt hätte ... (p. 23).

Roth uses the relationship between Chandler and Marlowe to highlight the analogy between Haid's undivided inner self and the persona he assumes when he plays at being Marlowe. Faced with the reality of the unpleasant scene going on in the street, Haid's conscience forces him to admit that he is probably more like the ordinary human being Chandler himself was. But even in this thought he catches himself going beyond the limits of his experience and suddenly feels disgusted with the falseness of his self-projections: 'Plötzlich kam Haid sich überflüssig vor. Was tat er hier noch. ... Hier vor dem Gestürzten stand er nicht nur aus Neugierde, sondern auch wegen dieser Scham, die ihn schlaff machte' (p. 23 and p. 24).

Haid's sense of shame stems from the fact that he has no positive sense of identity. The weakness of his self-image leads him to indulge repeatedly in unauthentic forms of behaviour, especially whenever he feels somehow threatened. Like Marlowe, he is prone to the feeling that his existence is superfluous, irrelevant to the day-to-day life of a society from which he feels alienated. In Marlowe he sees a fellow outsider, but also someone who has come to terms with his displacement. In selecting the figure of Marlowe as a focal point for Haid's existential problems, Roth makes an interesting comment on the anxieties of his own generation and their enthusiasm for figures from popular culture.

Chandler's novels represented a departure from the usual narrative conventions of the detective genre. His detective hero expresses interest in a great many aesthetic and social matters which are irrelevant to the final outcome of the plot. Marlowe's attitude to life is something much more complex than that of his fellow detectives. The literary quality of Chandler's work has received some critical recognition. It is the latent concern with existential questions in the Chandler model which Roth is able to expand. In Chandler Roth found an author who had already begun to use a popular genre to reflect more widely on human experience.

Marlowe embodies a number of Haid's positive qualities including his sensitivity and his tendency to view everyday objects aesthetically. But his fascination with Marlowe also has a negative side. In moments of anxiety, Haid compulsively projects an unauthentic persona arising from the desire to present to himself and others a perfect 'fictional' self. Roth himself has described Haid 
as suffering from 'Chandler Krankheit'. ${ }^{172}$ At the root of Haid's obsession with Marlowe is the overwhelming temptation to experience life through the eyes of a borrowed personality which he believes to be stronger than his own. His ability to compare his situation to that of a well-known fictional character helps him to gain insight into this self-deceptive psychological ploy. Haid despairs over the weakness which impels him constantly to produce false internal 'narratives' from his experience. He sees a direct parallel between his outer mask and the situation of a fictional character: 'Schliupfte er nicht immer in eine lächerliche, ungeschickte, harte, mitleidige, sensible, gekränkte, überlegene Erzählfigur, die an seiner Stelle die Erinnerung stets verzerrt berichtete. ... die ihn sich verhalten ließ, WIE EINE ERDACHTE FIGUR UND NICHT WIE EIN MENSCH' (p. 99). His desire to escape his emotional vulnerablity expresses itself as a longing for a Utopian absence of memory. In his attempt to experience himself anew in America, he is frequently troubled by associations with his past, especially by feelings of humiliation connected with his wife's recent departure. He envies Marlowe's capacity as a fictional character to encounter each moment of existence as a new discovery, untainted by association with anything that has gone before: 'Er hatte Schwierigkeiten zu vergessen, aber er wollte es lernen, wie eine literarische Figur vergessen konnte. Philipp Marlowe erinnerte sich nie an vergangene Fälle. Nie erinnerte sich Philipp Marlowe an etwas, was in einem anderen Buch bereits beschrieben worden war' (p. 148). Here life envies fiction and this has the undesirable effect of leading Haid further into a state of unreality, away from the possibility of experiencing himself as a spontaneous human being. At those moments when Haid's fantasies of himself as Marlowe collide with the unavoidable realisation that he is only play-acting, his detective persona collapses, leaving him even more humiliated.

Such a painful moment occurs in San Francisco when Haid imagines that he has seen a woman being murdered in an apartment across the street from his hotel room. At this stage his perceptions are so influenced by his fears and vivid imaginings that he is left uncertain as to how to interpret other people's behaviour. Moments before he has been indulging in a 'Marlowe' fantasy:

Er konnte sich vorstellen, daß er durch ein Fenster Zeuge eines Kriminalfalles würde, daß eine Pistole unter seinem Kopfkissen lag, daß er sich vorsehen mußte, wenn es an der Tür zum Hotelzimmer klopfte, daß er mit einem Hut auf dem Kopf als Philipp Marlowe auf der Straße ging, daß er auf die Leiche eines Juweliers im schwarzen Anzug mit goldener Uhrkette stieß, und daß er den Anblick des glatzköpfigen Toten, der unweigerlich Hitchcock ähnelte, poetisch fand (p. 25).

${ }^{172}$ Ulrich Greiner, 'Ich will ein Erzähler sein. Porträt des Schriftstellers Gerhard Roth', Frankfurter Allgemeine Zeitung, 29 December 1976. 
Haid feels compelled to investigate further what he has glimpsed from the window - not like Marlowe, in order to bring a criminal to justice - but because he needs to learn the truth about his own interpretation of the world around him:

Vor allem wurde ihm klar, daß er über sich selbst Gewißheit haben mußte. Er mußte wissen, ob alles nur Einbildung war oder ob er etwas Wirkliches wahrgenommen hatte. Noch nie hatte er sich so verzweifelt an die Wirklichkeit geklammert wie jetzt. Dieses ganze Ereignis mußte einfach außerhalb seines Kopfes stattgefunden haben (pp. 26-27).

When Haid finally knocks at the door of the apartment, he realises to his intense embarrassment that he has not witnessed a murder but a moment in the violent love-making of its inhabitants. Roth could not make more pointed the contrast between Chandler's Philip Marlowe and Haid's fantasy version of him. Marlowe's survival as a detective hinges on his ability to discriminate clearly between fact and fantasy and to create from his perceptions a verifiable image of reality. Haid, on the other hand, is carried away by the most fleeting of impressions: 'Seine Schwäche war, daß er sich zu schnell hinreißen ließ.... Er war kein überlegter Mensch. Bevor es noch dazu kam, Wahrscheinlichkeiten zu prüfen, war er ein Opfer seines Hingerissenseins' (p. 29).

Because he is adrift in America, more aware of what he is not than of what he is, Haid is acutely conscious of his lack of purpose. He envies the sense of meaning and purpose which enables Marlowe, in typical detective fashion, to organise his perceptions into a significant pattern. As Roth's experimental texts demonstrate, to perceive events without reference to a conventional scheme of interpretation leads both to aesthetic insights and to hallucinations. As the rational being Roth wishes to portray in Horizont, Haid cannot hope to find himself in the ontological vacuum which arises whenever he perceives objects or events without any apparent meaning: interpretations from Marlowe's highly ordered fictional world rush in to fill the semantic gap.

In Horizont, Roth further explores his own anxieties about the problem of meaning as in the following passage in which the uneasy nature of Haid's unstructured perceptions is contrasted with Marlowe's fixed scheme of interpretation:

Der Postkasten gehörte zu einem Haus, in dessen Garten sich ein Baum mit kleinen Zitronen befand. ... Haid konnte sich vorstellen, daß Philipp Marlowe das Haus mit dem Zitronenbaum nicht aus den Augen ließ... Für Marlowe würde diese Beobachtung voller Zusammenhänge sein. Chandler ließ ihn Ereignisse und Dinge sehen und für ihn bedeutungsvoll sein, während er die Bedeutung dem Leser erst im Nachhinein erklärte (p. 108). 
Haid does not know what the house with the lemon tree 'means' ('bedeutet'). Although he perceives it very clearly, he cannot relate it to anything in his own life. For Haid, such isolated perceptions become a source of an anxiety from which the fictional Marlowe is protected: what the latter perceives has been preprogrammed to unfold into a meaningful pattern. In contrast to Haid, Marlowe is relaxed because he 'knows' that his observations will eventually form a conclusive logical scheme. Marlowe is not troubled by an absence of meaning or purpose but finds instead that modern America is a fallen world, too full of criminal plots to be a safe or desirable place. Haid's 'real-life' perceptions are devoid of any such overall meaning. Instead of forming a logical sequence, each of Haid's perceptions triggers a chain of fantasy or memory: 'Jede Wahrnehmung war mit Phantasiegeschichten verbunden, die gleichzeitig mit dem Sehen abspulten' (p. 149). In a moment of discomfort he remembers the way his wife deceived him and is troubled by the thought that events also occur of which he is quite unaware and yet which have the power to change the course of his life: 'Er war für kurze Momente aus seiner eigenen Lebensgeschichte ausgeschlossen gewesen, indem er in etwas miteinbezogen war, wovon er nie Kenntnisse haben würde, das aber sein Leben völlig verändert haben konnte' (p. 109). Bombarded by perceptions whose real significance is unknown to him and perhaps unknowable, Haid imagines an ideal state in which the meaning of things might be directly apprehended. Contemplating the Manhattan skyline from a New York graveyard, he is reminded of an experience which occurred to him years before in Hamburg while viewing a painting by Caspar David Friedrich. The painting, a study of Greifswald, gave Haid the feeling that he was himself standing on the border between this world, 'das Diesseits', represented by the dark areas in the foreground of the picture, and some other form of reality, 'etwas Paradiesisches oder das Paradies selbst':

Als er das Bild zum ersten Mal gesehen hatte, hatte er sofort das Gefühl gehabt, daß er unmittelbar davorstünde, diese Grenze zu durchbrechen. Er stellte sich die Grenze nicht bildlich vor, aber er glaubte, sie als eine Mauer von harter Luft zu verspüren, die ihn von den Gegenständen und Menschen trennte (p. 201).

Haid speculates as to how he might break through this invisible barrier. The suggestion is made that all a priori judgements must be suspended if a personal truth is to be arrived at:

Er dachte sich, daß man diese andere Form der Wirklichkeit, wie sie Caspar David Friedrich sogar hatte malen können, vielleicht sehen konnte, wenn man nicht mehr sprach und nichts mehr hörte und die Augen schloß und seine Sinne erst dann wieder öffnete, wenn in einem nichts mehr als Er- 
innerungen waren, auf die man blicken konnte, wie auf panoptische Bilder. Man würde sie mit Interesse betrachten, ohne zu urteilen. Man würde sich nur für die eigene Wahrheit, die in diesen Bildern lag, interessieren (p. 201).

There is more than a hint of mysticism in these speculations. It would be wrong to interpret this as a direct affirmation of a metaphysical dimension on Roth's part but it is symptomatic of the openness of 'Grazer Literatur' that the possibility of 'another form of reality' is not dogmatically excluded as it was from so much of the politically orientated literature of West Germany in the 1950 s and 1960s.

Already in die autobiograhie des albert einstein Roth introduced the idea of 'DAS RATIONALE LEBEN ALS FORM DER MYSTIK, ALS ETWAS TRAUMHAFTES' $(M B M$, p. 211). Here he is well within Austrian literary tradition. There is a distinct echo of Robert Musil's contemplation of the relationship between the rational and the mystical in the life of an enlightened, scientifically grounded citizen of the twentieth century. As Musil noted in his diary: 'Rationalität und Mystik sind die Pole der Zeit'. Neither had Wittgenstein dismissed the mystical. For all his concern to rid philosophy of unneccessary complexities, Wittgenstein concluded that there was a legitimate need for a mystical dimension: 'Nicht wie die Welt ist, ist das Mystische, sondern $d a \beta$ sie ist' (Tractatus, 6.44) and 'Es gibt allerdings Unaussprechliches. Dieses zeigt sich, es ist das Mystische' (Tractatus, 6.522). A preoccupation with glimpses of a reality behind or beyond the conventional surface of the world also emerges from the work of other Graz authors. In many instances, there is in their work a pervasive suspicion that there are other ways of looking at the world which offer perspectives more real and potentially liberating than the consensus reality the 'Grazer' are challenging. The narrator of Handke's Der kurze Brief zum langen Abschied senses the possibility of another dimension - 'die andere Zeit' (KB, p. 25) - a Utopiàn spontaneity and directness of experience which tantalises him throughout his American journey. A contemplative turning inward in the search for a healing reconciliation and revitalisation of the relationship between the self and the world provides the major impetus of Handke's more recent works. In an essay, 'Warum ich schreibe', Kolleritsch describes his task as that of exposing the 'gedachte, erdachte Welt' as a system of images which we have been socially conditioned to enact. His quest is for a greater degree of awareness as to how this conditioning occurs and how it can be circumvented: 'die genauere, unverstelltere Welt suchen und die Erfahrungen'. ${ }^{173}$ In Die grüne Seite, Kolleritsch depicts the world as a 'camera' which photographs the images we project of it and ourselves and develops them into the appearances we take for

${ }^{173 ،}$ 'Warum ich schreibe', in Laemmle and Drews, pp. 85-87 (p. 87). 
reality. Hoffer's Bieresch are trapped in a world which has grown from their false explanations of life. At the same time they long to regain their true identity in the 'Ursprung' which they forever seek to regain and forever 'explain' themselves further away from. Their secret hope is that someone who listens to their endless recitation of the Bieresch traditions will solve the riddle of existence for them and break the spell of history. The text is peppered with extracts from the mystical tales of the Hasidim, from the Bible, as well as from many Austrian authors including Stifter, Kafka, Rühm, Wiener, and Handke.

The possibility that there exists a more real and truthful mode of experience places Haid in a dilemma. This new awareness relativises all the existing systems of thought to which he has so far been attracted. He becomes suspicious of the ways in which he has been conditioned to interpret the world. At the same time, he finds that he is unable to break down the barrier between these seemingly arbitrary explanations and the desired state of self-knowledge. One viewpoint can be easily substituted for another. Each reveals something concealed by the other. An inconsistent detail can give the lie to any one of them:

Er dachte in diesem Augenblick, während er vor dem Schnellfotoladen aufund abspazierte, daß alles mit der Einbildungskraft zusammenhing. Die Einzelheiten zerstörten immer die Weltbilder. Ein Weltbild war wie ein Fingerhut, den man auf die Welt zu legen beabsichtigte. Sobald man merkte, daß der Fingerhut zu klein war, tauschte man das Weltbild aus und sah plötzlich wieder etwas Neues, das sich ebenso bald wieder nur als ein Ausschnitt erwies. Hermann Hesse, Philipp Marlowe, Karl Marx, er konnte sie beliebig für sich sehen und denken lassen - für sich! Aber er wollte selbst Erfahrungen machen! - Er war süchtig danach, Erfahrungen zu machen (pp. 39-40).

The desire to experience life in one's own terms - 'selbst Erfahrungen machen' - is fundamental to 'Grazer Literatur'. Roth does not consider himself bound to any ideology but accepts that all systems of thought have useful insights to offer:

Meine Stellungnahme dazu ist, daß der Schriftsteller nicht der Handlanger irgendeiner Philosophie ist außer der persönlichen Philosophie des Autors. ... Eine Ideologie ist für mich ein Werkzeug und kein Käfig. ... Jede Ideologie hat ihre begrenzte Anwendbarkeit. Der Marxismus kann nicht sämtliche Formen des Menschlichen abdecken: dazu ist er nicht in der Lage. Er kann partiell den Wunsch nach einer sozialen Gerechtigkeit abdecken, aber nicht mein Gefühl der Trauer, der Freude, der Liebe usw. beeinflussen. Genau so ist es bei der Religion. Sie kann das Bedürfnis nach metaphy- 
sischen Projektionen abdecken. Der Autor darf sich nicht innerhalb einer Ideologie befinden wie in einem Käfig ... ich glaube, daß der Autor die Ideologien kennen soll und sie dort anwenden, wo sie ihm etwas bringen, sich aber den Ideologien nicht ausliefern soll. ... Für mich ist mein Leben auch gleichzeitig eine Form des Experimentes, eine Form des Teilnehmens, Leidteilens, des Freudeteilens, aber immer mit dem Versuch zumindestens Abstand zu halten und Distanz zu empfinden - Distanz zu empfinden zu dem, wie andere versuchen mir das, was ich sehe und erlebe, zu erklären. Ich möchte mir das erklären mit dem Wissen, das andere erarbeitet haben, dann doch selbst prüfen und versuchen dem, was ich schreibe, gerecht zu werden (Interview 1).

Not surprisingly, Haid's attempt to give certain events meaning by weaving them into the borrowed context of Marlowe's underworld adventures - ' $\mathrm{Er}$ konnte jede Geschichte mühelos mit Marlowe in Zusammenhang bringen' ( $p$. 149) - leads him into a series of absurd predicaments. At their centre is Haid's paranoiac fantasy that he is somehow implicated in the death of the girl, Carson, with whom he becomes involved in San Francisco. Haid becomes acquainted with Carson through his friend Mehring and eventually sleeps with her. When he wakes next morning, he finds her dead beside him in the bed. She has in fact died of natural causes. Haid, however, panics and forgets all about being Marlowe for the moment. He feels suddenly like a murderer and slips out of the role of the pursuer into that of the pursued. His flight from the imaginary consequences of Carson's death provides the motive for the introduction of the thriller element in the novel as Haid travels first to Las Vegas and then to New York. In his confusion he is convinced that an acquaintance, the ex-policeman, O'Maley, is actually following him in connection with an official police enquiry.

In Horizont, Roth establishes a relationship between Haid and Chandler's detective figure which illustrates the tendency of the insecure ego to project itself in the form of a persona or false self. Under stress this false self collapses leaving the subject humiliated and confused. The references to Marlowe, Chandler, and the American urban detective genre provide Roth with more than just a convenient means of structuring the plot. The triangular authorreality-fiction relationship created in the novel provides a fictional model which helps Roth to reflect on the actual relationship between his authorial self, his material, and his central character. The critical success of Horizont confirmed that Haid was a fictional creation with whom Roth and his readers could readily identify. The narrative strategy Roth employs enabled him to further his command of the novel form as a means of exploring his own experience and, at the same time, allowed him to reach a far wider audience than he had through the 'Kurzromane'. 
The clear, controlled prose of Horizont by itself signals that the novel is not the product of what a Spiegel journalist referred to as the 'Ich-Cult' practised by some younger German writers including Gabriele Wohmann in the mid1970s. ${ }^{174}$ Although Roth deals with extremely subjective experiences, his disciplined approach avoids any sentimental self-indulgence: it was for this reason that he had decided to use the Er-form. Roth has overcome the temptation to address the reader directly and never lapses into a confessional mode. The sudden upsurge of interest in private and individual concerns which became apparent in many West German novels of the period hardly came as a surprise to the 'Grazer' and other Austrian authors as they had not been caught up in the 'Politisierungsprozeß'. The existential dimension had been present from the outset in 'Grazer Literatur'. The problem in Austria had centered more on the question of form and by the early 1970s the first wave of the Graz Group had already conducted a number of fruitful formal experiments which now allowed them to adopt a more detached and disciplined approach to the expression of themes central to the individual's experience of the life-world.

As a character Haid is substantial. He is equipped with a detailed biography and has friends, interests, and problems to which contemporary readers can relate. Not surprisingly, certain, but by no means all details have some correspondence with Roth's own life. The most sustained autobiographical connection is the introduction of the story of the grandfather who tried unsuccessfully to reach America as a stowaway (p. 18, pp. 203-204, p. 221). (Roth employs this same story, based on the life of his own grandfather, as a leitmotif in the later novel Winterreise). Some reviewers like Klaus Völker tended to exaggerate the autobiographical element, which Roth found annoying as he had worked hard to limit it. ${ }^{175}$ Throughout the novel Haid remains convincingly vulnerable, questioning, fallible, and sympathetic, whether he is viewing the world 'poetically' or acting in a 'hypochondriacal' manner. $\mathrm{He}$ is neither heroic, nor self-consciously anti-heroic. To some extent, as the deceived husband, he corresponds to the traditional type of the cuckold, a very human and slightly ridiculous figure, especially in his own eyes. His feelings of guilt, anxiety, and sense of shame help to make his character accessible to a wide readership. In naming his central character, Roth consciously echoed the darker of the two personalities embodied in R. L. Stevenson's famous Dr. Jekyll. In the original story, Hyde plays the role of the 'evil that is present' to Jekyll's 'would do good'. Through Haid's repressed hostility towards his wife, Roth also explores some of the darker aspects of the mind, including his lingering suspicion that the capacity to commit murder runs closer to the surface than many would care to admit. This is a theme which Handke

\footnotetext{
${ }^{174}$ See Der Spiegel, No. 31, 26 July 1976, p. 125.

${ }^{175} \mathrm{~K}$. V., 'Auf der Suche nach sich selbst', Völker rebukes Roth for an unsubstantiated 'autobiographische Fixierung'. See Note 165.
} 
examines in Der kurze Brief zum langen Abschied and later in Die Stunde der wahren Empfindung, and Der Chinese des Schmerzes. Haid is a very appropriate name for a character whose consciousness is so divided and whose motivations are often ambiguous. Haid's melancholy and despair are, however, relieved by the comical nature of some of his adventures.

In contrast to Roth's previous creations, Haid's character shows genuine development. True to the type of the 'Entwicklungsroman', the novel portrays Haid's attempts to come to terms with his situation and to reorientate himself in the hope of growing beyond his habitual negative responses. Haid moves from a debilitating state of anxiety verging on paranoia towards a sense of peace and a new openness which includes the possibility of love for others. His gradual progress towards this end is brought about primarily by his efforts to be honest about his feelings and reactions. Roth himself felt that there should be a vital connection between the impulse to write and the desire to be honest 'Schreiben und ehrlich sein ist das gleiche': 'Wenn man etwas erzählt, wird man eine Erzählfigur. Man nimmt eine Position ein. Das Schwierige ist dann, $\mathrm{da} \beta$ aus der Position keine Pose wird'. ${ }^{176}$ Confronted by people who make him feel insecure, Haid struggles to maintain his integrity: 'Wenn ihm nichts einfiel, wollte er schweigen' (p. 46). Watching the sun set on the horizon in Los Angeles, Haid feels an undefined longing: 'Was war er? Klein, wehrlos, geschwätzig und mit seinem Ich unrettbar verbunden. Sein Ich hing an ihm wie eine Klette. Es veranlaßte ihn zu Lügen, zu Grimassen, zur Verstellung. Es verlangte stets eine Bestätigung und trieb ihn dazu, so aufzutreten, als sei er im Recht' (pp. 98-99). He becomes aware of how narrow his outlook has become as a result and that he can live differently: 'Und jetzt, als er zwischen den beleuchteten Reklametafeln und unter dem tiefgrünen Himmel dahinfuhr, spürte er zum ersten Mal, wieviel Platz in ihm war, um das Leben in sich aufzunehmen' (p. 99). He tries harder to be himself: 'Er nahm sich vor, das auszusprechen, was er dachte. Er würde nur noch das tun, was er für richtig hielt' (p. 128).

Roth rejects as insincere the 'cult of intimacy' which tended to characterise human relations in the wake of the sexual revolution of the 1960s. Unlike Donald Barthelme and other American creators of the 'New Fiction' of the 1970 s, Roth does not use this as a pretext for a retreat into a posture of cynical detachment: 'Er wußte, daß er zynisch würde sein können, aber er würde keine Genugtuung darüber empfinden, zynisch zu sein, und er wollte auch nicht mit Zynismus auf seine Unsicherheit reagieren' (p. 215). Guilt, shame, and the pain of emotional loss are not trivialised but are taken as fit cause for reflection. In his encounter with Christine, an Austrian woman whom he knew at university who is now married to an American bank official, Haid feels a strong sense of

${ }^{176}$ Anon., 'Schriftsteller Gerhard Roth: Die Kraft des Schreibens', Profil (Vienna) No. 42, 30 October 1974, pp. 35, 38, 39 (p. 35). 
disquiet at the thought that he might be falling in love with her. It is not that he cannot accept the possibility of loving another but that he is wary of his own tendency to act out a stereotyped romantic role in order to protect his real emotional vulnerablity. There is a distinct element of narcissism in Haid's psychological make-up which causes him to feel threatened by the prospect of loving and of being loved. The risk of letting go, becoming vulnerable again, and then possibly being humiliated leads him to hold his emotions in check: 'Die Angst in jemandes Augen dumm zu wirken schien ihn immer beherrscht zu haben' (p. 128). He notices how this fear affects the behaviour of others as well, causing them to behave falsely. At the same time, Haid is becoming sufficiently self-aware not to be able to avoid his true feelings: 'Er drehte sich zu Christine hin, die automatisch einen stumpfsinnigen Gesichtsausdruck angenommen hatte. Aber es war etwas in ihrem Gesicht, das er liebte' (p. 145). Immediately he is conscious of the pain of this love and shrinks from it: 'Er spürte diesen Gedanken wie einen Schmerz. Er wollte sich nicht mehr verlieben. Es war ihm, als müßte er sich freiwillig dem Wahnsinn aussetzen. ... Er hatte die Liebe nur als Schmerz empfunden' (p. 146).

It is a sign of Haid's increasing ability to accept life as it is that he allows his feelings for Christine to show. At first she reciprocates then withdraws when she discovers that she feels somehow alone in his presence. Haid is disappointed but understands her reasons and finds himself able to let her go without being overwhelmed by a sense of loss. He moves into a hotel where he is taken ill with a throat infection. He experiences the illness as a release, as he had often done as a child: 'sie hatte ihn seiner Verpflichtungen und Sorgen enthoben und in einen Leerraum versetzt, der frei war von Ängsten und Hoffnungen' (p. 176). In the very last scene of the novel, Haid watches the small, thin figure of a boy playing in Washington Square. Something about the boy reminds him of his grandfather whom he loved and he looks at the boy as if he were seeing his grandfather as a child. The boy runs off through the park. The novel ends with an affirmation of life. Haid feels that he has dreamed a long dream to its end. Suddenly he experiences a strong feeling of love which, in the context of his development, can only be interpreted as a moment of genuine and unselfish empathy with the life around him. His fears and insecurities drop away: 'Er erhob sich und empfand plötzlich ein so starkes Gefühl von Liebe, daß er glaubte, es könne ihm nie mehr etwas geschehen' (p. 221). There are parallel moments in a number of Handke's novels but the clear, detached, and thoroughly unsentimental prose of Horizont makes Haid's brief, unexpected apprehension of a love appropriate to his earlier intimation of an 'andere Form der Wirklichkeit' somehow more convincing.

Der große Horizont communicates a strong sense of reality. It is important, however, to realise that the convincing nature of the characters and of the American setting is not the product of a conventional narrative realism. Roth's 
'neurotische Wahrheitsliebe', his insistence on unusually precise detail, is certainly indicative of a strong mimetic impulse. But the continuity with his earlier works is such that the accumulation of realistically observed detail serves to undercut and render ambiguous the impression that the novel deals with real people from the real world. The relationship of the novel to realism is further complicated by the inclusion of some figures taken from real life. Haid's friend Mehring has a counterpart in a professor of literature in California. There is a reference to Hacker, a researcher in the psychology of aggression (p. 111), a scene at the house of the American poet, Michael McClure (pp. 55-57), and mention of Gertrud Frank, an editor for Salzburg's Residenz Verlag, who died in 1974. Even Carson borrows her name from the American author, Carson McCullers. But like Haid's real-life observations, these historical incursions ultimately call the everyday reality of Horizont into question.

Shortly after his arrival in America, Haid notices how much he tends to lose himself in the unrelated details which attract his attention: 'wie sehr er sich in Einzelheiten verlor' (p. 11). He notes further that as a mere tourist in America with no love or personal connection to what he sees, the totality of the images in which Marlowe sometimes discovers 'poetic' moments produces only a feeling of emptiness: 'Er dachte wie sinnlos all diese Bilder waren, die er sah. Es war auch sinnlos, daß er hier ging. Nein, Gott verbarg sich nicht in jedem Atom des Feuerschlaucheinsatzes aus Messing, der Plastikjacke des Negers, verbarg sich nicht in all den Zwecken und technischen Regelmechanismen, in all den leeren Gesichtern. Haid stellte sich neben den Neger vor die Auslagenscheibe und betrachtete sein eigenes Gesicht. Es war ebenso leer wie das aller anderen' (p. 42). Images of life as a dream, as a film, and therefore as a fiction recur in the novel, for example: 'Wie immer, wenn er getrunken hatte, verwandelte sich die Wirklichkeit in eine Art Farbfilm' (pp. 29-30); 'Haid war nicht in einen Traum gefallen, sondern der Traum wurde ihm mit realen Mitteln vorgespielt' (pp. 35-36) and 'Ihm kam im Augenblick alles vor wie eine Filmvorschau, er sah einzelne bewegte Bilder, die ohne Zusammenhang waren, den er sich erst im Kopf zusammendichten mußte' (pp. 46-47). In addition to his Walter-Mitty-like daydreams about being Marlowe, there are references to specific films and actors which Haid draws into his fantasies: the chase sequence from the Steve McQueen thriller 'Bullitt' (p. 72); a Humphrey Bogart gangster film (p. 66); O'Maley as Victor Mature in a B-grade shoot-out fantasy (p. 150); a New York scene from the film 'French Connection' (p. 198).

References in the novel to other writers, philosophers, and their ideas also reinforce the view that the realism of Horizont is only apparent, a matter of approximation to a realist style, and certainly not based on the belief that there exists a commonly shared reality which language can effectively capture. 
While suffering 'ein Gefühl der Schwerelosigkeit' in a bar in San Francisco's Chinatown, Haid is offered a strange drink by Hermann Hesse who asks him: 'Haben Sie noch ein Zeitgefuihl?' (p. 34). He then notices that he is sitting next to an old Chinese man. The suggestion here of illusion and multiple levels of reality links this scene to the 'magisches Theater' of Der Steppenwolf. In a park Haid thinks about Alice in Wonderland and half expects to see a white hare run across the grass and up a tree (p. 75). There are references to Stifter and Der Nachsommer. In one, Haid talks to Mehring of the Utopian dimension in Der Nachsommer and says that for him, Stifter is a science-fiction author. In another, he alludes to Stifter's notion that the poetic is the presupposition on which all realism must be founded. Again this is quite a different form of realism to that of naturalism and its successors and must be seen in the context of Roth's interest in Stifter's linking of science and aesthetics. ${ }^{177}$ On a visit to his friend Kapra in Santa Monica, Haid notices that Kapra is reading $A$ Separate Reality, a popular counter-cultural work of the early 1970s, one of a series of books on sorcery amongst Mexico's Yacqui Indians by the U.C.L.A. anthropologist, Carlos Castaneda (p. 87). Kapra later explains to Haid some of the teachings of the sorcerer, Don Juan (p. 100). Haid reflects on the idea that there may be levels of his experience of which he is not aware but which may be accessible to others. The thought that Kapra might make use of hidden powers to connect him to Carson's death makes him uncomfortable.

Haid's meeting in San Francisco with the poet McClure whom he visits with his friend Mehring, introduces an interesting reflection on the relationship between a reportage-like realism and fiction. The figure of McClure is a representation of the real-life American poet, Michael McClure, who lives in San Francisco. As a figure who has been appropriated from another level of reality - Roth met him while visiting the U.S.A. - McClure lends a curious sense of authenticity to the scene which Roth portrays exactly as he experienced it (Interview 1). Roth uses McClure's ideas as a foil to Haid's thoughts on a more direct perception of things. McClure's poetry as it is represented, for example, in the collection Jaguar Skies, expresses a fusion of poetry and metaphysics, a way of looking at the universe in which man's innate 'biological intelligence' is reawakened. Like Castaneda, he also asserts that there are multiple levels of consciousness in an intelligent universe. Haid listens carefully to what the poet's fictionalised counterpart has to say:

McClure schien durch die Natur zu wandeln, wie ein Astralleib. Jedes Tier, jede Pflanze umfing ihn mit einer magnetischen Strahlung, die ihn berauschte ... Haid ließ sich selbst dazu hinreißen, alles in derselben Weise zu sehen und $\mathrm{zu}$ verstehen wie McClure und darum war ihm, als begegnete er sich

${ }^{177}$ See comments on Roth's essay, 'Technik des Naturempfindens gegen Kunst der Technik', p. 85 above. 
selbst. Die magische Versenkung in die Natur schien ihm notwendig ...' (p. 57).

Haid wonders if the best way of viewing the world might not lie in a synthesis of McClure's 'biological intelligence' and a revolutionary critique of social and political institutions to produce a consciousness which would observe the development of society with the same sensibility as a work of art or nature itself. McClure's ideas have a calming effect on the anxious Haid. Later he looks up at the stars and thinks about what McClure has said: 'Die Sterne machten ihn friedlich und klein, und seine Einsamkeit störte ihn nicht mehr' (p. 58).

Roth's treatment of the historical McClure in the novel has a parallel in Handke's treatment of the American film director, John Ford, in Der kurze Brief zum langen Abschied. At the close of that novel, the narrator and his estranged wife, Judith, sit talking to Ford about their American adventure. The scene conveys a dream-like mood of peace and reconciliation. The difference is that Handke's 'Ford' is a careful fabrication out of Handke's knowledge of Ford and his films. Ford was still alive at the time the novel was written and the reader might be forgiven for thinking that Handke is drawing on actual experience. But the mimetic effect of the scene is the product of a montage-like process, a clever forgery which only seems to be real. Further literary references in Horizont from well outside the realist mode include Haid's encountering of W. B. Yeats's metaphysical treatise, A Vision (p. 106), the mention of Longfellow's romantic novel Hyperion (p. 111), and two quotations from Kierkegaard, one concerning the way the world appears to serve only as a trigger for memories (p. 165) and the other describing the world as the 'medium' in which we live (p. 174).

The link to the minor but significant strand of social and cultural criticism which runs through the novel is provided by a number of references to Horkheimer's views on modern, technologically advanced society. Although everything in Horizont is presented subjectively through the filter of Haid's shifting moods and emotions, there is also no doubt that the glimpses of American society which recur throughout the novel are firmly grounded in Roth's observations of and reflections on the America he actually experienced in 1973, as opposed to an imagined or idealised version of that country. Horizont is the first work in which Roth begins to confront social and political issues. Questioned about the political dimension in his novels, Roth described his two 'American' novels as both containing 'bewußt Passagen mit gesellschaftspolitischen Auseinandersetzungen. Das Amerikabild, das ich meine Figuren erfahren lasse - und das auch mir so erschien, wie ich es erlebt habe kann man ganz sicherlich als gesellschaftspolitisches Ergebnis bezeichnen, wenngleich mir jedesmal nur diese Dimension zu wenig wäre' (Interview 1). 
The references to Horkheimer occur in the context of Haid's reactions to specifically American social conditions and patterns of behaviour which he observes and tries to interpret: 'Bei Horkheimer sind Auseinandersetzungen mit der Armut in Amerika, mit der Frage nach der Gewalt usw. Es ist sehr subtil verstreut in den Texten' (Interview 1).

Horkheimer is first mentioned in the novel as Haid strolls through a large department store in San Francisco (pp. 31-32). He sees the shoppers buying goods as if they are under a compulsion to consume. He is reminded of Horkheimer's notion that having eliminated any traces of 'Geist', people would one day live in a state of total contentment, fully reconciled to the demands of consumption and production. Watching the people around him, Haid feels that he is glimpsing something of this unreflective, dehumanised future. Haid is aware that there is no essential difference between what he observes here and what occurs in Vienna or Berlin, but feels that American goods exude a stronger aura of prestige as if acquisitiveness were more systematically cultivated in the U.S.A. to become an irresistable desire to possess. Haid then sees in his mind Horkheimer standing before him 'mit glatzköpfigem Eierschädel, die dicke Hornbrille im Gesicht, leicht gebückt, eine Mischung aus einem lächerlichen und einem großartigen Menschen' (p. 32). Haid thinks of those for whom everything in life is reduced to what serves their material self-interest: 'Der Geist war nur noch eine klappernde Rechenmaschine' (p. 32). He suddenly understands and loves those young Americans who have devoted their lives to opposing this reductive materialism: 'die Amerikaner, die als buddhistische Wandermönche verkleidet Flugblätter anboten’ (p. 32).

Leaving Los Angeles Haid becomes aware of an oppressive sense of desolation in himself and the objects of the suburban landscape. This 'Verlassenheit' causes him to feel 'Ekel und Scham': 'Es ekelt ihn plötzlich davor, all das wahrzunehmen: Die silbrigen Aluminiumbehälter, die für den Abfall die Straße entlang aufgestellt waren, die grüne Landschaft des Golfplatzes mit sinnlos im Wind flatternden bunten Fähnchen, den Mann mit dem Wasserschlauch, der hinter einem niedrigen, weißen Holzzaun sein Gemüse besprengte ... das alles zu sehen ekelte ihn mit einem Male so sehr, daß er eine Zeitung vom Boden aufhob und nur die schwarzen Buchstaben anstarrte, als könne er an ihnen Halt finden' (pp. 115-116). He remembers that Horkheimer speaks of the 'unabänderlichen Verlassenheit und von der Endgültigkeit dieser Verlassenheit' (p. 115). He connects his feeling of revulsion and shame over the perception of this desolateness to Horkheimer's criticism of the 'blöden Optimismus der Gesellschaft, die ihr eigenes Wissen zu einer neuen Religion aufspreizte' (p. 116). Later, in New York, driving through a run-down part of Brooklyn, Haid again experiences desolation and melancholy. He thinks of Horkheimer's phrase 'DIE NICHTIGKEIT DES EINZELNEN' (p. 135). But he does not uncritically accept all of Horkheimer's ideas on the fate of the 
subject in an advanced technological society. Haid finds a certain arrogance in Horkheimer's assertion 'Das Thema der Zeit ist Selbsterhaltung ... während es gar kein Selbst zu erhalten gäbe' (p. 154). He argues instead that the mere consciousness of one's own mortality is justification enough to speak of a self and cites Tolstoy's view that humankind experiences a little of its own extinction in every pain or illness. Haid's melancholy in New York also leads him to reflect on Horkheimer's notion of 'SEHNSUCHT NACH DEM GANZ ANDEREN' (p. 172) which is in part a longing for a perception of reality free of the clutter of meanings predetermined by interested power brokers. Haid associates this with the idea that the goodness attained by an individual in an otherwise powerless and wretched existence might not be altogether lost but might eventually participate in 'einen ewigen Morgen' as suggested by Horkheimer. Haid is not vain enough to see his own life in this light but nonetheless accepts as a kind of 'Prinzip Hoffnung' the idea that something resembling this 'everlasting morning' might possibly exist. Underlying Haid's reactions to the many instances of poverty and neglect he encounters in America is the conclusion reached by Horkheimer and Adorno in Dialektik der Aufklärung that in America no distinction is made between man and his economic fate. Although he discovers a certain pleasure in the anarchic poetry he perceives at times in the urban American landscape - 'Es war gewiß diese Form der Poesie, die in Chandler's Kopf Philipp Marlowe erzeugt hatte' (p. 188) - Haid's conscience is troubled by the realisation that so much human suffering results from the nation's single-minded pursuit of material wealth. In spite of the fact that he is often well treated by those he encounters and there are moments when he sees America in a positive light, Haid rejects the idea of America as a Utopia. He cannot accept American society and culture as a desirable model for his own or anyone else's way of life:

Einmal trat ein Neger mit einem Aluminiumbecher aus einer Hausnische, streckte die Hand vor ihm aus und rief: "CASH!" Haid ging, so wie er es bei den anderen sah, weiter. Er haßte Amerika in diesem Augenblick. Eine Gesellschaft vom Reichtum und der Größe Amerikas lebte gleichgültig mit einer großen Masse von Bettlern, Trinkern, Verzweifelten, als seien diese notwendig für die Gesellschaft oder als besäße man Einsicht in einen Schöpfungsplan, nach dem all dies als etwas völlig Natürliches geschaffen worden war und das unausrottbar in aller Ewigkeit bestehen würde (p. 18).

Haid has seen such people in Vienna but here in America he is not sure which of them are genuine and which are only playing at being 'Armer, Krimineller, Asozialer oder Verriuckter' in order to be left alone. It is here that he reflects on what would have become of his grandfather had he actually reached the U.S.A. Would he have become a materially successful member of society or fallen by 
the wayside? Perhaps because like many of his generation Haid somehow expected more of America, he is surprised when he notices how frequently he expresses 'Haß gegen die Technik, gegen die Zivilisation' (p. 57).

Roth may have included in Horizont a number of references to the work of a leading member of the 'Frankfurter Schule', but the result is very different to other 'American' novels by German-speaking authors writing from a sociopolitical standpoint. In the polemical Täglicher Faschismus (1971), for example, the West German author, Reinhard Lettau, creates a negative image of the erosion of political freedom in America from a montage of newspaper extracts over a period of six months. Lettau relies heavily on a Marxist ideological framework and employs second-hand reports to provide his 'factual' evidence. In contrast, Roth introduces some of Horkheimer's ideas in a detached and reflective way, testing them against his actual observations: in keeping with the spirit of 'Grazer Literatur', they are simply fragments of one of many possible interpretations. To complain as one critic did (Klaus Völker: see Note 167 above) that the social and cultural criticism in the novel is lacking in real consistency is to mistake Roth's intentions. In Daniel Haid he portrays the approach of the educated non-specialist whose personal dilemmas permit only brief excursions into the realm of social theory. There are numerous images of America in Horizont which are the result of independent personal observation. In the course of Haid's adventures, Roth creates a complex and varied picture of America, ranging from the dark underworld of Harlem, into which Haid plunges suicidally with O'Maley, to the gilded luxury of Christine's Manhattan appartment. Finally, it must be remembered that Roth did not set out to write a novel about America. The sharply observed and often fascinating images of American life which emerge from Horizont are secondary to the charting of Haid's search for his own identity in a largely phantasmagoric American setting.

Roth's early 'Kurzromane' had alerted the West German 'Kulturbetrieb' to the emergence of another talented young 'Grazer'. The publication of Der große Horizont established Roth as an Austrian author to be taken seriously. Horizont offers a remarkable textual density for further interpretation and yet the fusion of popular and demanding elements also makes it eminently readable. The novel attracted a wide range of positive criticism with critics expressing few serious reservations about either the form or content. Reviewers repeatedly emphasised the sobriety and unpretentiousness of Roth's clear, precise prose style which alone served to distinguish the novel from many others published in 1974: 'eine Sprache, deren Einfachheit die volle sinnliche Kraft des Sagens freisetzt' (the same reviewer sees fit to compare Roth's style to the ideal set down by Hofmannsthal in 1907 - 'Es ist als hätten seine Augen 
keine Lider'); ${ }^{178}$ 'Er beharrt auf einer eher wissenschaftlich gestimmten Nüchternheit. Statt melancholischer Schnörkel liefert er Befunde'. ${ }^{179}$ A review of Horizont written for Merkur by Heinrich Vormweg is perhaps the most astute in detecting the literary-historical position of this novel. Vormweg begins by distinguishing two approaches operating within the shift towards realism evident even amongst experimentally inclined authors at the time: an autobiographical orientation characterised by 'persönliche Selbstfindung und Auseinandersetzung mit der wachsenden Spannung zwischen Selbst und Umwelt', and a style which is markedly objective 'mit Hauptfiguren, die nicht mehr deutlich erkennbar Projektionen des Autor-Ichs sind, sondern analog den ungezählten Helden der literarischen Tradition zwecks Verdeutlichung allgemeiner Vorgänge und Zustände in die Lesewelt geschickt werden' ${ }^{180}$ To this second category Vormweg allocates Horizont but qualifies this with the approving observation that Roth's 'stets am Konkreten orientierten Sprache' also demonstrates the futility of the attempt to grasp reality by means of narrative realism - 'Der große Horizont ist zum Bersten angefüllt mit Fakten, Ansichten, Körpern, Empfindungen. Und zugleich ist er völlig leer' ${ }^{181}$

As an example of 'Grazer Literatur', Horizont represents the polar opposite of the narrow, introverted, psychologically and politically crippled literature of the Austrian provincial hinterland which the Graz authors set out to overcome. In it a young Austrian driven by the very human emotional pain stemming from the breakdown of his marriage sets out to find himself not in Austria but in an America which represents in its most advanced form the modern labyrinthine world. The horizon of Haid's search for meaning and identity could not be broader or more open. The alienation he experiences there has very little to do with the fact that he is an Austrian, a European, in what W. H. Auden called the 'Great Wrong Place' of the modern urban world. ${ }^{182}$ Haid's problem is universal. When an excited, mentally disturbed black Haid encounters in San Francisco misunderstands him and thinks he is from Australia, he reflects on the irrelevance of his Austrian background to his present circumstances: 'Haid war das egal. Wovon hätte er erzählen sollen, in dieser verdreckten Imbißstube, von Mozart, Beethoven, Stifter, vom AUSTRO-MARXISMUS oder von Lipizzanern' (p. 20). The central theme of the novel - the

\footnotetext{
${ }^{178}$ Dominik Jost, 'Zwischen Hofmannsthal und Handke: "Der große Horizont" von Gerhard Roth', Neue Zürcher Zeitung, 12 December 1974.

${ }^{179}$ Günter Blöcker, 'Die ganze gewalttätige Widersprüchlichkeit des Schlachtfeldes New York: Gerhard Roths vierter Roman "Der große Horizont"', Frankfurter Allgemeine Zeitung, 26 November 1974.

${ }^{180}$ H. V., 'Ein Detektiv seiner selbst', Merkur, 322 (1975), pp. 283-285 (p. 283).

${ }^{181}$ ibid, p. 285.

${ }^{182}$ W. H. Auden, 'The Guilty Vicarage', in The Dyer's Hand and other Essays, (New York, 1956), p. 151.
} 
falling apart of self and world - is, however, at the heart of Austrian literary tradition. At the end of Horizont the reader is left with the impression that the complexity of human experience has been heightened, not fictionally reduced and that, without resort to mystification, Haid has been restored to a feeling of respect for life and the mystery of his own being.

\subsubsection{Ein neuer Morgen}

Roth's second 'American' novel, Ein neuer Morgen, was published by Suhrkamp in the Spring of 1976. Roth drew on unused material from his first American visit in 1972 as well as new notes, photographs and ideas gathered on his second trip to the United States with Wolfgang Bauer in March of 1973. In 1974 growing recognition of his work had led to the award of the 'Literaturförderungspreis der Stadt Graz' in the prize's inaugural year, an honour he shared with Kolleritsch and two other local writers. In October 1975, while working on the novel, Roth was awarded the 'Literaturpreis des Landes Steiermark' which was worth 30,000 Austrian Schillings. This was not a large sum, but together with advances made on the basis of a firm contract with Suhrkamp, he was at last able to consider taking twelve months leave from his position at the Graz computer centre to write full-time. Towards the end of 1975, he separated from his wife and children, at first on a trial basis and later permanently. He rented an apartment on the floor below his mother's in a block built in the 1930s on the Geidorfgurtel near the university. Except for a bed and a table, the apartment was bare and in his first few months living there alone he endured a period of personal crisis. The difficulties he experienced during this time are reflected in his second drama Sehnsucht (See Note 224), on which he worked after completing Ein neuer Morgen.

Ein neuer Morgen is an accomplished narrative which represents the logical continuation from Der große Horizont of Roth's line of enquiry into the problematic nature of the longing for an authentic sense of identity in the increasingly mediatised, post-industrial life-world experienced by his generation while continuing to explore his own orientation as a writer and social being. The novel met with a sound measure of positive reception from established literary critics. Heinz Ludwig Arnold clearly grasped the relationship of this book to its predecessor - 'Ein neuer Morgen nun verhält sich zum Großen Horizont wie ein Außenbild zum Innenbild' - and concluded that Roth had succeeded in writing 'einen spannenden, oft in der Schwebe gehaltenen Roman'. Ulrich Greiner claimed that it showed 'Gerhard Roth in der logischen Fortsetzung seines bisherigen Wegs, denn hier ist es ihm gelungen, ein in Wahrheit dunkles Thema fast schwerlos darzustellen. ... Kein Zweifel, daß er neben Thomas Bernhard und Peter Handke zu den bedeutendsten österreichischen Gegenwartsautoren gehört'. Lothar Baier described it as '... einer der aktuellsten, spannendsten und ästhetisch am konsequentesten gearbeiteten 
Romane, die in diesen Jahren geschrieben worden sind'. ${ }^{183}$ But the opinion of other serious commentators was less favourable and contained reservations largely concerning what they judged to be the derivative recourse of an obviously talented young writer to the fast action and suspense of crime fiction. When the novel is compared with Horizont it can be seen to lack the rich narrative texture and some of the psychological complexity he had achieved there but a careful examination of its narrative construction reveals that Roth achieved much more than what those reviewers who tended to overlook the way he subverts the typical characterisation and plot trajectory of the crime novel, dismissed as a typical example of intellectual crime fiction or, somewhat more subtly like Beatrice von Matt, as the product of a flawed union between the thematic interests of the 'Entwicklungsroman' and the plot mechanics of the detective genre. The harshest criticism is directed at the novel by Jörg Drews who previously found much to admire in Roth's work: he now finds the figures and the story 'fischblütig', Roth's simple manner of narration 'leer und zugleich gestelzt', and dismisses Morgen as 'eine dürftige Geschichte rund um ein Photoalbum aus Amerika, welchem Land Roth mit einer modischen Schwäche und mit einem Hang fürs Mondän-Weltläufige zugetan scheint'. ${ }^{184}$

Friedrich Weininger - in the context of Austrian cultural history the protagonist's surname inevitably evokes the memory of Otto Weininger's celebrated turn-of-the-century identity crisis par excellence - is a thirty-threeyear-old Austrian photographer who is in New York on an assignment for a German publisher. He has been in the city for several weeks and, like Wim Wenders' German journalist-photographer, Philip Winter, on assignment in the U.S.A. in the film Alice in den Städten (1974), Weininger is having difficulty finding the American images he needs for the book. He makes acquaintance with an American named Norman Dalton. Dalton's previous existence as the bank executive, Robert Finn, remains concealed from Weininger until much

${ }^{183}$ Ein neuer Morgen was positively received by Heinz Ludwig Arnold, Ulrich Greiner, Jürgen P. Wallmann and Lothar Baier i.a.: Heinz Ludwig Arnold, 'Der Detektiv Olson und die Zwillinge. Gerhard Roths 'autonome Prosa', Deutsches Allgemeines Sonntagsblatt, 21 March 1976; Ulrich Greiner, 'Ein Mord, eine Verfolgungsjagd und die unstillbare Sehnsucht jemand anderer zu sein', Frankfurter Allgemeine Zeitung, 30 March 1976; Jürgen P. Wallmann, 'Dalton taucht unter: Gerhard Roths scharf belichtetes New-York-Bild', Deutsche Zeitung, 3 April 1976; Lothar Baier, 'Gerhard Roth: Ein neuer Morgen', WDR, III. Programm, Kulturelles Wort, broadcast 20. April 1976 (transcript).

${ }^{184}$ The novel disappointed the expectations of Jörg Drews, Joachim Kaiser and Beatrice von Matt: Jörg Drews, 'Kein neuer Morgen. Eine Geschichte rund um ein PhotoAlbum aus Amerika', Die Zeit, 9 April 1976; Joachim Kaiser, 'Krankes, blankes Kamera-Auge: Gerhard Roths Roman Ein neuer Morgen', Süddeutsche Zeitung, 2627 May 1976; Beatrice von Matt, 'Talent und Routine: Gerhard Roth und sein neuer Roman Der [sic] neuer Morgen', Neue Zürcher Zeitung, 31 May 1976. 
later. From the outset he is intrigued by Dalton's cool and apparently indifferent manner. Weininger rapidly becomes involved with Dalton's girlfriend, Patricia, who works for a Manhattan antique dealer. The narrative is divided into two sections. The first section, Weininger, in which Roth builds up suspense around the mystery of Dalton, occupies most of the book. It is only in the final twenty-four pages in the second part, Dalton, that Weininger and the reader learn the truth about Robert Finn, the man Weininger first strikes up a casual acquaintance with in a New York bar.

The framework of the story Roth tells in Ein neuer Morgen is foreshadowed in Wille as the subject of a film which Kalb happens to see in a non-stop cinema: 'Der Film handelte von einem Fotografen, der überraschenderweise in einen Mordfall verstrickt wurde' (Wille p. 149). Roth may very well have worked here from a recollection of Michelangelo Antonioni's film Blow-Up (1966) which explores photography's complex mediation of perception and the textual construction of 'reality'. As Ulrich Greiner observed, there is a distinct parallel between the organising perspective of the film and Roth's novel: 'Ganz ähnlich wie der Fotograf ... nimmt auch Weininger die Welt nur durch den Sucher seiner Kamera wahr' ${ }^{185}$ In this context the film referred to in Wille functions as a kind of literary trailer to the novel. In terms of the interrelated themes in Roth's work and their continuity, it is interesting to compare the passage from Wille cited above with the following passage from Morgen:

Er ging langsam die Fifth Avenue hinunter, wechselte zum Broadway und betrachtete die Trailers unter den gläsernen Kinovordächern, die über einen Bildschirm Nonstop abgespielt wurden. Er sah sich gerne Trailers an, weil sie ihm vorkamen wie Situationen, in denen Ereignisse der Zukunft eine große Rolle spielen ... Dalton oder der Fremde oder Patricia, sie waren wie die Figuren von Filmauschnitten: ohne Ursache und Zusammenhang waren sie in sein Leben getreten und jeder hatte seine Geschichte, in die verwickelt zu werden, es ihn plötzlich reizte (p. 31).

Weininger's chance involvement in the criminal affair surrounding Dalton begins on a visit he makes with him to the New York Stock Exchange. Weininger notices a man following Dalton from a distance and later finds the same man dead in Dalton's apartment. Dalton disappears and ensuing events draw Weininger and Patricia closer together. He realises that she is also being watched and assumes the role of her protector. Eventually Dalton makes contact with Patricia by phone and arranges a meeting which culminates in a shoot-out on a crowded New York street. Dalton escapes unharmed, leaving Patricia with an envelope containing an air-ticket to Europe and a hotel

${ }^{185}$ Ulrich Greiner, 'Ein Mord, eine Verfolgungsjagd und die unstillbare Sehnsucht jemand anderer zu sein'. 
reservation. Weininger accompanies Patricia to Nice, where Dalton is waiting for her. Dalton listens to their story then tells them his.

Roth's interest in the Chandlerian 'Kriminalroman' as a source of structural devices and thematic ideas that he could adapt as solutions to the problems he faced developing longer fictional narratives, informs Morgen to an even greater extent than Horizont. Again he is not merely imitating the conventions of the detective genre but actively adapting and transforming its typical narrative elements to tell a very different kind of story, an exploration of the narrative politics of the identity quest depicted in the intertwining stories of Weininger and Dalton. In an interview he commented on the way his reading of Chandler helped him to structure Morgen:

Ich habe eigentlich schon die Absicht gehabt, einen Kriminalroman $\mathrm{zu}$ schreiben. Ich bin ein großer Bewunderer von Raymond Chandler und fasziniert hat mich an Kriminalromanen einfach die Möglichkeit, mit Hilfe von Spannung einen Leser bis zum Schluß sozusagen an der Stange zu halten. Ich habe diese Methode verwendet, um die Geschichte des Norman Dalton bis zum Schluß aufschreiben zu können und dann ganz konzentriert die Lösung eines Problems und die Lösung der Geschichte zu schildern. ${ }^{186}$

Whereas in Horizont the references to Chandler and Marlowe had been made explicit in instances of Haid's 'Chandler Krankheit' ${ }^{187}$ and had provided Roth with a model to reflect playfully on the dynamic interaction between authorial self, material and protagonist, in Morgen the meta-narration of the authorreality-fiction relationship is collapsed into a more direct exploration of the possibilities of the detective genre. To Roth, if not to some of his critics and reviewers, Morgen represented a further step towards expanding the expressive range and the popular appeal of his narrative writing.

Two familiar elements of the urban detective novel are immediately apparent: the nature of the action - Weininger's involvement in a series of events that quickly turn into a pursuit - and the urban setting - New York City presented as an archetypal late twentieth-century criminal milieu. The connection which Roth establishes between the outward framework of the somewhat chaotic chase and the pursuit of a notion of authentic existence, which to different degrees preoccupies both Weininger and Dalton, represents Roth's attempt to adapt typical features of the genre to his own narrative purposes. The genre referencing enables Roth to express through concrete events his interest in the unstable nature of identity formation, as well as bringing to the narrative a degree of suspense and motivation for the rapid

\footnotetext{
${ }^{186}$ Sigrid Esslinger, 'Gerhard Roth: Ein neuer Morgen', Bayerischer Rundfunk (Fernsehen), broadcast 23 May 1976, transcript, p. 3.

${ }^{187}$ Ulrich Greiner, 'Ich will ein Erzähler sein: Porträt des Schriftstellers Gerhard Roth'.
} 
narrative pace with which he hoped to hold the interest of a wider reading public.

Weininger's story, into which Dalton's account of his life is parenthetically inserted, is composed in a narrative style that resembles Chandler's in its simplicity, directness, and care over descriptive detail. Roth avoids the deliberately ironic slant that characterises Chandler's first-person narrative (Marlowe's interior monologue), but preserves and increases the range of closely-observed descriptions of character, action and setting which distinguish Chandler's detective stories and contribute much towards their particular brand of psychological and social realism. Roth published in journalistic form some of the material gathered on his trips to the U.S.A. A recollection of one of his New York experiences published as 'Night Court', ${ }^{188}$ is paralleled in the novel when he portrays virtually the same scene in an expanded form (pp. 35-42). The style, a subjective, reportage-like description of events, is common to both the newspaper article and the novel. The mode of writing adopted by Roth here is that which Roland Barthes identifies as 'neutral' or 'colourless' 189 and is characterised by terse, declaratory sentences conveying a strong sense of emotional detachment while describing without compromise the events which come to Weininger's attention. During the time he was working on Morgen, Roth pinned a card above his writing desk on which he had written in large letters the admonition 'Einfach!'. ${ }^{190}$

Weininger's association with Dalton leads him rapidly into situations the atmosphere and action of which are reminiscent of Chandler's novels. On his first visit to Dalton's rented room, he is shown a Smith and Wesson revolver which proves to be an omen of events to come. Dalton explains that he has purchased a gun from someone connected with the F.B.I.: 'Sie ist das einzige Möbelstück, das mir gehört' (p. 15). Dalton's ironic remark is typical of the dialogue of the many psychologically flawed and ultimately desperate figures in Chandler's narratives and even of Marlowe himself. The reproduction of such instances of laconic speech also reflects the enthusiastic reception by Roth's generation of popular post-war American cinema, especially of American films noir, included among the better known of which are a number of renderings of Chandler's novels and filmscripts, and their reading of other examples of 'tough' detective fiction by writers like Dashiel Hammett. In a

${ }^{188}$ 'Night Court', Neue Kronenzeitung (Steiermark-Ausgabe) (Graz), 29 September 1974. Others published in the Neue Kronenzeitung include 'New York I', 30 March 1974, and 'New York II', 6 April 1974. 'Night Court' is reprinted in MBM, pp. 6163.

${ }^{189}$ Roland Barthes, Writing Degree Zero, translated by Annette Lavers and Colin Smith, (London, 1967), p. 11.

${ }^{190}$ Ulrich Greiner, 'Ich will ein Erzähler sein: Porträt des Schriftstellers Gerhard Roth': '... er berichtet, wie er sich, als er den "Neuen Morgen" schrieb, über seinen Schreibtisch ein Schild geheftet habe, auf dem in großen Buchstaben das Wort "Einfach!" stand". 
manner exemplary of the mesmerising effects of stylised examples of American popular culture, Weininger at first fails to grasp the extremity of Dalton's plight and is fascinated instead by what he takes to be the extraordinary indifference Dalton appears to conceal beneath an air of studied politeness. Weininger's immense curiousity about Dalton draws him into districts of New York City which in classic American detective fiction and films noir are associated with the low end of the criminal underworld - Harlem and the Bowery. In Dalton's room in the Bowery he discovers the grisly corpse of one of the Knight twins and it is in Harlem that he becomes involved in a car-chase with Olson (pp. 102-103). But what distinguishes Roth's echoing of events and settings commonly found in American detective fiction from standard examples of the genre, and even from Chandler's literary detective novels, is its filtering through the visually intense consciousness of his witness, Weininger.

The latent concern in Chandler's detective fiction with glimpses of reality as such is an element of Chandler's style which Roth expands on in Morgen. Chandler's Marlowe is essentially an outsider figure. Chandler began the 'poeticising' of the detective genre by restructuring its clichéed formulations, sometimes in a highly ironical manner. Marlowe enjoys looking at things for their own sake. The following short passages from The Long Goodbye $e^{191}$ are indicative of this lateral, poetic aspect of Chandler's style and reveal the semantic range, colour and ironic tone of these descriptive excursions:

The coffee-maker was almost ready to bubble. I turned the flame low and watched the water rise. It hung a little at the bottom of the glass-tube. ... Very methodical guy, Marlowe. Nothing must interfere with his coffee technique. Not even a gun in the hand of a desperate character (p. 25).

San Diego? One of the most beautiful harbours in the world and nothing in it but navy and a few fishing boats. ... The swell is as gentle as an old lady singing hymns. But Marlowe has to get home and count the spoons (p. 33).

Chandler's approach to the evocation of such detail not only increased the sense of everyday realism but also served to heighten dramatic tension: the telling details are concealed among those which are incidental.

In Horizont, Haid expressed interest in the mixture of poetry and anarchy he found in Chandler's work. In the following passage from that novel we find clues as to what it is that now attracts Weininger to many of the scenes he is drawn to photograph in New York, especially in Harlem and the Bowery:

Haid spürte, wie ihn der Anblick der Straße immer mehr gefangen nahm, wie er für ihn poetisch geworden war, und er fragte sich, ob diese Form der

${ }^{191}$ Raymond Chandler, The Long Goodbye, (Harmondsworth, 1959). 
Poesie nicht mit Anarchie verbunden war, so wie Chicago mit etwas Poetischem verbunden war, das seine Wurzeln im Verbrechen hatte. Es war gewiß diese Form der Poesie, die in Chandler's Kopf Philipp Marlowe erzeugt hatte (p. 188).

Haid's anarchic embodiment of aspects of Marlowe's world-view appears again in Weininger in a sublimated form. At the time Morgen was published, Weininger was Roth's most 'normal' protagonist and, in contrast to einstein or Haid, his comparative normalcy and emotional flatness make him a less immediately appealing figure than his predecessors. In his planning of the novel around the idea of the inertia of the divided or schizoid self which emerges in response to the pressures of a conformist society, Roth consciously developed the idea of the somewhat parasitic relationship of the artist-intellectual Weininger, whose ability to act is impeded by his capacity to endlessly observe, to the decisive and ruthless executive Dalton, whose sense of being reduced to a mere drone of family and capital drives him to an extreme form of rebellion. For Roth, 'Dalton ist die Sehnsucht und Weininger die Wirklichkeit'. ${ }^{192}$

Following Chandler's lead, Roth dispenses with the plot mechanics of bringing a criminal to justice and concentrates instead on probing the everyday sense of reality. In Morgen, Dalton represents to Weininger yet another form of the anarchic-poetic tendency Haid had expressed through his identification with Marlowe. It is through Weininger's association with Dalton that his interest in photographing the often wildly colourful and aesthetically charged chaos of New York emerges:

In seiner Vorstellung sah er eine unscharfe Verbindung zwischen seinem Buch und Dalton ... Er bemerkte, daß er seit dem Morgen die Bilder, die er sah, in Gedanken ausprobierte, ob sie in das Buch paßten. Zum Beispiel den Neger mit der Wollmütze, dem roten Plastikrucksack und dem Spazierstock, oder die Freiluftbühne, die man für ein Konzert errichtet hatte (p. 54).

Dalton is a romantic figure, a latter-day version of the Western outlaw who rebels against the strictures placed on his being by an excessively civilised community. His revolt is presented by Roth with utopian overtones as the revolt of the desire for integrity and self-knowledge against a life of compromise and illusion. Roth's interest in popular American music may have led him to the name 'Dalton'. A widely broadcast song by the American rock band, 'The Eagles', first released in 1973, tells the story of an outlaw named

${ }^{192}$ Ulrich Greiner, 'Ein Mord, eine Verfolgungsjagd und die unstillbare Sehnsucht jemand anderer zu sein'. 
Dalton. ${ }^{193}$ In the novel, Dalton's strong persona exercises a magnetic attraction for Weininger's inchoate sense of identity and seduces him unwittingly into naïve acts of imitation. He is drawn to Dalton's girl-friend, becomes interested in the same antiques and is surprised to find himself in an expensive clothing store buying a shirt identical to one he has seen Dalton wearing (p. 57).

Dalton's anarchic bid for freedom reflects Roth's fascination at the time of writing Ein neuer Morgen with the radical break with conformity to the conventional social and familial patterning of male existence represented by what he conceptualised as 'die Möglichkeit des Untertauchens' (Interview 1). Dalton's need to escape from his role as a mid-Western bank executive and family man leads him to commit a 'white-collar' crime, to embezzle some $\$ 200,000$ and, deserting his wife and children, to go underground assuming another identity. Roth attributed the actual impetus for Dalton's story to an article he had read in 1975 in Die Zeit, 'wo zu lesen war, daß jährlich 400,000 Amerikaner ihre Familien für immer verlassen - sie gehen aus dem Haus unter dem Vorwand bloß eine Packung Zigaretten zu holen und kommen nicht mehr zurück'. ${ }^{194}$ Dalton finds himself pursued, not by official agents of the law, but by the corrupt private detective and blackmailer, Olson, sent after him by his wife. Olson in his turn is pursued by two violent, small-time criminals, the identical twins Douglas and Emil Knight, one of whom he had double-crossed in jail, and who have now found out about his attempt to blackmail Dalton. Dalton is chased across the United States to New York where Olson arranges for him to go into hiding while he deals with the Knight twins. It is just at this point that Weininger enters inadvertently into the affair.

Weininger can sympathise with Dalton's primary motivation and in a number of ways finds Dalton an attractive figure. The longing to escape from what the American sociologist, Richard Sennett, characterised in the later 1970 s as 'the tyranny of intimacy' is deliberately placed by Roth at the heart of Dalton's flight from the decent society of middle America. The figure of Dalton reflects Roth's own interest as a young literary artist of Austrian middle-class background already living apart from his wife and children, in acts of rebellion against a life of unreflective conformity to the wishes of others, against the suburban limbo depicted by Sennett:

${ }^{193}$ 'Doolin-Dalton', Frey, Southner, Henley and Browne (Benchmark and Kicking Bear Music, 1973).

${ }^{194} \mathrm{G}$. R. cited by Reinhard Gruber, 'Wird es ein Bestseller? Gerhard Roth: Ein neuer Roman und viele Pläne', Neue Kronen-Zeitung, (Graz), 8 February 1976. The publisher's blurb inside the front jacket of the first hardcover edition includes the following quotation: "Jährlich werden in der Bundesrepublik 50.000 Menschen als vermißt gemeldet. Warum verschwinden sie von heute auf morgen aus ihrer gewohnten Umgebung? Fliehen sie, wie amerikanische Untersuchungen nahelegen, aus den Zwängen und Belastungen der Industriegesellschaft?" The source is given as Die Zeit, 7 November 1975. 
... a life limited by children, mortgages on the house, quarrels with one's spouse, trips to the vet, the dentist, the same hours for waking, catching the train to work, returning home, the careful drinking of two martinis and the smoking of eight cigarettes which is each day's ration, the worry over bills a catalogue of domestic routine soon produces one image of intimate tyranny; it is claustrophobia. ${ }^{195}$

In Horizont, Roth had brought Haid to the painful realisation that he has avoided facing his fear and uncertainty about life by retreating into fantasies of himself as the detached observer and acting out fantasy roles as detective or criminal. Unlike the markedly artificial figures einstein, Kalb, or Künstel, Haid could not find more than briefly convincing refuge in states of madness. In Ein neuer Morgen, Roth explores a further branch of the dilemma arising from the experience of a radical displacement, this time in the form of flight from the social role of an average 'family man'. Dalton's flight from the unbearable averageness of suburban family life immediately places him on the wrong side of decent society and the law. He becomes a criminal outsider who must face terror and loneliness in order to survive. Weininger's involvement with Dalton and in the consequences of Dalton's crime is apparently a matter of chance but his interest in Dalton in fact corresponds closely to his own latent desire to make a comparable break with his past and begin a new life, to enter into the 'new morning' ${ }^{196}$ of the novel's title.

In adapting the detective genre to his own aims, Roth has dispensed with the outward trappings of the traditional detective role, while preserving the spirit of the 'search for a hidden truth'. Chandler's Marlowe lives on the edge of American society and finds little satisfaction in his personal relationships or in the way most people live. He tends to act more as a private citizen than as an agent of the law. He holds the efficacy of the justice system in cynical contempt: he knows that the law is corrupt and pursues instead his own very personal notion of justice. Where he can, Marlowe enforces his own moral judgements in preference to a strict reading of the legal code. In Morgen, Weininger acts wholly for private and personal reasons. His personal 'enquiry' into Dalton's 'case' pushes beyond normative concepts of law and order to the eventual revelation of the real motivation behind Dalton's actions. Unlike a detective, however, Weininger does not pursue matters actively as Marlowe or even Haid might have done, but adopts instead the more passive stance of an observer who finds himself drawn into a situation whose outcome interests him immensely but who remains uncertain as to how he should proceed. He watches Dalton and waits for the clue which will guide his next move. In a

\footnotetext{
${ }^{195}$ R. S., The Fall of Public Man, (New York, 1977), p. 337.

${ }^{196}$ The title also makes reference to American popular music: 'New Morning' is the title of an album released by Bob Dylan in 1970 .
} 
further departure from the expectations of the detective genre, in the end, it is Dalton and not Weininger who reveals the hidden truth.

Like all Roth's previous protagonists who as emotionally avoidant, socially isolated, cerebral 'Beobachter' often exhibit a strong bias toward the visual dimension, Weininger is a compulsive observer and, as a professional photographer, falls readily into the role of 'private eye' who watches from a discrete distance and whose camera sometimes functions both as pretext and as defensive cover. When he finds the body of Emil Knight in Dalton's room, for example, he is gripped by panic when he hears cracking sounds but his first reflex is to take a photograph of the scene and remove a photograph of Patricia which might have implicated her in the murder (p. 46).

Although he is sometimes compared unfavourably to Haid, Weininger is much closer to realising the state of awareness towards which Haid was working in Horizont - the ability to see the world as a series of images, to assimilate reality without judging it, and to be concerned only with the particular truth of each experience. His interest in developing this aesthetically centered way of seeing is outwardly expressed in his role as a photographer. Weininger arrives in New York with no specific historical or social interest in America and instead reads the images he makes in the city as possible clues in his private quest to come closer to what he suspects might be the concealed reality of events and therefore arrive at a better understanding of his own far from certain sense of identity as a professional maker of images. Some time after his initial encounter with Dalton, he notices that a change is taking place in his way of seeing:

Weininger leitete nichts von den Bildern ab. Er bemerkte, daß es angenehm war, aus dem Fenster zu schauen und die Zeit vergehen zu lassen. Für ihn war sonst jedes Bild etwas Losgelöstes, das er wie etwas Abgeschlossenes betrachtet hatte. Jetzt aber schien ihm alles voll Sinn, und es war ihm, als habe er eine Entdeckung gemacht (pp. 77-78).

Certain descriptions of New York, especially those directly connected with Weininger's photographic explorations, are rendered with great precision and clarity. These images of America, which are strongly evocative of the actuality of everyday life in New York, are an integral part of Weininger's attempt to explore his own experiences as he searches for a new mode of existence.

Casting Weininger in the role of photographer not only motivated the photorealistic accuracy of his depiction of New York scenes but also allowed Roth to utilise in a very direct way his own experiences there as a young Austrian literary tourist and skilled amateur photographer. ${ }^{197}$ The photographic material

${ }^{197}$ The first public exhibition of Roth's photographs took place in 1980 in Graz (Kulturhaus) and in Villach (Gallerie an der Stadtmauer). Katalog: Fotos zum Roman Der stille Ozean, (Kulturreferat der Stadt Graz: Wien/Graz, 1980). 
he acquired as the result of his extensive flânerie on his first two trips to America laid the foundation for the compositional technique of the 'FotoNotizbücher' which he compiled while travelling and later utilised extensively during the process of writing. What Weininger photographs forms a part of the diegetic world of the novel: because the scenes he photographs are nearly all based on Roth's own New York slides and prints, these passages tend to convey a vivid sense of actuality. Other scenes connected with the criminal action, such as the final shoot-out (p. 140), are more cursorily sketched and somewhat clichéed because they rely to a great extent for their effect on the author's exploitation of the ready familiarity of most of his readers with the images from popular American crime fiction and detective films which they tend to evoke. As Lothar Baier commented:

Amerika hat den Vorzug, im Bewußtsein der Leser oder Zuschauer bereits zu existieren, wenn es nur beim Namen genannt wird. Keine fremde Kulisse muß mühsam aufgebaut und ihre Topographie vermessen werden; denn wie Amerika aussieht, das weiß der Leser aus zahlosen Büchern und Filmen mehr als genau. ${ }^{198}$.

The fascination with and, in part, the ready susceptibility of many of Roth's generation to subcultural manifestations of the crime and corruption in American society allow such images to function as a lingua franca and provide the wider cultural context in which Roth encountered the 'Chandler Krankheit' that in different ways besets both Haid and Weininger. The bright and sometimes lurid currency of American urban myth exuded an irresistible allure for a generation that had actively rejected much of its own Austro-German cultural inheritance as either suffocating or ideologically suspect.

The notable difference in quality between Roth's quite frequent recourse in the text to the shared and infinitely repeatable genre iconography of crime film and fiction and the passages depicting Weininger's photographic observations resides in Weininger's (and Roth's) search for the unrepeatable singularity of the 'decisive moment' which Cartier-Bresson proclaimed as the photographic moment of insight. Caught in his desire to locate through the viewfinder these spaces of personal ontological significance, Weininger is, as his creator was while in New York, always on the alert for a likely shot, even though he can also experience a certain revulsion at his compulsion to capture images (pp. 6263), especially when the gesture of photographing a person or an event exposes his lack of clear purpose or serves as a cover to mask his anxiety or fear of others as is evident in his encounter with the derelict figure in Harry's Bar (p. 135). In the quiet periods between his adventures in connection with the Dalton affair, he continues to roam the streets of New York with his camera.

${ }^{198}$ Lothar Baier, 'Ein neuer Morgen', Westdeutscher Rundfunk, broadcast 20 April 1976, (transcript) p. 1. 
A number of scenes which Weininger photographs can be linked directly to the New York photographs Roth published in manuskripte in 1975 prior to the publication of the novel. ${ }^{199}$ The importance of these images for Morgen lies less in their aesthetic quality as photographic decisive moments (while they are of above average competence, only a few are visually arresting), than in the quotidian sense of actuality their verbal translation brings to the New York setting. The images reproduced in manuskripte include an oddly dressed black woman (p. 50), a Jewish shopkeeper (pp. 56-57), a group of young blacks playing steel drums (p. 57), an inscription advertising a Mick Ronson concert (p. 80), the Gordon's Gin sign and neon news ticker in Times Square (p. 81), and an enormous letter ' $C$ ' painted on a rock face on the Hudson River ( $p$. 129). An example of Roth's concern with veracity is revealed in a comparison of the scene depicting Weininger's encounter with the Jewish shopkeeper with the corresponding photograph in manuskripte. The photograph shows a greybearded man, wearing a black yarmulka and a white, short-sleeved shirt, standing in the doorway of what is evidently a menswear shop. Behind him a rack of ties is visible. He is holding up his right hand level with and slightly to one side of his face and appears to be smiling. The author's description of what Weininger 'sees' brings out every significant visual detail of the photographic image:

Vor einem kleinen Laden stand ein Jude mit schwarzem Käppchen und langem, grauen Bart. Das kurzärmelige Hemd hing ihm aus der Hose, die zerknittert und ohne Bügelfalte war und von einem schmalen Gürtel zusammengehalten wurde.

Die Tür zu seinem Geschäft war offen, und Weininger sah einen Ständer mit breiten Krawatten, die gestreift oder getupft oder mit orientalischen Mustern bedruckt waren.

Als der Jude merkte, daß Weininger das Geschäft betrachtete, griff er nach hinten und hielt ihm aufmunternd ein Büschel Krawatten hin, und Weininger griff zur Kamera, worauf der Jude mit hochgezogenen Schultern im Geschäft verschwand. Vorsichtig spähte er durch die Tür, und als Weininger keine Anstalten machte zu fotografieren, kam er wieder heraus, und Weininger fotografierte ihn, als er gerade die Hand hob und sein Gesicht verdecken wollte. Als Weininger später das Bild entwickelt vor sich sah, bemerkte er, daß der Jude lächelte. Es war ein nachsichtiges, menschliches Lächeln, das Weininger sehr gefiel.

Of necessity the narrative depiction of the image broadens the frozen moment by inserting it back into the temporal flow of the events Weininger's behaviour with the camera has initiated. The fact that it is only later on the basis of the

${ }^{199}$ G. R., 'Aus den Fotonotizbüchern Amerika von Gerhard Roth', manuskripte, No. 50, 1975: photo insert between pp. 192-193. 
developed image that Weininger is able to interpret the events he has captured on camera in the street and register them as affect also provides an insight into the function of Roth's 'Foto-Notizen' as an aid to filtering and later interpreting the flood of images his travels exposed him to.

A further example of the way Roth's detailed observations provided the basis for the America we encounter in Morgen can be derived from a comparison of the passage where Weininger visits the New York Night Court (pp. 35-42), with the article he wrote on his visit there with Wolfgang Bauer for the Graz edition of the Neue Kronenzeitung (See Note 188 above). The scene is essentially the same in both versions. Apart from the inclusion in the newspaper version of a short introductory paragraph listing New York crime statistics, the passage in the novel reads like an expanded form of the article with a heightening of descriptive detail and the inclusion of some conversational exchanges Weininger overhears. In both, a subjective response to the recording and interpretation of events prevails. In the newspaper article, Roth describes '[e]ine alte, blasse Frau wie aus einem Hitchcock-Film, mit weißschwarzgemustertem Staubmantel und einer schwarzen Handtasche, die sie gegen ihren Bauch preßt, ...'. In Morgen, the same figure appears: 'Eine ältliche Frau saß im schwarzgestreiften Staubmantel in der letzten Reihe und preßte eine Kunstledertasche gegen ihren Bauch, als hätte sie Angst, sie könnte ihr entrissen werden' (p. 35). To Roth in the article and to Weininger in the novel, events in New York's Night Court convey the sense of a meaningless ritual and both texts present the reader with a negative view of the American justice system. This impression is reinforced in the novel as Weininger reenters the courtroom: 'als Weininger die silbernen Relieffiguren auf der Tür sah: Justitia mit der Waage und Moses mit den Gesetzestafeln, kamen ihm die Symbole wie eine Ausrede vor' (p. 40). Weininger's later meanderings in the Bowery and the description of the human wreckage in Harry's Bar (pp. 134136) intensify the impression of the dark underside of New York life. At the heart of New York Roth discovers chaos: he makes Weininger a witness to the effects of a minor hurricane on the city, presaged by the news ticker in Times Square, which brings fire and looting in its wake (pp. 93-96).

These negative images are partly countered by other, more positive shots of the everyday life of New Yorkers, especially the scenes Weininger registers when he is killing time in the city while staying out of sight of Olson (pp. 122132). Among the events which engage his attention are a group of young actors working-out at an acting studio (p. 122), a business dealing in second-hand amusement arcade machines (p. 123), a family eating ice-cream in a Howard Johnson's Ice Parlour (p. 123-124), and a violet bicycle painted on a warehouse wall (p. 124). Weininger takes a sight-seeing trip on New York Harbour and is ferried past Ellis Island and the Statue of Liberty. He travels further on the East River, the Harlem River and the Hudson and catches glimpses of New York from several angles. Back on shore, he visits the restaurant on Times Square belonging to the former world champion boxer, Jack Dempsey, whom he 
photographs as he leaves. Although these images are typical of a tourist's rapid trajectory through the city, they are presented in a manner which enhances the sense that Weininger is firmly located in the New York of consensus reality.

The final image of New York reinforces the sense of the city's latent chaos and the necessity of breaking away. In the midst of the Easter costume parade on Fifth Avenue, Weininger and Patricia are caught up in the shoot-out between Douglas Knight and Olson. Here chaos mingles with the grotesque: 'über die Fahrbahn und die Gehsteige bewegte sich eine große Menschenmenge in bunter Verkleidung; maskiert, geschminkt, zu kleinen Prozessionen formiert, spazierten sie zwischen den alltäglich gekleideten Fußgängern' (p. 137). Knight is wearing an outsize sombrero and his fingernails are goldlacquered. Olson is dressed as an old, white-bearded man and has a young girl on each arm. He hands a package to Patricia which Knight tries to intercept. Olson shoots him down and is himself shot by the police as he runs away. The carnival atmosphere of Fifth Avenue contrasts bizarrely with the shooting and contributes to a narrative derealisation of the city. The effect is dream-like, nightmarish and cinematic. Weininger can think only of leaving America: there is nothing further he can find out in New York. Dalton has already left for Europe, an American on the run from the vacuous suburban reality of the American Dream. Weininger will follow him with Patricia to learn from him what he can: 'da nur Dalton wirklich wissen konnte, was geschehen war ...' (p. 141).

Reversing the usual explanatory logic of the detective genre, in Cannes, the 'criminal', Dalton, tells the 'detective', Weininger, the story of his overwhelming desire finally to be himself. These final pages of the novel are written in a simple but compelling style and clearly portray Dalton's emergence from a state of suburban unconsciousness of his needs and wishes:

Ich hatte mich so lange gedankenlos wohl gefühlt, bis ich bemerkte, zu welcher Alltäglichkeit es mir geworden war, die Unwahrheit zu sagen, und die Einsicht mit welcher Leichtigkeit und Selbstverständlichkeit ich mich verstellte, verursachte mir körperliches Unbehagen. ... Ich kam darauf, daß die meisten Menschen erbärmlich seien und feige sind. ... Ich wollte mich nicht mehr ausplündern lassen, weder von der Bank noch von meiner Familie, die Ansprüche stellte. ... Alles war in schönster Ordnung, solange ich nicht darüber nachdachte. Man muß sich den Ordnungen automatisch fügen, dann läuft das Leben wie von selbst ab. Und man darf nicht darüber nachdenken, wieviel Unverschämtheiten man Tag für Tag ausgesetzt ist (pp. 160-164).

A central theme in Roth's work, already evident in Haid's efforts to be more honest in his thinking and behaviour, is the very real difficulty, and simultaneously the psychological necessity of positive self-assertion ('sich selbst behaupten'). From the opposite side of the coin comes the temptation to abandon 
oneself passively and conform ('die Verführung sich selbst aufzugeben'). The ability to be oneself, however, very much depends on the opportunities for meaningful self-expression provided by the immediate social and cultural environment. The search for such opportunities against the pressure to conform to social demands is the operative force within the split psyche of Roth's protagonists and a dominant theme in the two 'Amerika-Romane'. If Weininger adopts a romantic view of Dalton, almost idealising his rebellion and flight across the boundaries of social custom and the law, Roth allows Weininger's actual behaviour to remain much closer to the position of the average citizen Dalton is determined to leave behind. And despite his sympathy for Dalton, he remains clear about the relationship of this figure's to his own identity:

... ich glaube, daß ich selber dem Weininger ähnlicher bin als dem Dalton. Dalton ist eher ein passiver Typ - jahrelang, bis zu seinem 50. Lebensjahr, bis ihm plötzlich bewußt wird, daß er in einer Bewußtlosigkeit liegt (sich befunden hat) bisher. Er reflektiert darüber, und es gibt eigentlich keinen anderen Ausweg als die Flucht. ${ }^{200}$

In Morgen, the modus vivendi adopted by the photographer, a life of reflection and aesthetic practice, rather than anarchic criminal adventure can be seen on balance to be the preferred counter-strategy for living against the threat of a deadening suburban existence. In the next novel, Winterreise, which is set in Italy, Roth poses further questions about the predicament of an individual for whom the system of values on which his social existence is based collapses under the weight of despair into an experience of meaninglessness from which he can find no socially acceptable means of escape.

\subsubsection{Winterreise}

Roth first conceived of the book which eventually became the novel, Winterreise, as a story about his grandfather: 'Ich hatte ursprünglich vor, eine Geschichte über meinen Großvater zu schreiben' (Interview 1). Roth had both loved and admired his grandfather whose stories he had listened to as a child with endless fascination. But he felt that he could not simply relate the story of his grandfather's life and the socialism in which he had so strongly believed without including a counter-image from his own time. The mid-1970s was a time of great political division over the issue of terrorism in West Germany. Against the background of such events as the assassination of the West German State Prosecutor, Buback, the kidnapping and murder of the President of the Employers Federation, Schleyer, and the suicide of Baader-Meinhof members,

\footnotetext{
${ }^{200}$ Sigrid Esslinger, 'Gerhard Roth: Ein neuer Morgen'.
} 
Baader, Ensslin, and Raspe, ${ }^{201}$ Roth sensed that even in Austria the atmosphere was such that a simple account of his grandfather's life would appear to be a naive affirmation of a heroic form of socialism and a denial of the despair felt by many of his own generation. He did not intend that such events should be central to the novel or that the work should be documentary, but it should reflect the political and philosophical despair of the period: 'Das Buch ist nicht als Zeitbeschreibung gedacht', rather it should achieve 'die Darstellung der Verzweiflung und zwar in meiner Zeit aber nicht der Zeit' (Interview 1). In the final version, the existential elements overshadow the political which appear on the periphery in anecdotes from the life of the central character's grandfather and dramatically in the death of a young woman during a student demonstration in Rome (pp. 112-114).

The first premise on which the examination of the theme of despair in Winterreise is based is derived from Roth's reading of Freud's essay Das Unbehagen in der Kultur (1930). Roth had first encountered this essay some five years previously and found himself returning to it as he contemplated the material for the novel. Das Unbehagen in der Kultur, an important step in the development of Freud's thinking on the death instinct ('Todestrieb'), examines some of the antinomies at work within culture. Freud discusses the conflict between the pleasure and reality principles in the formation of a civilised society and the diminishing of gratification which occurs as sexual and aggressive impulses are sublimated in the comparatively subdued, 'higher' satisfactions of intellectual and artistic pursuits. Reflecting on the role of aggression and the conflict between the life-enhancing Eros and destructionseeking Thanatos, Freud concludes that the state of culture induced by Eros delivers at best only partial happiness: the pursuit of happiness dictated to us by the pleasure principle cannot be fulfilled, but neither can it be abandoned. The adequacy of Freud's model of culture cannot be examined here. What is important for Winterreise is an assumption Freud makes at the beginning of Das Unbehagen in der Kultur. Although 'das Leben, wie es uns auferlegt ist, ist zu schwer für uns', it can be made bearable by means of the three principle 'temporary measures' ('Hilfskonstruktionen') available to us:

mächtige Ablenkungen, die uns unser Elend geringschätzen lassen, Ersatzbefriedigungen, die es verringern, Rauschstoffe, die uns für dasselbe unempfindlich machen. Irgend etwas dieser Art ist unerläßlich. Auf die Ablenkungen zielt Voltaire, wenn er seinen Candide in den Rat ausklingen läßt, seinen Garten zu bearbeiten; solch eine Ablenkung ist auch die wissenschaftliche Tätigkeit. Die Ersatzbefriedigungen, wie die Kunst sie bietet, sind gegen die Realität Hlusion, darum nicht minder psychisch wirksam

${ }^{201}$ These events and other notable instances of terrorism occurred in 1977 while Roth was working on the manuscript of Winterreise. 
dank der Rolle, die die Phantasie im Seelenleben behauptet hat. Die Rauschmittel beeinflussen unser Körperliches, ändern seinen Chemismus. Es ist nicht einfach, die Stellung der Religion innerhalb dieser Reihe anzugeben. ${ }^{202}$

Freud argues that to ask the purpose of human life is to ask a philosophically improper question. Implicit in Freud's argument is the notion that when all other 'temporary measures' fail, the powerful diversion of work is capable of creating a sense of order and satisfaction within the psychological economy of the individual and society as a whole. It is with this last assumption that Roth takes issue in Winterreise:

Mein Buch geht aus von einem Aufsatz, Das Unbehagen in der Kultur, von Sigmund Freud. Es gibt ein Zitat in diesem Buch, da zitiert er Grabbe und zwar "Wir werden schon nicht aus der Welt fallen". Und Freud meinte, wenn alle Sinnsysteme, wie, z. B., Religion, versagen, daß der Sinn des Menschen in der Selbstverwirklichung, also in der Arbeit besteht. Und für mich war die Frage, was ist, wenn diese Form von Selbstverwirklichung nicht möglich ist - und ich habe den Eindruck, daß sie bei der Mehrheit nicht möglich ist - was ist also, z. B., mit jemandem, der in diesem Kultursystem, in dem ich lebe, lebt und eben diese Sinnsysteme nicht findet. ${ }^{203}$

Here Roth makes the assumption that work as it has come to be for the majority in the time since Freud wrote Das Unbehagen in der Kultur, involves a degree of alienation which enhances the sense of meaninglessness and renders the work situation incapable of diverting the enquiring spirit for long from the pain of existence: 'Das scheint mir nun von Freud zwar richtig zu sein, aber ich bin der Meinung, daß die Arbeit, die der Großteil der Menschheit ausübt, auch hier in der Zivilisation ... nicht etwas sein kann, was einen erfüllt' (Interview 1). The link here to the work of other Graz authors is strong. There is much in the oppositional character of 'Grazer Literatur' which is directly or indirectly critical of mass-production and consumerism and the degradation of work in an advanced technological society. In Handke's case, for example, criticism of meaningless toil is present in Wunschloses Unglück (1972), while the assertion of the counter-value of meaningful work becomes explicit from Langsame Heimkehr (1979) onwards. Critical reflection on the nature and value of work can be traced profitably through the novels of Kolleritsch, Frischmuth, Eisendle, and Hoffer.

${ }^{202}$ S. F., 'Das Unbehagen in der Kultur', Abriß der Psychoanalyse/Das Unbehagen in der Kultur, (Frankfurt a.M., 1972), pp. 65-129 (pp. 73-74).

${ }^{203}$ Roth on Winterreise, a contribution to the programme Diagonal on the theme of 'Winterreise', ORF (Radio), 18 December 1982. 
Roth further qualifies the argument of Winterreise in relation to the search for purpose and meaning in life by specifically rejecting the notion of the Viennese psychotherapist, Viktor Frankl, that the 'existential vacuum' caused by the sense of meaninglessness - the frustration of what Frankl terms 'the will to meaning' - can be overcome by the practice of a therapeutic 'logotherapy' ${ }^{204}$ aimed at discovering meaningful personal goals latent within the individual:

Ich glaube prinzipiell nicht an Sinnsysteme. Ich halte das, was, z. B. Frankl macht, nicht für zielführend, weil es davon ausgeht, daß es prinzipiell so etwas gibt wie einen Sinn. Nun glauben alle Leute, die keinen Sinn sehen, nur sie selber sehen den Sinn nicht. Ich glaube, daß es einfach notwendig ist, eben mit dieser Sinnlosigkeit, die es gibt, zu leben und innerhalb seines Lebens jene Punkte zu finden, die einem im Prinzip angenehm sind (Diagonal broadcast. See Note 203).

In opposing the tendency towards nihilism and seeking a basis for his definition of man as 'a being in search of meaning', Frankl makes assumptions about the universality of the 'will to meaning' based on excursions into the realm of speculative metaphysics. Roth found this explanation with its tendency to promote a universal system inadequate.

One of Roth's comments on the making of Winterreise touches directly on that feature of 'Grazer Literatur' which has provoked some of the most negative response from its critics and led Greiner, amongst others, to highlight the 'Flucht- und Verweigerungscharakter der Grazer Literatur' . 205

Contemplating the root cause of the sense of despair engendered by the impossibility of finding adequate fulfilment in work, Roth postulates in the novel the case of someone for whom this situation is rendered all the more unbearable by 'die Unveränderbarkeit der sozialen Wirklichkeit': 'Und wenn sich dieses Gefühl der totalen Unzufriedenheit nun verstärkt in einem Menschen zeigt und es die Unveränderbarkeit der sozialen Wirklichkeit denn gibt, kann ich mir vorstellen, daß das die Ursache für eine Verzweiflung ist' (Interview 1). It is an issue which Greiner has directly addressed. In Der Tod des Nachsommers, he qualifies and extends Magris's sociological analysis ${ }^{206}$ of the retreat from reality evident in Austrian literature. Greiner presupposes that

${ }^{204}$ Frankl's Logotherapy, sometimes called the Third Viennese School of Psychotherapy, is an attempt to humanise psychoanalysis and behaviouristic psychology by countering the reductive effects of the scientific positivism on which they are based. He replaces Freud's 'will to pleasure' and Adler's 'will to power' with the 'will to meaning'. See, for example, The Will to Meaning: Foundations and Applications of Logotherapy, (London, 1971) or The Unheard Cry for Meaning, (London, 1979).

${ }^{205}$ Der Tod des Nachsommers, p. 208.

${ }^{206}$ See Note 31 . 
'literarische Produktion ist ja sehr oft Ausdruck einer Selbstverwirklichung, die anders nicht stattfinden konnte ${ }^{, 207}$ - a view held by many West German critics. He observes that the notion of the powerlessness of the individual to alter oppressive social conditions is particularly strong in the mainstream of Austrian literature from the time of Grillparzer to the present. The authoritarian nature of Austrian political institutions, which in the nineteenth century made it impossible for an Austrian writer to be both a patriot and a revolutionary, has resulted in a continuing rift between Austrian intellectuals and the apparatus of the state. In Austria, the world of literature tended to become a place of inner refuge, the only remaining territory for the self-realisation and effective action which external social and political conditions continually worked to frustrate: 'eine Literatur, ob bei Stifter oder Handke, die antirealistisch und apolitisch ist, die gleichwohl ein großes menschliches Paradigma darstellt für die Not des Nichthandelnkönnens und ihrer Transformation in ein Reich der Sehnsüchte und Hoffnungen' ${ }^{208}$ Greiner sees this tendency in the work of the Graz authors. He argues that 'die rationale Auseinandersetzung mit einer weithin irrationalen Umwelt' does not take place: 'Das Bewußtsein, nichts ändern zu können, mündet in Resignation und baut sich ein eigenes Reich, wo die Gesetze der Konvention nicht gelten. Das erklärt auch, weshalb die Grazer Literatur weithin unpolitisch ist. Ihre Opposition bleibt literarisch, sie versteht sich nirgends explizit politisch' ${ }^{209}$ But, as has been noted in the general outline of Greiner's analysis (pp. 79f), in contrast to the reductive politicising of some West German authors, he also regards this as a major strength of 'Grazer Literatur': 'Die Grazer beharren auf der Andersartigkeit und Besonderheit von Literatur, die sich keinen Rastern einordnet. Gerhard Roths Aversion gegen die "Klassifizierungsidioten" hat da ihren Ursprung'. ${ }^{210}$ Greiner is fair-minded in his treatment of the relationship between 'Grazer Literatur' and the social dimension. But, like many other critics of the Graz phenomenon, he continues to underestimate the degree to which Roth and other Graz authors accept that language determines consciousness and therefore the nature of political and social events. Furthermore the experimental, 'what if?' character of much of 'Grazer Literatur' remains in the background. In Winterreise, Roth is not insisting that social reality is completely unalterable. He argues only that the experience of alienation and powerlessness in the work situation is widespread and that, in the hypothetical case of his protagonist, it has become a genuine cause of despair. The dependence on language and unquestioned ideological representations of the social order which form the basis for this predicament in

\footnotetext{
${ }^{207}$ ibid., p. 13.

208 ibid., p. 13.

${ }^{209}$ ibid., p. 208-209.

${ }^{210}$ ibid., p. 209.
} 
the novel, becomes clearer in a further comment made by Roth on the way the myth of fulfilment in work depends on the manipulation of appearances:

Dieses geheime Leben, das man nach außen hin führen muß - daß eben die Wirklichkeit nur deswegen so ausschaut, weil wir uns immer nach dem anderen richten, so daß wir denken, was er mag. Wir richten uns oft nach dem Scheinbild des anderen und erzeugen selbst auf diese Weise Scheinbilder. Wir machen gegen die Kultur keine Möglichkeit der Veränderung. Das, was wir als 'Eingesperrte', sozusagen, erleiden müssen ... daß wir uns nach einer bestimmten Form verhalten müssen, weil der Nachbar oder die anderen Leute sich genauso verhalten, und daß wir dann alles nur geheim machen, das bedingt ja gleichzeitig den Zwang, den andere empfinden. Wir arbeiten an diesem Zwang, sozusagen, mit (Interview 1).

There is no sense here of a conscious conspiracy aimed at keeping citizens in their place. It is the end result of the same failure to be honest with oneself and others which so disturbed Haid in Der große Horizont. In Winterreise, as in Morgen, Roth contemplates the predicament of someone whose need to come to terms with the world he actually perceives will no longer let him play the game according to accepted rules. His protagonist flees from the unbearable narrowness and repression which his previous life as a good, thoroughly average citizen has entailed.

Roth found that of all his novels up to Landläufiger Tod, it was the ideas on which he based Winterreise which were the most misunderstood by critics even though the novel itself received high praise from many quarters:

In dem Roman Winterreise, da ist das Philosophische, Existentielle vor dem Politischen, d. h., hier geht es mir mehr um eine allgemeine philosophische Situation als um eine politische, wenngleich es aber auch hier ein politisches Umfeld gibt, in dem man sagt, diese Form des Lebens gibt es in einem Staat, in dem es zumindest in keinem sehr überblickbaren Ausmaß Elend gibt. Es gibt noch eine andere Form von Elend als das soziale Elend. ... Die Winterreise ist am meisten mißverstanden worden in dieser Beziehung. Weil ich da eine Form des persönlich erlebten Nihilismus beschreibe, wird mir unterstellt, ich beschriebe ein Programm des Nihilismus, was überhaupt nicht der Fall war. Mich hat die philosophische Basis dieser Geschichte interessiert. Es ist auch doppelt interessant, daß gerade von ideologischen Seiten die meisten Einwände waren. Denn der Marxist, dem ist noch lieber der Katholik als der Nihilist und umgekehrt (Interview 1).

There is one point on which Frankl and Roth concur, namely that in a modern welfare state such as Austria, improving the socio-economic situation of the 
people has not added much to the sum of human happiness. The struggle for survival has subsided but the state provides no answer to the question which preoccupies all the Graz authors: survival for what?

The title of the novel is taken from Schubert's song-cycle Die Winterreise (1827), but Roth emphasises that he took the 'Winterreise' theme in its most general sense, as a journey taken out of despair, not as a heavily symbolic reference to the actual content of Schubert's work. Roth himself made a journey to Italy to research the novel in February 1977. It is not the case that he deliberately chose a winter setting for the novel. The winter of 1977 was the only time he was free of the other literary commitments he had taken on during the latter part of his year's leave of absence from the Graz computer centre. Roth does not deny the right of critics to find symbolic connections in Winterreise but stresses his own dislike of symbolism and the fact that, from his point of view, the essential concerns of the novel could just as well have found expression against the backdrop of an arid or steamy Italian summer. As in all of Roth's novels there are links to the preceeding work. Ein neuer Morgen takes Cannes on the Mediterranean coast as its final setting thus bringing Weininger back to the Europe Haid departed from in Horizont. As Weininger prepares to leave New York his thoughts turn to what Europe might hold for him: 'Der Gedanke, bald in Europa zu sein, erschien ihm wie ein großes Versprechen' (p. 141). There is a foreshadowing of the journey to Naples and Vesuvius in Winterreise when Weininger notices a picture on a packet of spaghetti carried by a man in a New York subway train:

Vermutlich stellte es die Bucht von Neapel dar, denn vor einem blauen und gelben Himmel erhob sich ein feuerspeiender Vulkan, dessen Hänge von roter Lava bedeckt waren.

Andere Berge hatten grüne Hänge, und das Grün lief bis zum Meer aus, auf dem Segelboote dahintrieben. In der Mitte des Bildes befand sich von gelben Ähren umrankt die Gestalt einer Frau, die unter einem Arm ein Bündel Kornähren hielt. Mit der Hand des anderen Arms stützte sie sich auf ein Schild, auf das ein weißes Kreuz über rotem Grund gemalt war. Wie schön, dachte Weininger und betrachtete den Mann (pp. 48-49).

While laying the groundwork for the novel Roth had various images of a volcano in his mind: the pre-Socratic Greek philosopher, Empedocles, hurling himself to his legendary death in the crater of Mt Etna, illustrations from a book on volcanoes he came across, and a recollection of a film he had seen in which a wedding is occurring with a volcano in the background (Interview 1). Finally, there is a link to Der große Horizont through the story of the grandfather. In Winterreise Roth draws extensively on material from the life of his own grandfather. The story of the stowaway who failed to reach America - 
Haid's grandfather in Horizont - is much expanded and becomes an important point of reference for his new protagonist.

Winterreise is composed rhythmically as a harmonious arrangement of perceptions expressing the major themes. It is not in any sense a sustained narrative of conventional realism, but a subtle interweaving of thematically linked strands of perception, memory, and reflection. In the 'Kurzromane', Roth had worked exclusively with 'das Fragmentarische'. His desire to find a focus for more autobiographical and historical materials and confront questions of an existential nature led him to experiment with the role of 'Erzähler'. 'Ich will ein Erzähler sein' was a much quoted comment he made to Ulrich Greiner in $1976 .{ }^{211}$ It is a remark which should be treated with caution. The element of consciously directed narration in the sense of the deliberate telling of a story, is present to some extent in Der große Horizont and is even more marked in the suspenseful thriller storyline of Ein neuer Morgen. Roth had proved to himself that he could successfully 'tell a story'. In Winterreise, his tendency to structure the text around perceptual fragments is again on the ascendant. 'Der Mut zum Fragmentarischen' (Interview 1), which Roth later felt to be supremely exemplified in Melville's Moby Dick, gains momentum in the following novel, Der stille Ozean, to culminate in the myriad interlocking fragments of Landläufiger Tod. The story element in Winterreise is reduced to a minimum. The narrative effect arises largely from the rhythmic accretion of fragments.

The major themes of the novel: the failure of the principle of work to sustain the sense of meaning, sexuality, despair, flight, loneliness, and death, all emerge in the first of the sixty-five short chapters into which the text is organised. Winterreise opens on the last day of the year in an unnamed town or city in Austria. Nagl, a primary school teacher, reflects on the resentment and humiliation most people experience, yet readily repress when they surrender themselves to the conformity demanded of them by society: 'Es schien Nagl, als sei es das Normalste, sich selbst aufzugeben. Jeder wehrt sich dagegen, bis der Widerstand erlischt und die Selbstaufgabe den gemeinen Haß erzeugt, zu sehen, wie sich auch die anderen aufgeben' (p. 5). He sees a shoemaker at work and in the workshop a paraffin lamp with an elaborate glass shade of the type his grandfather had made around the turn of the century. He takes leave of a woman with whom he has been having an affair, the wife of a local policeman. He has decided that he does not want her to come with him to Italy. $\mathrm{Nagl}$ meets up with a funeral procession. He notices the signs of loneliness and tribulation on the faces of the adults and the anxious obedience of their children: 'Der Tod, die Einsamkeit, die Finsternis waren ihnen nicht fremd' (p. 7). He enters the school where he teaches and sits meditatively as he likes to do in the empty classroom. He likes the tools of his profession and is not averse to

${ }^{211}$ U. G., 'Ich will ein Erzähler sein: Porträt des Schriftstellers Gerhard Roth'. 
working hard. Nagl recalls a visit he made once to the open-air museum in Stübing where the walk-in exhibits represent the living and working conditions of earlier times. He remembers the darkness which seemed to prevail in the houses and workrooms and the fairy-tale atmosphere of a votive picture which hung on a wall dedicated in thanksgiving to the Virgin Mary for the recovery of a sick child. It occurs to him that it might be wise to entrust himself to life: 'sich dem Leben anzuvertrauen, wie man sich dem Tod anvertraut, auch wenn die Nähe zum Leben eine Nähe zu den Schrecken des Lebens bedeutet' (pp. 910). Later, outside he watches some children playing. A blue helicopter flies overhead and shrinks to a dot as it disappears into the distance. He thinks of the volcanoes he has read about and that the time has finally come for him 'in Pompeji zu verschwinden oder sich in den Vesuv zu stürzen' (p. 11). He goes home, looks at a finely engraved pocket-watch he has inherited from his grandfather. It occurs to Nagl that Anna, a woman who had once deceived him, might come with him to Italy. To his surprise she agrees. As he is leaving for the station he is confronted by the policeman. The man is drunk and consumed by jealousy. He shoots himself in the hand. Nagl takes him inside, dresses the wound as best he can and goes on his way: 'Die Wolken flogen tief und schnell, und als Nagl aufschaute, kam es ihm vor, als blicke er in ein gewaltiges Meer über seinem Kopf, das über die Erde strömte' (p. 14).

It is on the night-train to Italy that the significance of this closing sentence of the first chapter becomes apparent. Nagl pictures the earth as he once saw it in a coloured photograph, 'eine vereinsamte, saphirblau und weiß gemaserte Kugel in der Schwärze des Universums, ein winziger Körper der im Nichts schwebte' (p. 15). He ponders the many details through which the unseen totality of the world is perceived in everyday life and the way the image of the whole becomes ever more elusive the more one gives attention to the particular. From a distance, the planet and life itself appear wonderful and mysterious. He imagines the earth as it is from an immense distance, as if he is no longer living on its surface and its inhabitants are no longer visible. Nagl has the feeling that he has fallen out of the world - 'das Gefühl, als sei er aus der Erde gefallen' (p. 15) - and experiences this as an 'oceanic feeling filled with loneliness' - 'ein ozeanisches Gefühl voller Einsamkeit' (p. 16). In the opening paragraphs of 'Das Unbehagen in der Kultur', where he discusses the origins of the impulse towards religious or mystical feelings, Freud cites the 'ozeanisches Gefühl' which Romain Rolland believed to be the actual source of such intimations. Freud could find no trace of this 'oceanic feeling' in himself but relates it to a line from Christian Dietrich Grabbe: 'Aus dieser Welt können wir nicht fallen'. ${ }^{212}$ This, Freud interprets as 'ein Gefühl der unauflösbaren Verbundenheit, der Zusammengehörigkeit mit dem ganzen der

${ }^{212}$ D. C. G., Hannibal (1835): Freud abbreviates the original which reads: 'Ja, aus der Welt werden wir nicht fallen. Wir sind einmal drin'. 
Außenwelt' and sees it as being more a product of intellect than emotion. Nagl's apprehension of an 'oceanic feeling' contradicts both Freud and Grabbe. It is embedded in a complete dissociation with the world around him: 'Von weitem, im tiefschwarzen Meer, sah er die blaue Erdkugel, die seinen Alltag mit sich trug. Es war ihm, als hätte er nichts mehr damit zu tun' (p. 16). He considers that this mood may perhaps be a luxury in which he is indulging, but the feeling persists. Until now the deceptive nature of close appearances has kept Nagl trapped in the obvious. It has led him to repress his own thoughts and political views, to submit himself to the wishes of his employers and to inculcate in his students socially approved values which he himself cannot accept. He knows that to be genuine, 'ein Leben mit Werten' must be radical 'ein Leben mit Wahrheit' (p. 17). He senses a desire to resist. At the same time, he knows that such resistance is hard to sustain. Nagl's new perception of the world, of life itself from afar, paradoxically combines the cold foretaste of death and the impression of a severe beauty which does not seem to exclude the possibility of meaning and survival: 'Dann dachte er an die niedrig fliegenden Wolkenströme, an die Kinder, die beim Begräbnis unter ihnen hergelaufen waren, dann sah er wieder die Weltkugel von außen, bedeckt von weißen Wolkenwirbeln, ein blauleuchtender Planet von so großer Schönheit, als verkörpere er in der Todesstille des Weltraumes den Sinn und das Überleben zugleich' (p. 18).

The tensions Roth sets up between Nagl's situation and his recollections of the life his grandfather led, provide the novel with a structure for a dialogue between the values of an earlier generation and Roth's own. The theme which links the many fragmentary references to the grandfather woven into the text is the value of work. For Nagl's grandfather the work necessary to survival had provided a sufficient raison d'être. Unemployment was unbearable, associated with sickness and death:

Sein Großvater hatte an die Arbeit geglaubt. Die Arbeit war der Sinn gewesen, weil er nur mit Hilfe der Arbeit hatte überleben können. Es war ganz egal, wie die Arbeit beschaffen war. Ohne Arbeit zu leben, war eine schleichende, tödliche Krankheit, es war das Bewußtsein des Todes, das langsam auf ihn zukam. Und so hatte er gearbeitet von Kindheit an. In der Zeit der Arbeitslosigkeit hatte er Nächte über dem Schachbrett verbracht, mit sich selbst als Gegner, bis er wieder Arbeit gefunden hatte. ... Als er begraben wurde, wurde "Das Lied der Arbeit" gespielt (p. 68).

For Nagl the situation is reversed: survival has become a question of meaning: 'Nagl hat sein eigenes Leben nie verstanden. Er konnte es nicht erklären. Solange er arbeitete und an die Arbeit glaubte, war es nicht schwierig. Er fragte sich nicht, was geschehen würde' (p. 68). In the sleeping world beyond the 
train Nagel senses that the 'Mythos der Arbeit', the daily source of much of his estrangement from himself, has ceased to exist. $\mathrm{He}$ is astonished to realise that his only hope has been the thought of retirement, that all the effort and humiliation of his work have been to secure the most basic necessities of life, 'ein Dach über dem Kopf, Essen', and significantly, 'eigene Gedanken' (p. 19).

In Naples, $\mathrm{Nagl}$ watches a zeppelin hovering over the city. He recalls his grandfather taking him as a child to see a zeppelin. Afterwards his grandfather began to tell him how he had gone to sea as a stoker. The ports and countries he spoke of filled the young Nagl with a sense of adventure. Later, they visited a diorama in Graz where, as the three-dimensional images of great cities came up, his grandfather told him stories connected with those he had visited. The zeppelin in Naples appears now as a message from another world where all these events are somehow connected. Although the stories his grandfather relates convey a life in which the conditions of work were harsh to the point of brutality, for Nagl they are inextricably bound up with the feeling that life fifty years ago was more open and adventurous. The sight of freighters from foreign places in the port of Naples brings to mind 'die großen Schiffe mit den schwarzen Rauchwolken aus den Schornsteinen' (p. 76) which always seemed to play a role in his grandfather's stories. There is a link to the days of the Austrian Empire and, as in Handke's Wunschloses Unglück, to the 1930s. His grandfather was born in Istanbul where his own father, an Austrian glassblower, had gone to work for an Italian company. His grandfather's brother had died there and had been carried in a ship across the Bosphorus to be buried in the Christian cemetery. This story, related in more detail in Chapter 35 (pp. 101-102), links ships with death in Nagl's imagination. Visiting Solfatara and seeing the research station there which had been abandoned because the earth's crust had grown too thin, Nagl finds himself wondering why he always pictured his grandfather hunched over the chessboard in a darkened room throughout all the confusion of the dictatorial 'corporate state' introduced by Dollfuß and the Nazi era which followed. He was unemployed for five years, but never ceased to long for work: 'Obwohl er die Arbeit als Zwang empfunden hatte, hatte er sich nach Arbeit gesehnt' (p. 148). Without work, for which his chess playing was a token, he had no identity. His grandfather had been a Social Democrat and he and his brother had fought with the 'Schutzbund' against the military in 1934. He was repelled by National Socialism, but at the same time amazed that he could work again: 'Er war weiter Nichts, aber er konnte es vergessen. Er hatte an das Leben geglaubt, und dieser Glaube hatte ihm genügt' (p. 148). He campaigned for the Social Democrats after the war. At his death he was forgotten by the party he had served: the 'Sozialistische Arbeiterzeitung' even misspelled his name in his death notice 'als sei jemand anderer gestorben' (p. 80). 
In an effort to make sense of his own despair, Nagl ponders over links between his own hopes and fears and those of his grandfather. Arriving in Trieste in the middle of a freezing winter in search of a new life, his grandfather had seen snow for the first time: 'Die neue Hoffnung, das Leben, die Welt waren für den Großvater Eindrücke von Kälte' (p. 104). For Nagl the cold of the winter becomes associated with a similar hope but also with the presence of death and the end of the world. He has read somewhere: 'Das Weltmeer würde zufrieren, bis es auf den Grund erstarrte und schließlich verdunstete' (p. 23). In the market in Naples, Nagl watches large blocks of ice being unloaded and broken up to chill dead and dying fish from the boats. The story of his grandfather's attempt to reach America, to escape from the selfdestructive meaninglessness of a hand-to-mouth struggle for existence, combines hope and bitter disappointment. The grandfather had a romantic image of America as the promised land: 'Die Sonne stand auf einem riesigen Himmel, unter dem er klein dahinging. Diesem Bild reiste er nach' (p. 115). Painfully concealed in the coal-bunker of the 'Martha Blumenfeld', he gets no further than Cardiff. Penniless, he finally managed to work his passage to North Africa and eventually became a stoker: 'Er schaufelte Kohle in die Kessel. Er wußte nicht, was mit ihm geschah. ... Daß er nicht Nichts gewesen sei, habe er nur selbst gewußt' (pp. 123-124). Whenever Nagl imagines the condition of his grandfather after his death, he pictures him standing on the deck of the ship 'Skagerrak' somewhere in mid-ocean, his back to Nagl, looking to the open sea ahead. The old man is happy: 'Er hatte die Erde hinter sich gelassen, und vor ihm lag die Unendlichkeit. Sie hatte ihn aufgenommen, und er stand staunend und ungläubig und voll Dankbarkeit vor ihr und in ihm war Ruhe' (p. 155). It is an image connected to Nagl's observation that his grandfather had approached death as if he were expecting something: 'Er wußte nicht, was, er fühlte nur, daß noch etwas kommen mußte' (p. 156). Nagl was impressed by the courage with which his grandfather, not a religious man, had faced death. He had quietly accepted suffering as an unavoidable part of life: ' $E r$ hatte es als Selbstverständlichkeit hingenommen, einen Preis für das Leben zu bezahlen. Der Preis war das Leiden gewesen. Er sagte nie, daß er viel gelitten habe, sondern er erzählte vọn Leiden nur in Zusammenhängen. Das Leiden war immer mit dem Leben verbunden gewesen' (p. 156).

Reflection on the stories his grandfather told him and his memories of him, provides Nagl with the stark outlines of a human existence and a model for the contemplation of his own condition. From the recognition of their common humanity he derives a certain comfort. Through his grandfather he discovers a personal link to the processes of Austrian history and, at the same time, senses the indifference of that history to the fate of the individual. In Winterreise, as in other examples of 'Grazer Literatur', there is no trace of a sentimental or patriotic yearning for Austria's imperial past. Although he has risen socially 
above the working class, the teacher Nagl can find no greater sense of personal affirmation in the tasks assigned to him by his superiors than his grandfather had done. The essential difference between $\mathrm{Nagl}$ and his grandfather is that for $\mathrm{Nagl}$ the imperative of the work ethic fails to provide sufficient justification for continuing to live within the accepted boundaries.

The name of Roth's protagonist alludes to Johan Nagel, the central character in Hamsun's novel Mysteries (1892), and reflects Roth's continuing interest in the work of that author. As outsider figures, Nagl and Nagel share more than just their name. They have both seen through the illusory world of the ordinary citizen. Both hurtle precipitously over the narrow boundaries of their former existence and seek distraction from pain and anxiety in alcohol and sensuality. In comparison to his Norwegian literary brother, Roth's character is generally less romantic, less given to the manic and ecstatic, more existential and realist in orientation. There are, however, moments when Nagl's susceptibility to 'das ozeanische Gefühl' tips the balance towards the romantic side: when, for example, he experiences a sense of wonder at the myriad life forms which have evolved on the earth and feels 'Sehnsucht nach den Sternen, dem All, es zu sehen und zu überschauen, sich in ihm zu verlieren ... als eine Vorstellung des Jenseits' (p. 147), or pictures the universe as a 'gewaltiges Meer über seinem Kopf, das über die Erde strömte' (p. 14). Taken alone, such statements find easy parallels in Mysteries, but their wider context in Winterreise should not be forgotten. The romantic outsider, exemplified by Hamsun's Nagel, remains convinced that there is a truth to be found somewhere, but ordinary life places almost insurmountable difficulties in the way of its realisation. Nagel, who carries a phial of prussic acid in his waistcoat pocket, sees suicide as an 'escape hatch' into a blissful empyrean through which he hopes he has the courage to slip. In contrast, Roth's Nagl is less obsessively suicidal and is wholly uncertain what death will bring. His intellect will not allow him to place any faith in religion and yet he can accept that for many people the rituals of the church are a form of defence against the insanity of a life they cannot comprehend and a source of comfort in the face of death (p. 127). Roth allows Nagl to operate with an idea of truth which is largely relativised. But the longing for something greater than the ego persists. References to 'Unendlichkeit' und 'das Jenseits' do not entirely eliminate the possibility of an absolute and there are moments when it seems to Nagl that something like God must exist:

Er war vor zehn Jahren aus der Kirche ausgetreten. Wenn er in großer Not gewesen war, hatte er an Gott gedacht. Er hatte auch gebetet, wenn es ihm wichtig gewesen war, aber kaum war es vorbei gewesen, hatte er es vergessen. Manchmal war es seine einzige Hoffnung, daß es einen Gott gäbe. Wenn er vor Schmerzen und Einsamkeit mit Gott gesprochen hatte, hatte er nicht an ihm gezweifelt. Aber wenn er eintönig dahinlebte, die Stunden 
vergingen und er sich nicht spürte, hielt er es nicht für wahrscheinlich, daß Gott existierte. Manchmal spürte er jedoch, daß es ihn geben mußte. Alles bekam dadurch einen flirrenden Sinn, war nicht mehr nur vordergründig, sondern hing zusammen. ... Er hatte nur selten grundlos das Gefühl gehabt, daß es einen Gott gab (pp. 90-91).

In Rome, Nagl's attention is caught by the stone figures of the angels on the Ponte San Angelo: 'Im harten Sonnenlicht, das durch die Regenwolken drang, war es als strahlte von ihnen ein fernes Nordlicht aus, das dem Wasser unter ihnen einen silbernen Schimmer gab' (p. 101). From the riverbank below, it strikes Nagl that the angels are showing their backs to him. (A photograph Roth took in Rome of one of these angels with its back to the camera illustrates the front cover of the original hardback edition of Winterreise). In keeping with his aversion to symbolism, Roth does not permit Nagl to speculate on any connection this might have with his feelings about God or religion. It is simply stated as a fact. In Venice, towards the close of the novel, Nagl sees the figure of a golden angel glowing brightly somewhere in the direction of the Campanile, illuminated by the last rays of the winter sun. He is travelling towards it in a vaporetto and has the feeling that finally he is seeing things as they are: 'Endlich ist es wie im Leben und nicht wie im Traum' (p. 190). The figure of the angel has the effect of announcing his return to the self he has for so long felt separated from. The next morning, as he is about to leave Venice, on a flight to the 'ewiges Eis' of Alaska and the Arctic, he looks again for the angel on the skyline but cannot find it. Its absence does not deter him.

Nagl has not only turned his back on his career and on the social structure which supported it, his questioning of the fundamental values of his life also has consequences for his experience of love and sexuality. Roth's second premise, as important to the argument and atmosphere of Winterreise as his reevaluation of the role of work, derives from Camus's novel, L'Etranger (1942), which Roth read in translation. Der Fremde had fascinated Roth for some years. ${ }^{213}$ Re-reading this central work of French existentialism, Roth found himself asking a number of questions about Camus's handling of sexuality in the novel: 'Ich habe mir immer gedacht, irgendwo ist ein Mangel an dem Buch - etwas stimmt nicht. Camus hat die Frage des Geschlechtsverkehrs umgangen' (Interview 1). If a relationship similar to that which Camus postulates between Meursault and Marie were to take place in the more sexually open climate of the 1970s, Roth found himself asking, what kind of relationship would result: what is the connection between the expression of sexuality, despair, and indifference of the kind which afflicted Meursault?: 'Welche Form von Geschlechtsverkehr macht Meursault, wenn er wirklich so gleichgültig ist? Es gibt

${ }^{213} L^{\prime} E$ tranger first appeared in German as Der Fremde in 1957. 
keinen gleichgültigen Geschlechtsverkehr. ... Ist er sadistisch, masochistisch, normal? Was ist normal und welche Form der Normalität hat er?' (Interview 1). Roth also asked whether in fact Der Fremde might not have been an even more radical work had Camus openly addressed the question of sexuality and not apparently avoided it. ${ }^{214}$ In Winterreise, Roth seeks answers to the psychological, moral, and aesthetic questions which he believed Camus's portrayal of the sexual relationship had left open.

In the relationships between men and women portrayed in Der große Horizont and Ein neuer Morgen, the theme of separation ('Trennung') is emphasised. Haid is left by his wife and Christine. Patricia leaves Weininger. Dalton, whom Weininger admires, leaves both his wife and Patricia. In Winterreise, Roth decided to follow the polarity established by Dalton and have his central male character leave the woman. There are obvious autobiographical links to Roth's own separation and to later relationships. To pursue them adds nothing relevant to the present study. The theme of separation and the guilt associated with it, however, are clearly important to Roth. In a comment made on the pattern of the relationships running through his novel, Roth lightheartedly observed that in Winterreise Nagl takes 'revenge' for the way Haid and Weininger are left by the women they love. In the following novel, Der stille Ozean, Ascher 'pays' for what Nagl has done when Ascher's wife demands a divorce (Interview 1).

In their earlier association, neither Anna nor Nagl has been strictly honest or sincere. They have hurt each other and Nagl acknowledges this: 'Er gönnte ihr ihre Verletzung. Auch er war verletzt gewesen' (p. 21). He finds particularly hurtful the fact that she has deceived him by entering into brief and superficial affairs rather than actually falling in love with another man and leaving him for good. At the same time, he must face the fact that the way Anna has lied to him and slept with other men has increased rather than diminished his desire for her. For her part, Anna experiences no guilt about these affairs because they afterwards strike her as 'bedeutungslos' (p. 62). Anna explains to Nagl why this is so in a key passage in Chapter 17. She had struggled against her real attraction to Nagl because she felt that at heart he was indifferent to her: 'Du warst in Gedanken früher immer woanders ... Es war dir egal, was ich gemacht habe, du warst unabhängig von mir' (p. 61). She sought to escape her dependence on him in other relationships but discovered in her anxiety that he should not find out, that she loved him too much to leave him. Nagl recognises that he has been at pains to keep her at a certain distance, to show her that she has no right to possess him. He recognises his own easily wounded vanity in which feelings of indifference mingle with his reluctance to give up a woman

${ }^{214} \mathrm{It}$ is interesting that in La Mort heureuse (1936-38), which is amongst other things, a first sketch of L'Étranger, Camus treats Meursault's sexuality somewhat more explicity than in the later novel. 
he finds so attractive, a woman whose imagined innocence is contradicted by the thought of the other men she has slept with. Nagl admits to himself that Anna is a better person than he is: 'Er war schwerfälliger, empfindlicher, und eitler als sie. Vor allem war sie großzügiger als er' (p. 62).

Conservative critics ${ }^{215}$ have tended to dismiss Nagl as an emotionally shallow, narcissistic personality who drags Anna from city to city, reducing her to an almost mute but convenient sex-object. What this view overlooks is that there is in the relationship between Nagl and Anna a desperate and despairing form of love. Anna is not simply the long-suffering, essentially innocent victim of Nagl's inability to form a lasting emotional attachment, but a companion whose own complex emotions do not allow her to accept easily the strength of her affection for Nagl. In view of their past relationship, Anna's willingness to accompany him to Italy at such short notice had initially surprised him. He is delighted when she accepts. Neither at the outset, nor later on in Italy, is Nagl entirely indifferent to the way Anna reacts to him. He is caught in a paradox of conflicting emotions. He has always sought to be 'in love' and, at the same time to escape the vulnerability loving someone involves:

Immer hatte er das Gefühl zu lieben gesucht. Immer hatte er es erfahren als etwas, das ihn veränderte, das ihn mit Glücksüberschwängen überfiel und gleichzeitig verzweifeln ließ. Er war so sicher, wenn er liebte, daß er sich alles zutraute, zugleich aber war er der lächerlichste Mensch und litt. ... er spürte auch, daß er von ihr abhängig war. Er wollte sie nicht verlieren. Wenn es darauf ankam, würde er alles tun, daß sie bei ihm bliebe. Er mochte ihre Fröhlichkeit und Wärme und ihre Leidenschaft. Er mochte, daß sie sich von ihm gekränkt fühlte und eifersüchtig war. Und im Grunde mochte er, daß sie unberechenbar war und daß er durch sie erfahren hatte, daß es keine Unschuld gab (p. 149 and pp. 152-153).

It would be wrong to say that Anna is prepared for everything that follows, but her admission that she has deceived $\mathrm{Nagl}$ and her readiness to conceal from him her thoughts about and behaviour towards other men make it impossible to insist on her innocence. The difference between them is that Anna is more honest and courageous than Nagl with regard to her desires and emotions. She expresses affection more openly than he does and is not afraid to admit to her

${ }^{215}$ See, for example, Heinz Beckmann, 'Ein Mann fällt aus der Welt', Rheinischer Merkur, 24 March 1978: 'Derweilen bleibt Anna ein Anhängsel des Herrn Nagl, sozusagen eine Wärmeflasche zu beliebigem Gebrauch', or Hilke Prillmann, 'Süchtig nach Sehnsucht', Welt am Sonntag (Berlin), 12 March 1978: 'Wir erfahren von Annas schönem Hintern, Haaren und Brüsten, nur was in ihrem Hirn vorgeht, scheint nicht der Mitteilung wert ... Seine Neigung zu Anna ist ebenso "wertlos" für ihn wie alles andere außerhalb seiner Person'. 
deceptions and that she has sometimes used men for no more than sexual diversion. Nagl, on the other hand, has difficulty accepting such behaviour in himself and to protect his shakier self-esteem feigns a loyalty he has not in fact honoured. The recognition of this pattern increases the love he feels for Anna: 'Auch er machte es nicht anders. Er liebte sie auf eine neue Weise. Er spürte sich noch stärker zu ihr hingezogen, er mißtraute ihr, aber er erkannte auch Eigenschaften an ihr, die er früher übersehen hatte. Sie war mutiger als er und ehrlicher' (p. 151). The result is that for Nagl love necessarily seems to involve mutual deception: 'Die Liebe war für ihn jetzt ein Betrügen und ein Betrogenwerden, und wenn er liebte, mußte er sich dazu bekennen, auch wenn er es sich niemals zugeben würde' (p. 152). When Anna finally decides to travel back to Austria from Venice without Nagl, she does so in the knowledge that his emotional dependence on her is such that if she stays, he will not be able to resolve his feelings for her: 'Anna weinte und sagte, sie habe Abschied von ihm genommen, gestern und am Morgen. Wenn sie bei ihm sei, komme er nicht zu sich' (p. 168). At the station, Nagl is about to tell her that he will come back, but at that moment the train moves off. The leave-taking is not easy for $\mathrm{Nagl}$ and when Anna has gone, he feels intensely the pain of separation: 'Er spürte plötzlich körperlich, daß Anna nicht neben ihm war, und ein Würgen stieg in seine Kehle' (p. 170). It is not primarily out of lust that he later sleeps with the older Swedish woman he has pursued through the streets, but out of the need for human contact to overcome the sense of desolation he feels at being alone in a strange city with no idea what his next move will be. It is not because he has no love for Anna that he does not return to Austria with her. It is simply that his need to find himself is urgent and overpowering.

Roth's answer to the question of the relationship between sexuality and despair was not to break off the clear, detached narrative description of Winterreise at the moment of intimacy but to portray without squeamishness or prurience the varying forms of sexual behaviour through which Nagl and Anna express their feelings for themselves and one another. The result shocked some critics and was praised by others. Responses in the media ranged from an accusation that Roth had breached the principles of good taste and included sexually explicit scenes for their own sake, to unqualified admiration for the way Winterreise conveys the intense but restrained emotional pain felt by Nagl and Anna without lapsing into 'kitschige Sentimentalität' or 'exhibitionistische Drastik' ${ }^{216}$ The balance of critical opinion over Roth's unswerving portrayal of sexuality in the novel is positive. Roth succeeds in establishing a psychologically and aesthetically convincing link between despair and the simultaneous expression in the sexual act of pain and the desire to obtain release from the oppressive sense of self by reaching out to the other. There are

${ }^{216}$ Rolf Michaelis, “Aus der Erde gefallen: Gerhard Roths Roman "Winterreise", Die Zeit, 7 April 1978. 
scenes of intimacy between Nagl and Anna which have the power to shock the reader, but, like the refusal of Meursault in Der Fremde to display any sign of grief at his mother's funeral, the shock lies in their veracity. Against a background in which sexually explicit material of all kinds was already widely available in print and elsewhere, Roth's achievement in creating an authentic image of a sexual relationship is all the more significant. Amongst the Graz authors, it is Roth who has dealt most openly with sexual matters. It is arguable that readers of 'Grazer Literatur' will feel that this aspect of their lives is better expressed and understood by Roth than by any of the other 'Grazer', including Handke, whose treatment of sex is veiled in a sometimes narcissistic remoteness.

The sexual episodes in Winterreise are interwoven with the novel's other incidents and themes in a subtle and contrapunctal manner. The frequency of the spontaneous and sometimes drunken couplings in which Nagl and Anna engage is entirely in harmony with the bouts of sightseeing, eating, and drinking in which they also indulge. Nagl is restless, constantly seeking new stimuli and diversions. Anna follows him in the hope that there will be an end to his flight. He perceives his surroundings intensely and seeks respite from the world he sees and from himself in alcohol: 'Er erlebte die Augenblicke so stark, aber er erlebte sie nicht mit klarem Kopf. Alles ging ihm durcheinander. Es ekelte ihn jetzt davor, zurückzudenken. Er wollte auch nicht daran denken, was kommen würde. ... Er fühlte sich erlöst, wenn er spürte, wie der Alkohol wirkte. Der schönste Moment war, wenn ein großer Finger ihn im Kopf berührte und ihn benommen machte' (p. 53 and p. 54). A haze of intoxication surrounds much of Nagl's journey through Italy and this same need for intoxication flows on into the expression of an uninhibited and sometimes tormented sensuality. $\mathrm{Nagl}$ and Anna arouse one another to the point where they loose self-control. Acts of self-gratification intermingle with genuine expressions of tenderness. In deciding how he would present the sexual act in Winterreise, Roth noticed how the facial expression of someone in pain is similar in many ways to that of someone experiencing intense pleasure. In the idea that expressions of pleasure and pain are separated from one another only by a thin barrier, he found the clue he needed to link the almost compulsive pursuit of sexual pleasure with the pain of despair:

Man sieht am Gesicht eines Menschen, der Schmerzen hat, ähnliche Ausdrücke wie ein Mensch, der Lust empfindet. D. h., daß Verzweiflung und Lust durch eine ziemlich dunne Barriere, so wie $\mathrm{Haß}$ und Liebe, voneinander getrennt sind. Sie sind gegensätzliche Pole aber trotzdem nicht sehr weit auseinander (Interview 1). 
Nagl's inner torment at the crumbling away of all fixed reference points is such that he plunges almost gladly into an abyss of self-abasement:

In der Verzweiflung war er zu Dingen fähig, die er sonst nie wagte. Es waren Dinge, die ihm entsprachen. Er war mutiger und ehrlicher. Die Scham fiel von ihm ab. In der Verzweiflung gab es eine Selbsterniedrigung, die wie ein angenehmer Schauer durch den Körper rieselte (p. 139).

In terms of Freud's argument about the role of work, it is interesting to note that Nagl's experience of the degradation of the value of the work he performs and the lack of an adequate 'Ersatzbefriedigung' in the form of an intellectual interest or artistic pursuit such as had helped to sustain Haid and Weininger, causes him to fall heavily back on one of the third and most basic of the three 'great diversions', the intoxicant alcohol, as well as experiencing an increased desire for sexual release. The matter-of-fact expression of sexuality and the emphasis on the physicality of the sexual act is appropriate to Nagl and Anna as representatives of the post-war generation for whom the 'sexual revolution' of the 1960s was a reality. It is also appropriate to a relationship in which both emotion and reason are so disturbed that sex becomes the last and perhaps most desperate form of communication: 'Eine Liebe, die keine Sprache findet, außer im gemeinsamen Verstummen des Rauschs, außer in der - durch Gesten animalischer Zärtlichkeit gemilderten - Vereinzelung sexueller Lust, außer in plötzlichen Weinkrämpfen'. ${ }^{217}$ Roth was fully aware that the portrayal of sex in Winterreise would appear both 'drastisch' und 'mechanisch' but he realised that no other treatment was adequate to express Nagl's state of mind. For Nagl the sexual act is not utterly devoid of procreative or romantic connotations. ${ }^{218}$ The social and family structures on which these interpretations depend have, however, all but entirely disintegrated for him because they too derive much of their legitimacy from the concept of meaningful work. Frequent surrender to the compulsion of the sexual drive, like Nagl's almost daily resort to alcohol, provides at best only a temporary refuge from the pain of existence. Nagl has seen through the hypocrisy of his earlier romantic posturing. He experiences no shame where sex is concerned and can no longer pretend otherwise. The bluntness of Nagl's sexual behaviour towards Anna is unpalatable to some readers but it is essential to Roth's purpose in writing the novel. Roth's desire to be honest in his portrayal of despair leads him to depict behaviour which is not necessarily socially acceptable. The result is an authenticity in the character of Nagl which is both impressive and disturbing.

\footnotetext{
${ }^{217}$ Rolf Michaelis, 'Aus der Erde gefallen'.

${ }^{218}$ See, for example, p. 34: 'Er dachte an Anna, wie sie ihn nackt auf dem Bett umarmt hatte, ihre weiße Haut, an das Leben, das sie geben konnte, an eine durchsichtige Fruchtblase, in der ein Embryomensch sich bewegte'.
} 
The fragile and partial nature of the values, ideologies and interpretations which provide an anchor of security within the conventional life-experience is also reflected in the intensity of Nagl's perception of the world about him. Like einstein, Haid, and Weininger before him, Nagl is also an acute observer of the details of everyday life, with a strong bias towards the visual. He is beset, if not quite overwhelmed like his predecessors, by the constant flow of perceptions and impressions which fleetingly command his attention but do not, and from a human perspective probably cannot, cohere into a meaningful whole. Nagl is not engulfed like einstein, nor is he as subject to hallucinatory moments as Haid, but he is often riveted or disturbed by the associations he makes with the fragments of the life-world which impinge on his consciousness. Roth's disavowal of any symbolism in Winterreise makes it appropriate to approach Nagl's perceptions and observations phenomenologically, that is, as instances of an impersonal life-process which manifestly exists but resists any final interpretation. The phenomena which Nagl perceives affect him emotionally and intellectually in so far as he reads them subjectively as affirmations of the life within him or as intimations of a death he knows he cannot avoid. As in Roth's earlier works, it is the accumulation of such perceptual moments which brings a strong sense of vitality and concreteness to the narrative. The same 'neurotische Wahrheitsliebe' 219 which underlies Roth's descriptive technique in Horizont, Morgen, and is employed later in Der stille Ozean, drove him to take several hundred colour transparencies in Italy as 'Fotonotizen' for key scenes in Winterreise. The forward impetus of this otherwise reflective narrative is largely provided by the steady accretion of these 'Momentaufnahmen'.

In the same streets, marketplaces, restaurants, bars, hotels, museums and other tourist spots which provide the common backdrop to any winter tourist in Italy's larger cities, Nagl is confronted by the daily activities of ordinary people in whose lives he is only a spectator, and by the peculiarities of their physical setting. The wider setting of sea, sky, and weather is also never long out of view. True to the perspective Roth wished to capture in the original transparencies, the resulting descriptive images express an intensifying sense of alienation. ${ }^{220}$ From the early description of the market halls in Naples to the depiction of the interior of the Doge's Palace in Venice, Roth sets forth sharply focused images of a world in which light and dark, life and death, inextricably intertwine: ${ }^{219}$ Kurt Wimmer, 'Keine Sehnsucht nach Stillstand' (Interview), Kleine Zeitung, 5 June
1977 .

${ }^{220}$ 'Ich wollte das Fremdsein, das sich immer mehr Entfremden von Wahrnehmungen fotografisch festhalten'. G. R., 'Fotografien zu "Winterreise", protokolle, 2 (1978), pp. $72-84$ (p. 72 ). Also in $M B M$, pp. 138-151 (p. 138). 
In blauen Blechgefäßen krabbelten Langusten durch Wasser, in das mit durchsichtigen Nylonschläuchen Luft gepumpt wurde, auf Tischen waren tote Fische - Sardinen, Aale, Schollen, Makrelen, Polypen mit goldenen Augen, Rochen - und andere ausgebreitet, die er noch nie gesehen hatte, mit bizarren Köpfen, Stacheln, und großen Mäulern, rote und gesprenkelte zwischen grauen, toten Tintenfischen, die wie Gedärme aussahen. In einer Schüssel lagen große silberne Fische und glitzerten und blinkten in der Sonne. Die Geschäfte dahinter waren blau und ohne Türen, und die Männer trugen Gummischürzen und sahen aus wie Mörder (pp. 34-35).

Dann trieb es ihn weiter an den schwarzen Tischen mit den Intarsien aus bunten Vögeln, Blumen, Trauben, Blättern und Tieren vorbei, an den teerschwarzen Bildern von Hieronymus Bosch, den Kommoden mit Einlegearbeiten aus Rosenholz und Perlmutt, den schwarzen Balkendecken mit Blumengirlanden, den abgewetzten, kardinalroten Samtsesseln mit goldenen Blattornamenten, den bleigerahmten, durchsichtigen Butzenscheiben, den Wänden aus tabakbraunem und vergoldetem Holz, den Tintorettos und Veroneses an den Decken, dem großen Guckloch an einer Tür, den grünen, goldenen und blauen Wanduhren, den riesigen goldenen, an den Wänden befestigten Kerzenleuchtern, den Bänken mit den unterteilten Sitzen und Armlehnen, den nach altem Holz riechenden Sälen vorbei bis zu einem Balkon, von dem aus er auf das glitzernde Meer und San Giorgio Maggiore und La Giudecca sah. Es war ein schöner, weiter Blick, als hätte ein Mensch diesen Balkon gebaut, um alle Kräfte zu sammeln und von hier aus in das Universum zu fliegen. ... Als er wenig später in die Gefängnisse - niedrige mit doppelten Eisengittern abgesicherte Zellen - gekrochen war und den Stein unter den Gittern gesehen hatte, der blankgescheuert war wie Elfenbein und in den die Namen und Gesichter der Häftlinge: Pirico Camillo und Francesco Sforsa, geritzt waren, als er die eisernen Ringe an den Wänden sah und die Daten las, spürte er wieder Verlassenheit und Einsamkeit (pp. 186-187).

There is a natural progression from the impressions Nagl gathers of the external world to the internal processes of his subconscious, to the associations and memories which link the sense of his personal existence and its final extinction to the life and death he observes in the world around him. The 'es' by which he feels driven is life itself, the same force to which he felt the urge to surrender at the opening of Winterreise as he prepared to set out on his journey: "Vielleicht", dachte er plötzlich, "war es wirklich das Gescheiteste, sich dem Leben anzuvertrauen, wie man sich dem Tod anvertraut, auch wenn die Nähe zum Leben eine Nähe zu den Schrecken des Lebens bedeutet"' (pp. 9-10). The fact that Nagl appears locked within the role of the sometimes 
emotionally distant, sometimes compassionate observer, who 'sees' but cannot actively participate in life, is the measure of his despair over the loss of meaning which he experiences most acutely within the social sphere of his existence. It is not the case that Nagl regards the whole of life as meaningless: on the contrary, he is awed by the complexity and vastness of the universe and its life-forms. He remains isolated because the society in which he has lived and worked until now will not admit to the essentially mysterious nature of life as he has come to apprehend it, and thus tries to conceal the emptiness behind the outward show of meaningful activity. It is the world of consensus reality with its undertones of conformism, and cowardly conspiracy to keep up appearances which Nagl has 'fallen out of'. His resulting melancholy is heightened by the illusory nature of seeing itself: what appears wonderful and mysterious from a distance, overfamiliarity or a shift of emotion can break up into dull or repetitive detail:

Das Gewöhnlichste und Normalste, das Alltäglichste, das sich tausendfach wiederholte, so daß er es gar nicht mehr wahrnahm, war die Erde. Von weitem war sie das, was ihm wie seine Vorstellung vom Leben vorkam: etwas Wunderbares, Geheimnisvolles. Aber je näher er an dieses Leben herankam, desto mehr löste es sich auf in Einzelheiten, in Kleines, in der Wiederholung. Das Leben war ein Dahinleben, so wie die Erde nichts besonderes war im Universum, eine Belanglosigkeit (p. 15).

The illusory nature of surface appearances is a common theme in 'Grazer Literatur'. But the opposite also holds true: a detail, the gesture of a moment, can restore the sense of wonder: 'Anna streichelte ihm über das Haar, und er griff nach ihrer Hand. Auch wenn er den Eindruck hatte, daß nichts mit ihm etwas zu tun hatte, so spürte er doch, wie reich das Leben war' (p. 96). As Ria Endres has noted: ' $\mathrm{Da}$ diese Welt eigentlich schön sein könnte, daß es möglich ist, schöne Sätze zu formulieren, macht die ganze Sache nur noch hoffnungsloser'. ${ }^{221}$

It is Nagl's desperate need to 'see', to reach the truth about himself and the world which compels him to look so intensely at the world around him: 'während er litt, zwang er sich alles zu sehen' (p. 178). It is this compulsion to observe and probe reality and the experience of the pain and isolation that accompanies such acts of seeing which Nagl shares with the figures of Roth's early experimental works. (See p. 152). In Winterreise, Roth brings this suffering and displacement into historical and philosophical perspective.

The ending of Winterreise, Nagl's decision to fly from Venice to the 'ewiges Eis' of Alaska, struck Greiner, amongst others, as a 'komisch-irrealer

${ }^{221}$ R. E., 'Jenseits der Verzweiflung: Melancholische Prosa ohne modische Effekte', Deutsche Zeitung, 31 March 1978. 
Schluß'. ${ }^{222}$ Initially Roth conceived of two possible endings, 'die Möglichkeiten des Untertauchens und des Selbstmordes' (Interview 1). Both were ideas which had intrigued him personally for some time. The circumstances under which he finally wrote the novel were difficult in the extreme. Early in 1977, Roth resigned from his position at the Graz data centre. He was in poor health. He was soon diagnosed as suffering from a severe heart condition and was advised by his doctor to move to the country to recuperate. He found a house for rent near the village of St. Ulrich in Südsteiermark and moved there in the Autumn of 1977 to work on Winterreise. After a series of difficulties and disagreements with his Suhrkamp publisher, Siegfried Unseld, Roth broke his contract and changed to S. Fischer Verlag. He was encouraged to make this move by the fact that the editor of his early work, Thomas Beckermann, had recently taken a position there as chief editor of the new publishing programme, 'Collection S. Fischer', which was devoted to publishing new German literature. Unseld fought hard to retain the rights to Winterreise, even offering Roth a six-month (DM 10,000) advance, but the author's recent experiences with Suhrkamp over the production of his drama Sehnsucht ${ }^{223}$ led him to reject the offer and return the money, although he was badly in need of funds at the time. The move finally proved to be to Roth's advantage. He became the first author enlisted in S. Fischer's new programme and received the distinction of being granted a full contract, 'den sonst nur Leute wie Schnitzler und Hofmannsthal bekommen haben'. ${ }^{224}$

The winter proved harsh and the house was run down and poorly heated. The separation from his wife became final. It was a dark, bleak period in Roth's life. His illness was serious enough that he was forced to confront in earnest the 'Todesangst' from which he had suffered periodically since childhood when he had tried to counter his fear by imagining himself lying already dead on his bed. Faced with the choice of allowing Nagl to flee to Alaska or commit suicide, he preferred the former 'weil ich das mit Sicherheit auch zuerst probiere' (Interview 1). For Roth, the alternative of suicide was equally plausible as an ending but, ill as he was, it was not a theme he felt inclined to dwell on. In the past he had thought about taking his own life on a number of occasions. In Der große Horizont, Haid thinks briefly of suicide, but it is Ascher, the protagonist of Der stille Ozean, who eventually shoots himself in Landläufiger Tod.

${ }^{222}$ U. G., 'Das Gespenst der Freiheit', Frankfurter Allgemeine Zeitung, 11 March 1978. Reprinted in U. G., Der Tod des Nachsommers, pp. 168-172, (p. 171).

${ }^{223}$ Sehnsucht premiered simultaneously in Graz and Basel on 8 October 1977. The present study cannot for reasons of length include an examination of this play which deserves separate analysis in the context of Roth's development as a dramatist.

${ }^{224}$ Roth: anon, 'Roth wechselt Verlag', profil, 18 October 1977. 
The melodramatic touch to the final scene of Winterreise is deliberate. In Nagl's departure for the icy wastes of Alaska, Roth recalls the ending of a Humphrey Bogart film in which the hero flees with his mistress into a snowy night and a scene from the Ken Russell version of the D. H. Lawrence story, Women in Love, in which a male figure walks out into the mountain snow. The ending emphasises the notion of escape, the possibility of disappearing into an unknown territory and beginning a new life, far removed from the scenes of a former, untenable mode of existence. This conclusion to the novel is not necessarily a negative one. Just before he decides on the journey to Alaska, $\mathrm{Nagl}$ has observed the figure of a lonely old man bringing scraps of food to a woman who feeds it to stray cats in the street: "Als der Alte sah, daß alle Katzen fraßen, ging er gebückt allein und langsam in die Dunkelheit, in der die großen Schiffe lagen' (p. 192). In contrast to the darkness and desolation of this scene, the thought of the arctic ice brings with it light and colour: 'Das Eis war blau' (p. 192).

Nagl's plight expresses Roth's conviction that, in Western society at least, to try to live authentically according to one's deepest impulses, is fraught with difficulty and the pain of isolation: 'Der Mensch steht mit seiner grundsätzlichen Existenz allein'. ${ }^{225} \mathrm{Nagl}$ does not willingly or misanthropically turn his back on his fellow human beings. This shows most clearly in the visit to Vesuvius. The landscape of lava and snow is as desolate and remote from human habitation as the surface of the moon: 'Es kam Nagl vor, als müßte jemand sich so die Welt vorstellen, wenn er sie zum ersten Mal im Raum sah. Er hatte gedacht, aus der Welt gefallen zu sein, und jetzt war ihm, als erlebte er es wirklich, wie es ist, wenn man aus der Welt gefallen ist. Er empfand Sehnsucht nach Menschen' (p. 74). The longing for simple human contact occurs again shortly afterwards as they drive past a pleasant waterfront park on the way back to Naples (p. 75). Nagl associates the sight of people strolling in the park with the Sunday morning walks he and his brother used to take with his grandfather in Graz. In the same way his grandfather accepted suffering as the price he had to pay for living, so Nagl must now accept the isolation which his search for himself entails. Looking into the crater of Vesuvius, Nagl has confronted the abyss. Temporarily he turns back, clinging for a while longer to Anna, taking leave of her, then briefly seeking comfort from the Swedish woman he meets in Venice before he summons the courage to break finally with his former existence and seek a new dimension of experience in Alaska.

The strength of Winterreise hinges on the complex, at times obsessive, but always credibly human character of Nagl. What remains at the close of the narrative is a convincing portrait of a man probing the very limits of his existence. Critics who claim to detect a lack of depth in the characterisation of

${ }^{225}$ Roth interviewed ḅy Alois Kurzmann, Harlekijn, No. 2 (1980), pp. 5-9 (p. 8). 
Winterreise overlook the fact that Roth's narrative technique is not conventional and does not permit a naive distinction between the elements of 'character' and 'content'. There is nothing in the text which is incidental to the process of characterisation. The separation which can be made in a narrative of conventional realism between the language contributing to the formation of character and the descriptions which are dedicated to the creation of environment, is not appropriate to Winterreise. In Winterreise, the presentation of the central character's perceptions - material which might wrongly be regarded as pertaining only to the setting - is an essential part of the process of characterisation. Although the narrative tone is seemingly neutral and objective, it is the product of a third-person narrative voice which is subjective in the extreme. Through what Nagl sees around him, the reader gains access to the workings of Nagl's consciousness. Nagl's indifference is only apparent. It is not the product of a coldness or impersonality in his nature as some reviewers assumed, ${ }^{226}$ but of his intense concentration on what is occurring in and around him. There is a passionate search for meaning behind the way Nagl constantly registers and probes his surroundings. For all its winter setting, the novel is surprisingly rich in the colours, forms, and textures of the world. Roth leads the reader through a stream of bright, almost cinematic images: ' $\mathrm{Er}$ ging durch den marmorschimmernden Dom, goldene Blätter und Blumen verzierten die Bronzesäulen des großen Altars, und die Kuppel über dem roten Baldachin schien ein riesiges Fenster in das violette All zu sein. Nagl sah an goldenen Sternen vorbei immer weiter, in schwindelerregende Höhen' (p. 99).

The problem with Nagl's perspective on events, if indeed it is a problem and not an unavoidable fact of human consciousness, is the 'Ichbezogenheit' he shares with Roth's earlier fictional creations. In Venice, Nagl registers for the first time, how ego-centric his perception has become. In Horizont, Haid was the victim of a painful self-consciousness which caused him to behave awkwardly: 'immer hatte er mit einer unerträglichen Intensität sich selbst gespürt' (p. 70). Nagl's sense of identity is stronger than that of Haid whose selfobsession is more narcissistic. What Nagl experiences is a detachment which would appear to signal a positive loosening of the bonds of the everyday ego. He has the sensation of watching himself as if from a short distance. In the context in which it occurs, there is nothing pathological about this. It does not cause him panic, anxiety, or revulsion as it does in the case of Kalb or Haid earlier, or in the case of other literary figures like Roquentin in Sartre's novel La Nausée (1938). Nagl accepts this self-observation, together with the

\footnotetext{
${ }^{226}$ See, for example, Hans Haider, 'Larmoyant-brutale Ohnmacht', Die Presse, 8 February 1978, who describes Nagl as a 'Gefühlszwerg' who 'pflegt seine Leiden mit Brutalität', or Kurt Lothar Tank, 'Weg in ewiges Eis: Das Protokoll einer Selbstaufgabe', Deutsches Allgemeines Sonntagsblatt, 26 March 1978: 'weitgehend emotionslos, ein Leben ohne Gefühle'.
} 
sensation of déja-vu which sometimes accompanies it, comparatively calmly as a new, if unexpected, facet of his experience:

Seit er mit dem Zug weggefahren war, war etwas geschehen, das er zwar erlebte, das ihm aber nicht bewußt geworden war: Er sah dauernd sich selbst. Manchmal sah er sich von oben, er sah sich laufen, gehen, stehen, er sah sich Anna umarmen, oder es war ihm, als könnte er sich aus nächster Nähe beobachten. Es störte ihn nicht. Er sah Speichel aus seinem Mund rinnen und er sah sich am Rand des Vesuv stehen und in den Krater blicken ... Und noch etwas war ihm aufgefallen: Das Gefühl, etwas schon erlebt zu haben, die Überzeugung, das Wissen darum, war zum ersten Mal in Neapel in der Hafenstraße aufgetaucht. Aber es hatte sich immer wieder eingestellt, und er hatte es immer wieder zur Seite geschoben, wie um sich zu schützen (p. 128).

Behind Nagl's calm acceptance of his displacement, the emotional pain it induces still persists. Because Nagl is in no obvious material need, because he is apparently turning his back on a secure existence, this pain might seem insignificant, a luxury of intellectual reflection. But it is the hasty or insensitive reader who mistakes the neutral tone of the narrative for a lack of feeling Nagl's emotions are in a turmoil from which he seeks refuge in alcohol and sex. He has reached a state of overload in which his capacity for emotional response is impaired but is certainly not absent. Amongst the critics who have approached the novel, Ulrich Greiner grasps the point most keenly when he says of the language of Winterreise: 'Sie ist von jener sachlichen Kühle, die nicht aus Gelassenheit kommt, sondern aus gezügeltem Schmerz'. ${ }^{227}$ The 'ewiges Eis' for which Nagl departs should be read not as a sign of emotional coldness, but as a metaphor of Nagl's need for release from the pain which he feels.

Roth took a decided risk in publishing Winterreise. The novel could easily have ruined the reputation he had built up. Working firmly within the novel form, he could no longer take refuge under the cloak of the avant-garde. His treatment of Nagl's relationship with Anna was a provocation to conservative and left-wing critics alike. The definite line he had chosen with regard to the meaning of work and sexuality exposed him to a potential broadside attack from ideologues of all persuasions. Winterreise indeed gave rise to a storm of critical opinion but proved well able to weather the assaults made on it. Most importantly perhaps for Roth, the novel met with a positive reception by many readers of his own generation. Critical outrage at the novel's imagined sexual excesses only tended to distract the attention of some reviewers from Roth's success in creating a character, who no matter how extreme his emotional state,

${ }^{227}$ U. G., 'Das Gespenst der Freiheit', (= Der Tod des Nachsommers, p. 169). 
always remains a believable, sympathetic human being and a precise observer of the world around him. The novel is not without its faults, including a few grammatically awkward constructions which irritated Jörg Drews in particular. ${ }^{228}$ In terms of Roth's positive achievements in Winterreise, such failings are minor. More astute West German critics recognised the novel's considerable literary worth. In September 1978, Winterreise was nominated for and won the first ever 'Preis des Literaturmagazins des Südwestfunks'. The twentyseven literary critics on the jury, which included Walter Jens, awarded the prize to Roth's novel, 'weil es dem Autor gelungen ist, mit großem literarischem Ernst am Beispiel einer persönlichen Krise die Erfahrung der Fremdheit unter den Menschen darzustellen' ${ }^{229}$ Instead of the usual 3,000 copy first-edition granted to Roth's earlier works by Suhrkamp, 8,000 copies of Winterreise were launched on the book market by S. Fischer. Before the end of the year, a second edition appeared, each copy with a paper banner announcing that Roth had won the Suidwestfunk literary prize. Early in 1979, Roth was awarded a nine-month literary fellowship by the City of Hamburg, a distinction he shared that year with fellow Austrian author Peter Rosei.

Winterreise exemplifies in a positive and mature form the literary impulses and strategies characteristic of 'Grazer Literatur'. As a paradigm example of the new Austrian literature, it is as rewarding to examine in depth as Handke's Wunschloses Unglück. Although the language of Winterreise may not be deemed as elegant as that of Wunschloses Unglück, Roth's novel is equal in its power to convey against the background of recent Austrian history, experiences, emotions and reflections which, for authors of Roth's generation, represent an important step in the process of coming to terms with life in the Second Republic. Through the story of Nagl's grandfather, Roth addresses issues which are specifically Austrian. At the same time, he avoids any hint of the parochialism which the Graz authors found so repugnant and limiting. In the central themes of work, sexuality and the causes of despair, Roth introduces ideas of universal significance which make the work readily accessible to an international audience. ${ }^{230}$ From the point of view of literary technique, Winterreise skilfully combines the montage of perceptual fragments with a more traditional approach to narrative. In the face of the work itself, the objection from the pure experimentalist camp that a successful experiment is no longer truly experimental, appears trivial. Winterreise is free of conformist tendencies.

\footnotetext{
${ }^{228}$ See J. D., 'Nun ist die Welt so trübe: Gerhard Roths neuer Roman "Winterreise"', Süddeutsche Zeitung, 15 April 1978.

${ }^{229}$ Anon., 'Neuer Literaturpreis an Gerhard Roth', Frankfurter Allgemeine Zeitung, 4 September 1978.

${ }^{230}$ Winterreise is the first of Roth's novels to be translated into English: Winterreise, translated by Joachim Neugroschl, (New York, 1980). The English text is unfortunately inferior to the German original in a number of instances.
} 
Fundamental social values are called into question. The novel remains faithful to the anarchic, oppositional role ascribed to 'Grazer Literatur' without losing sight of the need for communicability. Finally, in terms of the Austrian tradition of linguistic self-consciousness, Winterreise is a work in which the author demonstrates a sharp critical awareness of language and the sometimes unbearable limitations we impose on ourselves and others through our unreflective, habitual descriptions of the life in and around us. 